@

SHII

A14

LIBRARY

ANNEX

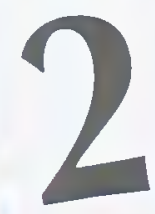

$x^{2}$ 
SH 11.A14 Cornell University Library

The commercial fisheries [of the Hawaila

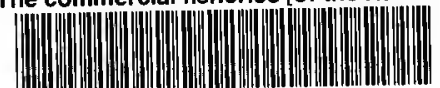

31924003261801 


\title{
THE AQUATIC RESOURCES OF THE HAWAIIAN ISLANDS.
}

\author{
$\mathbf{B Y}$ \\ DAVID STARR JORDAN \\ AND \\ BARTON WARREN EVERMANN.
}

Section III. THE COMMERCIAL FISHERIES.

BY

JOHN N. COBB.

Extracted from Bnlletin of the U, B. Ftsh Oommission for 1903 Part II, Pages 715 to 765.

Plates 102 to 106 .

ISSUED AUGUST 5, 1905

WASHINGTON :

GOVERNMENT PRINTING OFEICE.

1905 


\section{Cornell University Library}

The original of this book is in the Cornell University Library.

There are no known copyright restrictions in the United States on the use of the text.

http://www.archive.org/details/cu31924003261801 


\title{
THE AQUATIC RESOURCES OF THE HAWAIIAN ISLANDS.
}

\author{
BY \\ DAVID STARR JORDAN \\ AND \\ BARTON WARREN EVERMANN.
}

Section III. THE COMMERCIAL FISHERIES.

BY

JOHN N. COBB.

Extracted from Bnlletin of the U. S. Fish Commission for 1903, Part II, Pages 716 to 765. Pletes 102 to 106.

Issued August 5, 1905.

WASHINGTON :

GOVERNMENT PRINTING OFFICE.

1905 . 



\section{THE COMMERCIAL FISHERIES OF THE HAWAIIAN ISLANDS. \\ BY \\ JOHN N. COBB, \\ Agent of the United States Fish Commission.}






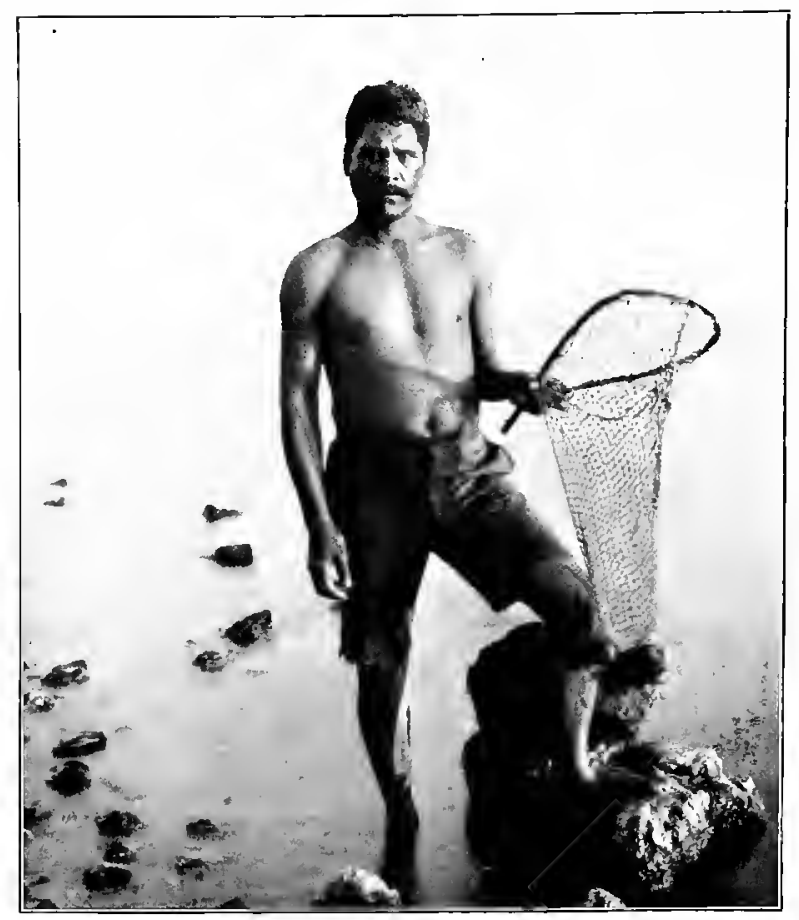

NATIVE FISHERMAN WITH DIP NET.

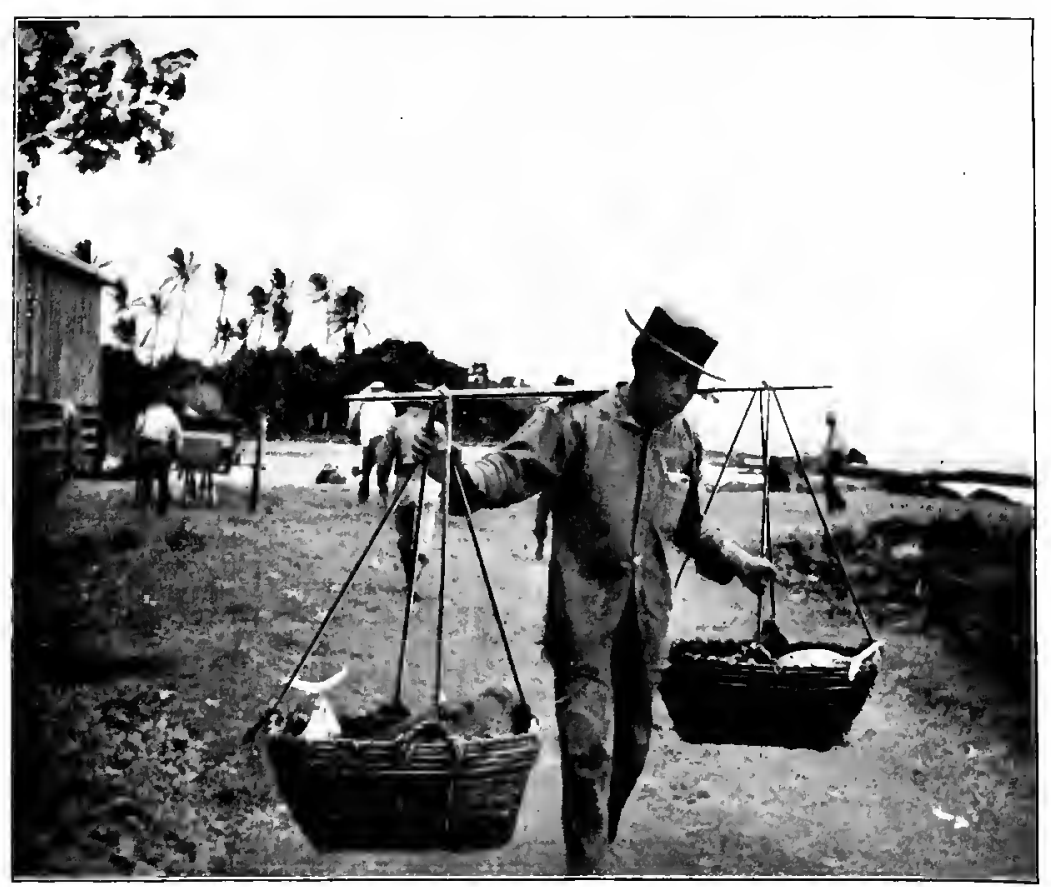

CARRYING FISH IN BASKETS. 


\title{
III. THE COMMERCIAL FISHERIES OF THE HAWAIIAN ISLANDS.
}

\author{
By John N. CовB, \\ Agent of the United States Fish Commission.
}

\section{INTRODUCTION.}

On May 1, 1901, the writer was detailed to accompany the party which was to make an investigation of the fishes and fisheries of the Hawaiian Islands under the direction of Dr. David Starr Jordan and Dr. Barton Warren Evermann, in order to make a thorough canvass of not only the present condition of the commercial fisheries of the islands, but also of their past history and "the changes in the methods, extent, and character of the fisheries in historic times, as shown by records or traditions, particularly since the coming of Americans, Europeans, and Asiatics." The history of fishery legislation and the possibility of improvements in the present laws were among the questions which received careful consideration.

These inquiries occupied a period of three months, during which all of the larger inhabited islands were visited. All available official and private clocuments, newspapers, and publications relating to the islands were perused, and oral statements were gathered from the older fishermen and other's conversant with the subjects in question.

Commercial fishing is prosecuted on the islands of Oahu, Hawaii, Maui, Molokai, Kauai, Lanai, and Niihau. It is also carried on about some of the suraller islands of the group, but by fishermen from those above named. The fisheries are of considerable importance now, and could easily be expanded if the proper efforts and attention were given to them.

At present but little deep-sea fishing is done, although this could be made a very profitable industry. Sone of the best grounds are off the coasts of Molokai, and quite a fleet of Japanese boats from Honolulu resort thither. They usually leave on Monday and return on Friday or Saturday.

At various places around the islands sponges of a fair quality have been picked up on the beaches, where they had been cast up by storms. The writer secured a few specimens at Oahu and Hawaii and found them of an inferior grade, but still marketable. It is probable that but few of the better quality of sponges would be washed ashore, as they would be too firmly attached to the bottom.

The bubonic plague broke out in Honolulu in December, 1899, and lasted several months, proving a serious detriment to the sale of fresh fishery products while it lasted, as many persons thought that the disease might be transmitted in this way. 


\section{FISHERMEN.}

Owing to their location between the continents of Asia and America, the islands have been securing lecruits from each direction as well as from the numerous islands to the south. Europe, too, has furnished immigrants, until at present the islands present quite a cosmopolitan appearance. An idea of the extent of this admixture may be gained from the fact that public notices in the fish markets and other places are usually printed in five languages-English, Hawaiian, Chinese, Japanese, and Poltuguese.

In numbers the native Hawaiian fishermen surpass all the others combined, but this is partly because so many women and children engage in the hand fisher'y for octopus, algre, etc., and theso have been counted in the total. Some of the natives are at the head of quite important fisheries, and for many years held a monopoly of the industry, but more recently the Japanese have been engaging in it in large numbers and now occupy second place. The natives fish spasmodically, as a rule, while the Japanese give to it their whole time and attention, and as a result are profiting much more. They are especially numerous on Oahu and Hawaii, most of them being engaged in deep-sea line fishing, which they virtually monopolize. Thes lave several companies at Honolulu, Lahaina, and Hilo, and in this way control certain fertnres of the fishing industry, thus enhancing the cost of the products to the general public.

Only six Americans bave a direct connection with the fisheries, and they principally as managers of the large fishery rights on Kauai and Maui. The few Chinese fishermen confine themselves to the fisheries immediately along the shores. A few years ago they began leasing the tish ponds still in use on most of the islands, and now have practically a monopoly of this part of the industry. They also quite gencrally control the selling of fish in the markets. A number of South Sea Islanders, mainly from the Gilbert, Caroline, and Marquesas islands, are engaged in fishing, principally at Honolulu and Lahaina. They are more industrious in this business than the natives and are quite expert. They are the principal users of fish baskets. The Portuguese are not largely engaged in fishing. The Italians have made some efforts in this pursuit, but none are now thus employed.

\section{LAY OF THE FISHERMEN.}

The native fishermen usually make an equal dirision of the fish taken, or of the proceeds, among all engaged in it. In a few instances they are hired and paid regular wages.

At Hilo, on Hawaii, in the gill-net and line fisheries the Japanese work on the following basis: The owner of the boat furnishes the lines, nets, etc., and takes 29 per cent of the gross proceeds. The balance is then divided equally among the owner and others who participate in the fishery. Should the owner not go out in the hoat he does not get anything in the final division.

In the seine fishery at. Hilo the owner of the boat and net receives from 30 to 35 per cent of the gross proceeds, this being regulated by the size of the net and hont, while the balance is divided equally among the fishermen, the owner, if he accompanies them, receiving his share with the rest. When the fishernien work on salar'y they receive $\$ 15$ per month, with their board and lodging. 
At Honolulu, among the Japanese fishermen, the owner of a boat used in the fisheries takes 15 per cent of the gross proceeds, the rest being divided equally among the fishermen. The owner of the boat supplies everything except food, and generally accompanies the boat and gets his regular share with the other's.

BOATS.

Canors.--The native Hawaiians in fishing use canoes exclusively. Some of these, particularly the older ones, are rery handsome in design and workmanship, the old-time native boat builders having been especially expert. The present generation has sadly deteriorated, however, and the canoes made now by natives rarely show very much skill.

The body of the canoe is usually hollowed out of the trunk of a koa tree (Acacia loa), which averages from 50 to 60 feet in height. Th is tree, formerly quite common, is now rather searee, owing to the cxcrssive denands made upon the supply for canoe building and other purposes. After the tree has been cut down and the branches stripped off, the trunk is cut to the desirect length and roughly hewn into shape, then bronght down to the shorr, where the tinal touches are given. After the body of the canoe is finished a rim about 6 inches in height is fastened to the upper part by means of wooden nails. The holei (Ochrosin sumbicensis), a tree from 6 to 19 feet in height, is preferred for this purpose, but the ahakea (Bobea elation), a tree 20 to 30 feet in height, is sometimes used.

Each canoe is fitted with an ontrigger, made by laying two long, slender poles, slightly curved at one end, across the canoe alsout one-fourth way from each end of the latter, and so arranged that on one side thry extend a few inches over the side, while on the other, where they are rurved, they run out from 6 to 8 feet. These poles are firmly lashed to the body of the canoe where they crosis it, with stout twine. A sapling about 12 feet long and 6 inches in diameter is then lashed to the under side of these poles near the extreme end;, lying parallel to the body of the canoe and extending slightly beyond the cross poles at each end. The wiliwili (Erythrinu momnserma), a tree 20 to 25 feet in height, is generally employed in constructing the outrigger, the object of which is to balance the canoe, which is very narrow. With ordinary (at $11^{\circ}$ it is almost impossible to capsize a canoe fitted with an ontrigger. The natives make long journeys in then, frequently in quite stormy weather.

An ordinare canoe for one person would be about 18 feet long and about 17 inches wide, while a three-seated canoe would arerage 33 feet in length and 21 inches in width.

The paddle has a long, slender handle, usually about 46 inches in length, with an oblong blade about 23 inches long hy $13 \frac{1}{2}$ inches wide. The wood of the paihi tree is frequently used, especially on Hawaii, in making the ordinary paddles, while the wood of the koaia (. Leacia Tomin) is grenerally used in the manufacture of the fincy ones.

The South Sea Islanders on the Hiswaiian Islands use a slightly different arrangement of the outrigger. At the onds of the cross poles short forlied sticks are lashed with the closed part of the fork upward. The long sapling is then lashed to the lower ends of the forks, but does not enter the $V$-shaped openings. It does not appear to be as effective an arrangement as the one previonsly described.

Some of the canoes use sails, but most of then depend upon their paddles for motive power. 
During the aku (ocean bonito) fishing season two canoe owners frequently combine forces. In that event the outriggers are renloved from the canoes, which are placed parallel to each other at a distance of about 6 feet, and held in position by two crosspieces running from canoe to canoe at about one-third of the length from each end and firmly lashed. The sail is operated in only one of the canoes. At Kona, Hawaii, is a canoe in the bottom of which is inserted a squale piece of thick glass, so that the fisherman can locate the bottom fishes and hee (octopus) as he slowly paddles along.

Stmpans.-The Japanese use the sampan, a style of boat in general vogue in Japan. It is clumsy and awkward-looking, and a poor sailer, although very seaworthy. Such a boat to be operated by two men is usually about 20 feet in length over all, with abont 6 feet on the keel. The beam is usually about \pm feet 5 inches, while the depth averages 20 inches. The sampans are made of pine. Their most peculiar feature is an overhanging, partly inclosed stern, about 3 feet wide, in which the rudder is worked. The gunwale, from the how for about two-thirds of the length on each side, overhang's nearly 12 inches, and there is a plank about 6 inches in height extending above it. In the bow is a large cubby-hole raised even with the top, in which fishing lines, sails, etc., are stored when not in use. In the center are about 8 compartments $-t$ on a side -12 to 15 inches deep, with plugs which can be pulled out in order to allow the entrance of water, thus making live wells. These small holes-about 6 inches long by 3 inches wide-are crossed with small twigs or wire netting to keep the fish from escaping.

Sculling from the stern is the method invariably used by the Japanese. The oar, which is about 13 feet long, is lashed to a handle about 6 feet in length. This gives the oar a slight angle, which makes sculling much easier than with one solid piece. On the handle is a pin, over which a rope is slipped, holding the scull down to a uniform height while it is being worked. The sweep of the stock at the hand end is nearly 2 feet. The fisherman, planting his left foot on an inclined board, sways his arms and body at right angles to the boat.

The small sampans cost about $\$ 75$ to $\$ 80$, without sails; the largest cost about $\$ 150$. The sails for the smaller ones average about $\$ 7$ per boat, and for the largest ones about $\$ 15$. Quite large sampans, with crews of from 4 to 6 men, are employed in the deep-sea line fishing off Molokai.

Whaleboats. - A few whaleboats are used in the fisheries of certain of the islands, principally by the Chinese. These are of the regulation whaleboat pattern, and have evidently been modeled after boats left behind by the whalers who used to frequent the islands. They average about 25 feet in length, $5 \frac{1}{2}$ feet in width, 26 inches deep, and are sharp at both ends. They cost about $\$ 125$ each.

Rowboats.-These are of all sizes and shapes, from a small, rectangular pine-board boat, worth $\$ 2$ or $\$ 3$, to a handsome, well-built boat costing $\$ 25$. They are used principally in the rivers, fish ponds, and small bays, where the water is smooth.

Scows.-A few scows are employed in the seine fisheries on Oahu, and are of a rough, cheap character which requires no description.

Seineboats.-These are of very much the same pattern as the best rowboats, only larger and more valuable. 


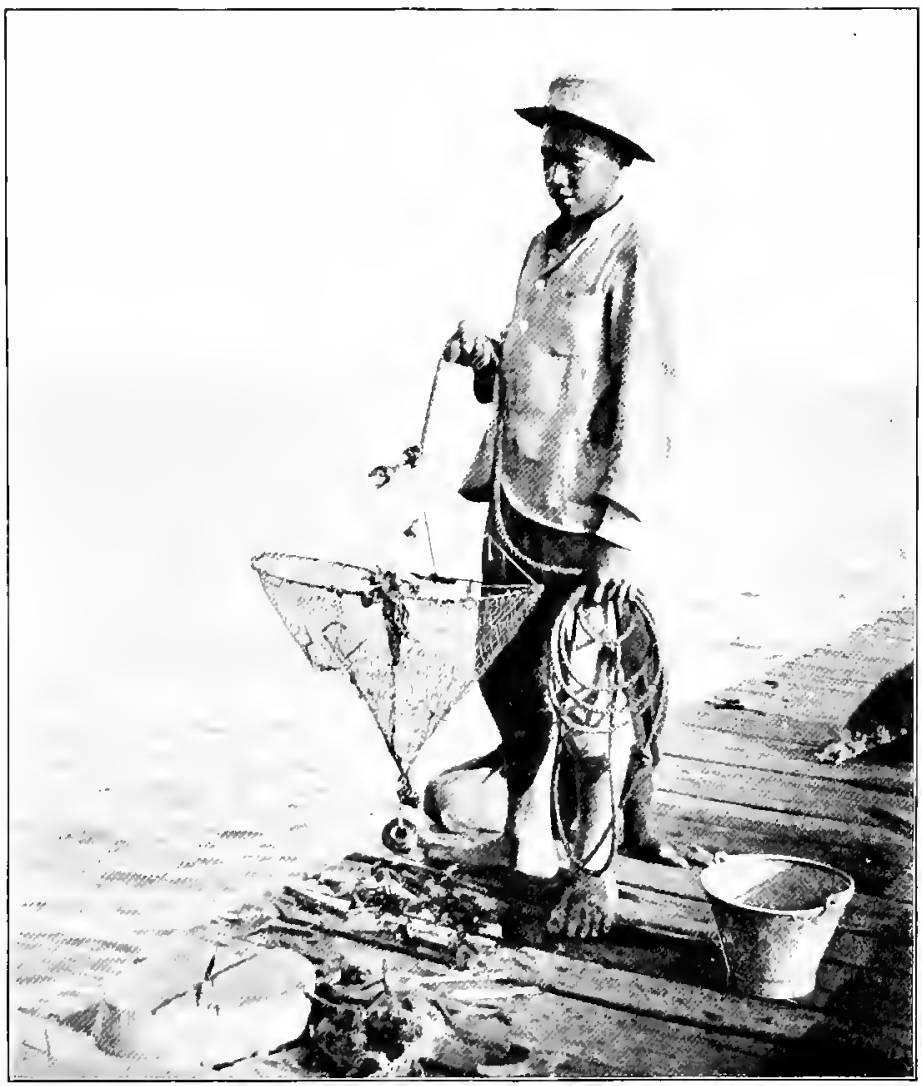

PAPAI (CRAB) DIP NETS.

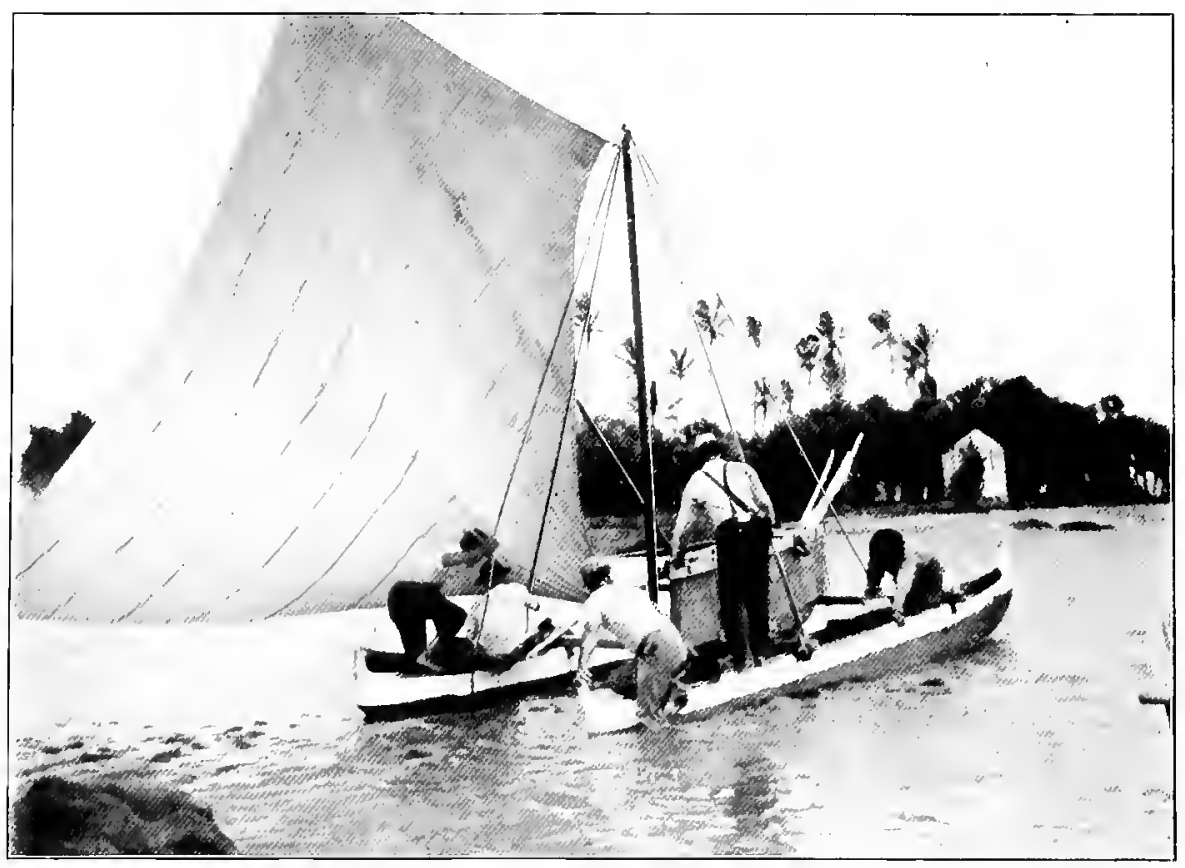

DOUBLE CANOE RETURNING FROM FISHING. 

APPARATUS AND METHODS OF FISHING.

Oving to the proxinity of the sea to all of the habitable portions of the islands, and the natural dependence of the people upon the products obtained from it for a considerable part of their sustenance, the natives early developed into expert fishermen and fisherwomen, and as time weut on gradually evolved newer and more effective forms of apparatus to take the place of or to aid the nore primitive forms. The advent of foreigners hastened this development by the introduction of appliances in use in their own countries and heretofore unknow $n$ in the islands. The earlier American settlers, coming as they did principally from New England, where fishing had been brought to a higher state of perfection than elsewhere in the United States, were especially helpful in this regard.

It has been the endeavor to give as complete a list as possible of the forms of apparatus in use, together with the methods of operating them. Since many forms bear native names, while others have names different from those by which they are commonly known on the mainland, every possible effort was made to see each form and witness the methods of operation. Where this could not be done the statements of reliable fishermen and others were taken.

SEINES.

At Hilo the large seines used on the beach arerage 250 feet in length, with bag 7 feet deep, and mesh of one-half inch. The wings average 4 feet in depth and have a mesh of 1 inch. They are usually made from No. 9 to No. 8 cotton twine.

On Maui seines 150 feet long, 8 to 12 feet deep, with $1 \frac{1}{4}$ inch mesh, are used. They have no bag, and several of them are often laced together and used as one net. They are usually hauled up on the shore.

At Pearl Harbor, Oahu, the Chinese use what is practically a purse seine, 50 fathoms long and 20 fathoms deep, with a mesh of 1 inch in the center and $1 \frac{1}{2}$ inches in the wings. The bottom of the net has rings, with a rope running through them. After the fish are surrounded the lower line is pulled up by the fishermen. The bottom comes up together, thus forming a bag or purse on each side, and this is pulled in until the fish are all in a small bag on each side of the boat, whence they are dipped out by means of small scoop nets.

The bait seines average from 10 to 60 yards in length, with one-half inch mesh or less. They are quite generally used by all classes of line fishermen in securing their bait. No. 3 cotton twine is generally used in the manufacture of these seines.

G1LL NETS.

Gill nets are a popular form of apparatus in the fisheries at the present time. They are either set or hauled; rarely, if ever, drifted. When set they are generally stretched, at high tide, across the shallow openings in the coral reefs. As the tide goes out the fish rush for these openings and become enmeshed in the net. The fishermen are on the seaward side of the net and pass to and fro, removing the fish as fast as caught. This fishing is carried on at night, and the nets are of varying lengths and depths, according to the locality. 
In fishing around clusters of rocks the natives generally surround the rocks with a gill net, which is held to the bottom by means of leads or pebbles attached to the lower line, while the upper line is supported at the surface by pieces of wood

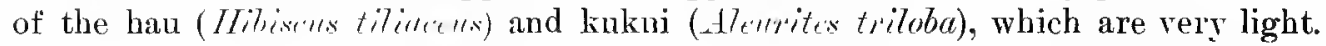
The tishermen dive down to the bottom, inside of the net, and drive the fishes from the crerices of the rocks, to be enmeshed as they dart away in all directions. In this kind of fishing nets about 55 feet in length and 7 feet deep are used, two or more nets being laced together if greater length is desired.

Gill nets are also used at times along the beaches on the leeward side of the islands, where the surf is not beary, the same as seines. Two men take hold of one end of a long net and wade out fiom the shore in a straight line for a considerable distance. The land end of the net is held by a man on the beach. After they hare gone out a sufficient distance, the two men make a big sweep to one side and then pull their end of the net to shore a short distance from the other man. The net is then carefully drawn in, like a haul-seine, until it comes out on the beach, fish and all. These nets are usually 20 fathoms in length, 9 feet deep, with 2 -ineh mesh, and are fitted with leads and corks. Several of them are usually joined together. No hoats are employed in this mode of fishing.

In fishing for ula (crawfish) the same style of net, with a $\%$-inch mesh, is frequently set around a rock or cluster of rocks in the early evening and allowed to remain there all night. As the ula come out to feed during the night they become entangled in the meshes of the net. Another method is to join a number of nets together, putting in the center the net with the smallest mesh. These are then placed on two canoes, which are rowed to the usual fishing ground, which is generally not far from the shore. One man stands npright in order to see the schools of fish more clearly. As soon as a rchool has been sighted the boats are paddled to seaward of it and then in opposite directions, the nets being paid ont as they go. After thus sweeping some distance the boats return to shore, when the net is hauled in and the rarious sections remored, like a seine, until the fine-meshed part is about 50 feet from the beach. The fishermen then sping into the water and draw the two ends together. making a circle, which is further contracted by remoring more sections from the ends of the net, until the fish are inelosed in the fine-meshed portion. At certain fisheries the net is then anchored and the fish allowed to remain in it until they are wanted for shipment, when they are removed by means of a small seine, swept around inside of this improvised pound; and when the fish have been bagged in this they are renored by small dip uets. The principal species taken are the oio (lady fish, kala (hog-fish), nenue (rudder-fish), and large awa-kalamoho (milk-tish).

In a variation of this method the boats carry the nets in a circle, one boat passing within the course of the other when they meet, and continuing until there is a coil of netting around the tish. The purpose of this is to insure the capture of the fish in outer lings of the coil if they excape the inner ones, and when the trap bas been thus set the fishermen jump into the inner circle, and, hy beating the water with their canoe poles, frighten the tish into the nets, where they are enmeshed.

Sometimes the net is dropped in a half circle. with a man at earh end to hold it thus. Other tishermen then make a wide sweep to the opposite side of the opening, from whence they advance, beating the water violently with their arms to drive the 
fish toward the net. When the beaters have approached sufficiently near, the men bolding the ends of the net advance toward cueh other, and when they meet, with the help of all the fishermen, the circle is gradually reduced as the net is hauled in and section after section removed. The fish which have become enmeshed are taken out of each section as it comes in, and when the inner cirele is snall enough the fishermen renore with dip nets those which are not enmeshed. This method is practiced by either day or night.

In fishing for akule nnusually long nets are frequently enployed, some used at Hilo being 20 fathoms long, \pm fathoms deep, with mesh of four inches. These are made of No. 12 linen twine and are worth ahout $\$ 100$ each. Most of the net.s, however, are of abont one-half the above dimensions and are worth about $\$ 50$ each.

On Hawaii a man is posted on a high bank to watch the morements of the sehool of akule (goggler), which, owing to the color of the fish, looks like a red bank, and is more plainly visible from this elevated position than from the eanoes. This lookont is provided with a Hag in each hand, with which he directs the movemeats of the fishermen in handling the net.

Nearly all the seine and gill nets are barked before being used, to prevent rotting. For this purpose the bark of the koa tree is used, being pounded up somewhat fine and put in a tank of water to remain for two weeks, after which the water is drawn off and the nets slowly run through it.

In drying the nets a method introdueed from China is employed at several places, particularly Hilo. Throughont an open field are planted a number of slender poles about 12 feet in height, and at the top of each is nailed a crosspiece of wood about 3 feet in length, which is supported by two short pieces running from the pole to the onter ends of the erosspiece. Large hooks are attiched to the ends of the crosspieces. A short piece of lope is slung orer "ach of the hooks, and when the net is ready for drying it i, attached to one end of this rope, pulled up sufficiently to clear the ground, and held in this position by tying the free end of the rope to the pole close to the ground. This procedure also facilitates the repairing of nets.

BAG NWTS.

Bag nets are used on all of the islinds, and are the most common form of apparatus. They are of all sizes and styles, areording to the particular species the fishermen are seeking and the condition of the fishing ground.

Several of the more important fisheries are conclucted with bag nets. At Kahului, Maui, there is in use a net 180 fathoms long, with ropes 250 fathoms long on each side. It is made of cotton twine, and the wings bave a mesh of $t$ inches, the eenter. 1 inch. The net is operated from the shore by means of two windlases. When drawn near the shore a bag 15 feet wide, 17 feet higl, and 35 feet long, with meshes 1 to $1 \frac{1}{4}$ inebes, is attached to the center of the net, and the latter unlaced at this point and the ends drawn back to the sides of the bag, this work being done by divers. If there is only a small haul the bag is drawn direetly up on the beach. If many fish have been taken, the bag is placed in a eanoe, the rope at the bottom of the bag unlaced, and the fish allowed to fall into the boat.

The bag net in general use is about 21 ) feet in depth in the bag, 12 feet wide at the mouth, and runs to a point. Wings about 30 feet in length and about 5 feet 
deep, with meshes of three-fourths to 1 inch, are attached to each side of the mouth of the bag. Floats made from wood of the hau tree, which is very light, are strung along the upper line of the wings and the bag, and leads are attached to the bottom line. The end of the bag is generally open when on shore, but is tied with a piece of twine before being put overboard; the fish are removed from the bag at this end. The nets are made of manila hemp, which costs $\$ 1.25$ per pound, and 9 pounds are required to make a net of the above dimensions. Cotton twine also is used at times. Sections of rope from 15 to 20 fathoms in length, fastened together with hook and loop, and having the dried leaves of the ki plant braided on them by the stems, the blade ends of the leaves hanging loose and free, are taken out along with the net. The sections of rope are joined together, and men taking hold of each end and moving in opposite directions begin to make a sweeping circle. Others follow to keep the rope near the bottom, and when it catches on rocks or coral dive down and release it. When the men holding the ends of the line meet, one steps orer the line of the other. and so they keep on going round and round, gradually narrowing the circle until it has become sufficiently small. In the meantime the varions sections of rope not needed are unhooked piece by piece and allowed to float on the surface. The bag net is then taken out of the canoe and attached to the ends of two of the sections. The men continue narrowing the circle until the fish are all driven into the bag, which is then closed up, lifted into a canoe brought up for the purpose, the string holding the point of the bag untied, and the fish allowed to drop into the bottom of the boat.

A variation of the above net, but on a larger scale, has been invented by Mr. E. H. Bailey, of Kahulni, Maui. A smooth spot of bottom, inside of the reef, in a fairly shallow place, is selected for placing the net, which is the same as described above, except that it has a net platform in front, attached to the mouth of the bag and also to the wings. Two lines of ki leares are put together so as to make them thicker and thus more effective. Buoys are attached to the rope by means of short lines, and the ropes sunk by leads until the tips of the leares just scrape the reef. The ropes are run out in a half circle and then pulled over the reef, after which the ends are swung around until they encircle the bag. The ropes are then carried round and round until all of the fish are over the platform, when the latter is raised up and the fish forced back into the bag. As soon as the platform reaches the surface the ropes are withdrawn. The canoes then form a triangle and the mouth of the bag is drawn up between them and the fish taken out with dip nets.

Opelu nets (upena aai-opelu) are arranged on two half-hoops connected at each end; the hoops lap over each other and are tied together so as to keep the bag open when in the water. A rope runs from each of these and meets a short distance above the bag, from which junction there is only one rope. The bag itself is very deep, usually about 40 feet, with a diameter of about 12 feet at the month and tapering slightly at the bottom, and is made of imported flax, so as to be as light as possible. When operated the bag is taken out in a canoe and lowered into about 8 fathous of water. Bait, composed of cooked squash or pumpkin, small ground-up fish mixed with sand, and cooked papaia and bananas mashed up fine, is dropped into or over the bag. When the fish are gathered over and in the bag it is carefully and rapidly drawn up, and when it reaches the surface the ropes on the side are unloosed and the 
mouth closed up. It is then emptied into the canoe and the operation repeated until the fish become shy. The opclu, when eaten raw, is said to prevent seasickness.

The natives sometimes construct the above net from twine made from the bark of the olona (Touchardia latifolia) bush or shuub, which grows in large shoots. These are cut down and the bark stripped off in bundles and put into lunning water, to prevent fermentation and in order that the pulpy matter, etc., may decompose. After four or five days, or when it becomes thoroughly clean, the bark is taken out and spread on hard-wood boards 6 feet long and 8 or 10 inches wide. The wood used for these boards - kauwila -is very scarce and valuable now. When the bark has been thus spread the inside of it is carefully scraped by means of a bone $2 \frac{1}{2}$ inches wide and 10 inches long, with one side beveled to an edge, and the perfectly clean fiber is dried. It is then stripped into fine threads and twisted together by women, who roll the strands on their bare thighs with their hands, making a cord that is stronger than linen and will last for generations.

For catching nehu (anchovies and silversides), very small fish much used for bait and for food when dried, a bag net (upena nehu) is made from a piece of netting about a fathom square, attached on two sides to sticks about 3 feet in length and fulled in at the bottom on a rope shorter than the upper one and forming an irregular square opening to a shallow bag, which is supplemented by a long, narrow bag about 6 feet deep. Ropes hung with dried ki leaves are attached to each side of the net, and these ropes are run around the school to drive the fish into the net. Nehu fishing is generally carried on in deep water.

A bag net (upena pua), made in the same manner, is used for catching very young ama-ama (mullet). Instead of ropes with ki leaves, the "sea Convolvulus, generally found growing on the beach, is twisted-leaves, branchlets, and all-into two thick bushy ropes some 15 to 20 feet in length, and these are attached on each side of the net to the kuku (side sticks). These lines are then drawn forward in a semicircle, sweeping the shoals of fry before them till enough are partly inclosed, when the two free ends are rapidly diawn together in a circle, which is gradually reduced till the fry are all driven into the bag."

A bag net very similar to the above is used in fishing for ohua, a small fish very highly prized by the natives, which lives in and on the limu kala, a coarse alga that grows on coral in shallow water. Long ropes with dried ki leaves are employed, and the method of operation is the same as already described.

A bag net called kapuni nehu is also used in catching nehu. This bag is about 6 feet deep and 3 feet wide at the mouth, and two parallel sticks are used to keep the month open. When a school of nehu is seen working its way along close inshore, two men go out with the net, each holding one of the sticks. Others get in the rear of aind on the sides of the school and frighten the fish into the bag, after which the sticks ale brought together, thus closing the bag, which is then hauled ashore or put into a canoe and emptied. These bags are of very fine mesh and are made of a certain kind of Chinese netting, which is said to be exceedingly strong.

A bag net called upena uhu is employed in catching the uhu, some highly prized labroid fishes, chiefly species of Calotomus. This is made of a square piece of netting. which has been gathered slightly on the ropes and attached at the four corners to slender, strong sticks tied together at the middle in such way that they will cross 
each other at this spot and can be brought together when wanted. A string is tied at the crossing place of the sticks and the net is manipulated by this string. When these sticks are crossed they spread the net open in the form of a shallow bag. The fisherman tirst catches an uhu of the viriety to he fished for by means of hook and line. He secures this to a line r'un through its gills and mouth and then lowers it at a spot where the nhu congregate and gently works it back and forth. The uhu in the ricinity are attracted and angered l,y the strange antics of the decoy and swin up close to observe it. The net is gently lowered to a little distance from the decoy, and the lattel is then slowly drawu into the net. The others rush into the net after the decoy, when, by a peculiar twitrh and pull on the string, the fisherman causes the sticks to swing around and lie parallel, closing the mouth of the bag, which is then drawn to the surface and emptied into the canoe. The operation is then repeated with a fresh decoy.

'There are two varieties of uhu, one of a reddish color and the other green. The red rariety is preferled hy the nativer, who eat it raw. This same net is used for other species of rock-fish, the decoy being of the species soingt.

A similar bag net (upena opule), ahout a fathom in length and with an oval mouth about 2 or 3 feet in width, is nsed for catching the opule, a decoy opule being used in the same manner as described above.

Another kind of decoy fishing is with the lau melomelo, a billet of kauwila wood, one of the hardest varieties in the islands. This decoy is something like a club, being rounded at the ends, with one end smaller than the other, and a little ringed knob on the smaller end to tie a string to. It varies in length from 13 inches to 3 feet. After the proper incantations have been performed over it by a sorecrer, or kahuna, it is charred slightly orer a regulation fire. Having once attained its power great care must be taken by the tisherman that it does not lose it. If a woman should step orer it or enter the canoe in which it is placed the magic influence would be lost. Further preparation is made by baking equal quantities of kukui nut (candle nut) and cocoa- . nut meat, pounding it up and tying it in a wrapping of cocoanut fiber (the sheath around the items of the cocounut leaf). On arrival at the fishing-ground the stick is covered with the oily juice of this preparation and allowed to hang suspended a few feet from the bottom. The scent of the baked nut meat, in the opinion of the fisbermen, has an attraction for certain kinds of fish, which soon surround the stick and smell or nibble at it. In a short time a small bag net is dropped overboard, and maneuvered until its mouth is toward the suspended stick. The latter is then moved slowly into the bag, the tish following it. Two of the natives dive and, approaching the net gently, quickly close its mouth and give the signal to those in the canoe to haul it up. Should the fishing prove poor it is ascribed to the imperfect performance of the incantations. This manner of fishing was formerly quite common on the west coast of Hawaii, but is not often practiced now.

One of the common species around the island of Oahu is the malolo, or flyingfish, although but few of these are found around the other islands. There are two species, the large malolo and the suall puhiki'i. A large bag net with a flaring mouth and very fine mesh is employed in this fishery, being carried to the fishing ground piled on a large single canoe, or sometimes a double one. The start is always 
made early in the morning, and a number of 'anoes usnally go out together, many of the occupants being women, as no particular skill is required in the part of the general bands. The work is directed by the kilo, or sps, who is g'rrerally in a light canoe manned by two or three hands. He stands up on the cross-ties of his canoe, and shading his eyes with his hand, watches for signs of the school. As soon th he discerus a strong ripple, which appears to indicate the presence of the school, he signals to the rest of the canoes, which at once surround it. The kilo points out the best place for dropping the net, and as soon an it is in place the canoes approach quickly, the men splashing the water with their hands and poles, and driving the school hefore them into the open bag. The malolo will not dive to any depth, and are always found swimming very near the surtace, so that, when completely surrounded by the canoes, they can be driven wherever wanted. This fishing is called lawaia-o-kaiuli, "blue-sea fishing," by the natives, as they frequently have to go several miles out to sea after the fish. A favorite spot is off Waikiki beach on Oahu. The malolo is frequently pounded up tine by the natives and eaten raw, mixed with other substances.

The iheihe (a species of halfbeak, Euleytwhomphus), a long, thin fish, nsually a foot and a half in length, with a very sharp-pointed snout, generally arrives at the islands about the same time as the malolo and the akule, and is sometimes captured in a similar net and in the manner already described.

The largest bag net in use is the upena kolo, and owing to its size it can be used at only a few places around the islands, Honolulu harbor being the principal one. The bag is fine meshed, so that small fishes can not exc:ly, and is 16 to 24 fathoms in depth, very narrow at the extreme end, but widening into an immense flaring moutl. Attached to the mouth on each side are wings 16 to 21 fathoms deep. This net is swept around the harbor by natives in eanoes, who pull the net with lopes, scooping up everything in its path, the principal species taken heing the hahalalu, the young of the akule, and the amaama, or mullet.

Upena poo is a small bag net, with a light supple pole cut from the pohnehue

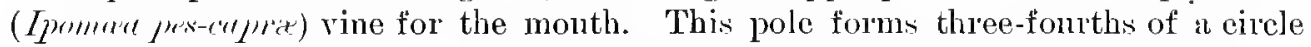
when not in use. When in operation the fisherman draws the two ends together, crosses them, and holds them tight in his hand. A small stick, with pieces of rag or lau hala leaves attached to the end, is also a part of his equipment. The canoe is paddled immediately orer a rocky bottom where holes are numerous, then the fisherman takes the bag in his left hand and the small stick in his right, and dives. He pushes the bag elose up to one of the holes and with the stick brushes the fish into it. He then allows the two ends of the pole to slide down in his hand until they lie parallel, and this nearly closes the mouth of the hag, after which be ascends to the surface and empties the bag into his boat.

Another style of net is arranged upon two sticks parallel to each other, about 6 inches apart, the bag being about $2 \frac{1}{2}$ feet in depth and width. One stick is supple, while the other is rigid. The fisherman pushes the pliable stick along the other until its end is about the middle of the latter, and holds it thus bowed out and making an opening for the fish. When he wants to close it he merely lets the stiek slide back until it is even with the other, when he holds both tight. 
Mr. J. S. Emerson, of Honolulu, furnishes the following account of a fishing expedition he made with a native, when he used a bag net somewhat similar to the two just described:

We started at sunrise from the shore in a little canoe capable of holding two persons. The native had only a malo (breech clont) for his dress. He had with him some of the candle nut (kukui). This he chewed np in his mouth and spat the chewed material on the surface of the water. This produced a film so that he could look down from the now calm surface of the water to a depth of 6 fathoms or more and locate the little caves and holes in the coral where the fish were. When he had discovered the proper location of these fish holes, he laid his paddle down in the boat and took a hand net in one hand. The bag of this hanıl net was like a purse. There were two sticks to hold it open and these were upon two sides of a triangle; the mouth of the net was tied to the sticks. In the other hand he had a fish brush-a rude fly brush about 3 feet long-composed of a stick to which were tied bits of bark, etc., to make a hrush to drive the fish. He sprang into the water-in one hand the net and in the other the fish hrush. I noticed sometimes he had it in one hand and sometimes in the other, it apparently did not matter which. He dove down, propelling and guiding himself entirely with his feet, with his eyes wide open, and approached the spot at the bottom, 6 or 8 fathoms deep, with the brush in one hand and the net in the other, ready for work. Then with the one hand he stirred up the fish from their resting places and drove them into the net as one would drive little chickens. Having secured all the fish from that particular spot he closed his net, held the net and brush in the same hand and userl the other hand to paw his way to the surface. On arriving there he blew the water out of his mouth and nose, threw his head back and got into the canoe. He remained helow the surface about two minutes. There were in the net 3 or 5 fishes about 6 or 7 inches in length. He then cheweit up some more of the nut and proceeded for a few rods ahead, spat out the nut on the water, looked down, and went through the same operations again, finding a few more fish there. This he did for several times, say, possibly, at a dozen places.

Certain methods of bag-net fishing which were in vogue years ago have been entirely abandoned, or at most are but rarely used. Among these is lau kapalili, which was called the "fishing of kings," as they only could command a sufficient number of canoes, men, and lau. The late Kamehameha $V$, whose farorite residence was at Waikiki, frequently ordered it. The following is a description of this fisher: :

Lau kapalili is the use of a large bag net, smaller than the kolo but larger than the ohua or iiao net, but of the same general shape, and callerl a papa. Two rope laus of 300 or 400 fathoms in length, with ki leaves attached, the same as in lau ohna, and generally the lau of two or more ohua nets joined, are piled onto a large double canoe, which is taken out 2 or 3 miles from shore, attended by a fleet of from 60 to 100 single canoes. The head fisherman always goes on the canoe containing the net and lau. Arrived at the proper distance, which nust be just opposite the final drawing place, the end of one rope is joined to that of the other, and two canoes, nnanned by 8 or 10 strong men, take the other end of the rope or lau, one each, and start in opposite directions and exactly parallel with the shore, while the double canoe remains stationary till all the lau is paid out. In the meantime the rest of the canoes have divided into two companies and follow the learling canoes, stationing themselves at certain distances on the lau and helping to pull it.

When the lau is all paid out the two leading canoes then curve in to form a semicircle, at the same time always moving toward the shore. When a perfect semicircle has been made by the lau the double canoes and all the others move gradually forward with it, while the leading canoes are pulling with all their might straight in to the shore. When either end is landed the men immediately leap out, and taking hold of the line pull on it, at the same time going toward each other, which has the effect of narrowing the semicircle, while most of the canoes keep hacking on to the double canoe, which always keeps the center. Arrived at a suitable place, always a clean, sandy one a few rods from shore, the laus are untied and attached to each end of the papa net. Men, women, and children

a Hawaian Fisheries and Methods of Fishing, with an Account of the Fishing Implements used by the Natives of the Hawailan 1slands. By Mrs. Eman Metcalf Beckley. Pp. 18, 19. 
now gather closely on the lau, especially where it joins the net, and make a great disturbance with their feet, which drives all the fish into the net. Lau and net are finally drawn ashore.

Lau kapalili (trembling leaves) fishing can only be carried on on a clear, bright, sunny day, so that the shadows cast by the leaves can be seen and serve to drive the fish inland.

\section{DIP AND SCOOP NETS.}

It is frequently difficult to distinguisb between a dip net and a bag net, as certain forms of each are very similir in construction and methods of operation. In some cases an arbitary line has been drawn.

In fishing for maikoiko (surgeon-fish), a dip net about 6 feet deep and 4 feet in diameter is used. A bag of bait tied to the end of a stick is pushed into the water near the holes in which the fish live, and when they are lured out by the scent of the bait the dip net is carefully slipped under both bait and fishes and then raised slowly until it reaches the surface, when it is lifted or drawn ashore.

Another method is to chew up bread fruit and taro and spit these upon the surface of the water. As this slowly sinks below the surface the fish are attracted in large numbers and fall easy victims when the dip net is slipped below them and then quickly raised to the surface.

A common form of dip or scoop net, which is generally used in removing fish from seines and bag nets, is made by bending a flexible piece of wood into an oval shape and tying the ends together at the junction. To this is attached the net, which has a bag about 2 feet deep, much narrower at the bottom than at the top. When not in use the lower end of the bag is left open, but when used it is gathered together and tied with a piece of twine.

On Kauai a dip net with a bag about 2 feet deep, attached to an iron ring 2 feet in diameter, is used in catching papai (crabs). This net is attached to a long pole by means of four ropes running from the ring to a conmon center about 2 feet above the ring, and thence by a single rope. The bait is either tied to a rope attached to and hanging down a short distance below the junction of the four ropes, or else weighted down in the bottom of the net. April, May, and June are the principal months for this style of fishing. It is usually done at night. Somewhat similar dip nets are occasionally employed in fishing for ula (crawfish).

On the Waiawa River, near Pearl City, Oahu, the Chinese use a form of dip net which was probably introduced by themselves, as it does not appear elsewhere on the islands. The river is narrow, about 40 feet in width. Four poles are planted, two on the edge of the bank, and the other two about two-thirds of the distance across the river, thus forming a square. All of these poles are slanted outward, so much so that the tips of the outer ones extend almost to the opposite bank, and a large, square, fine-neshed net is attached to them by ropes. On the shore is a windlass connected with the net by a rope, and used in raising and lowering it. Bait is thrown into the net, which is then lowered into the water until it almost touches the bottom, where it is allowed to remain until a number of fish have congregated over it eating the bait. It then is raised above the surface and the fish removed.

A scoop net is made by tying a square fine-meshed net to two slender sticks, laid parallel to each other and about 5 feet apart. One side of the net is then gathered together until the ends of the sticks on that side are within about a foot of 
ach other, when it in secured in this position. A rude sort of bag is thus formed at the gathered end. In operating the net the two ends of the sticks at the bag end are beld in one hand and the flaring end is pushed around stones, etc., in slallow water, thus scooping up the tish, papai, and opae. By lifting the flaring end out of the water the catch falls back into the bag, from whence it is easily lemoved with the hand. This net is yuite generally used around the leeward side of Oahu.

CAST NETS.

The cast net (upena poepoe) is a comparatively recent introduction in the islands, having been brought in by the Japanese about ten years ago, so it is reported, althongl this is somewhat doubtful. The nets, which are circular, average about 25 feet in circumference and have $1 \frac{1}{2}$-inch mesh. They have leads all around the sides and are made generally of No. 10 cotton twine. They are worked from the shore. Unlike the fishermen in the United States, the Japanese hold no part of the net in the mouth, but manipulate it entirely with the bands. About two-thirds of the outer edge is gathered up and the net is thrown with a sort of twirling motion, which caines it to open wide before it touches the water. The leads draw the outer edges down very rapidly, and as they come together at the bottom the fish are inclosed in a sort of bag. The net is then hauled in br means of a rope attached to its center. the weight of the leads causing them to hang close together, thus preventing the fish from falling out as the net is hauled in. The fish are shaken out of the net by merely lifting the lead line on one side.

BASKETS.

With the exception of those for catching opae (shrimp), the Hawaiians use few baskets (hinai), this forn of apparatur belonging principally to the South Sea Islanders.

In opae fishing two varieties of baskets are used. One, the hinai opae, sometimes called apua opae, looks somewhat like the coal-scuttle bonnets in rogue some yeas ago. It is woven fron the air roots of the ieie (Freycinetic arboren). This basket is employed for catching shrimp in the mountain streams, and the work is generally done by women, who hold the basket in one hand, a short stick in the other, and, moving in a crouching position through the water, drive the opae from under the rocks, etc., to some place where the grass, ferns, or branches of trees droop orer on the water. The opae take refuge in or under this regetation, and the fisherwoman, placing her basket under the leaves, lifts the latter out of the water, when the opa drop off int, the basket, from whence they are removed to a smallmouth gourd, which the woman has been dragging behind her in the water by a string tied to her waist.

Another method of fishing in the streams is to take a fairly deep basket with a large month, and, putting this in a farorahle spot in the water, build a mud wall on both sides of it extending out a short distance. The fislierwoman then goes a little way upstream, and by beating the water drives the opae into the basket, which she removes and empties, then going on to another place and repeating the operation. 


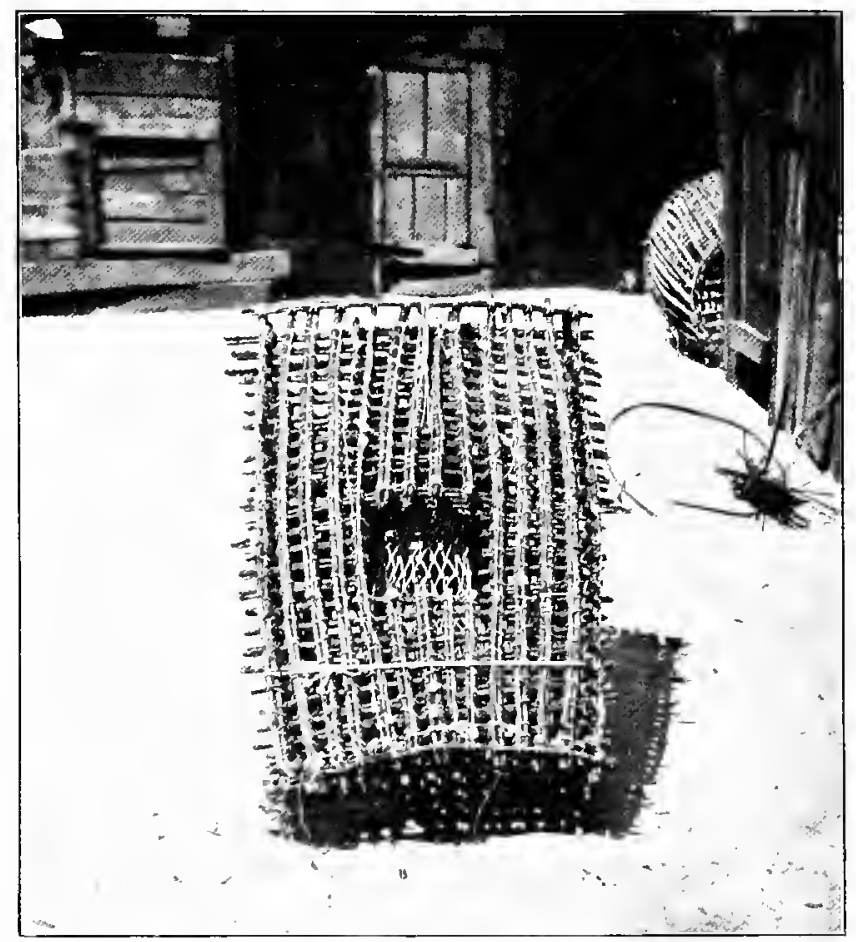

PUHI (EEL) BASKET TRAP.

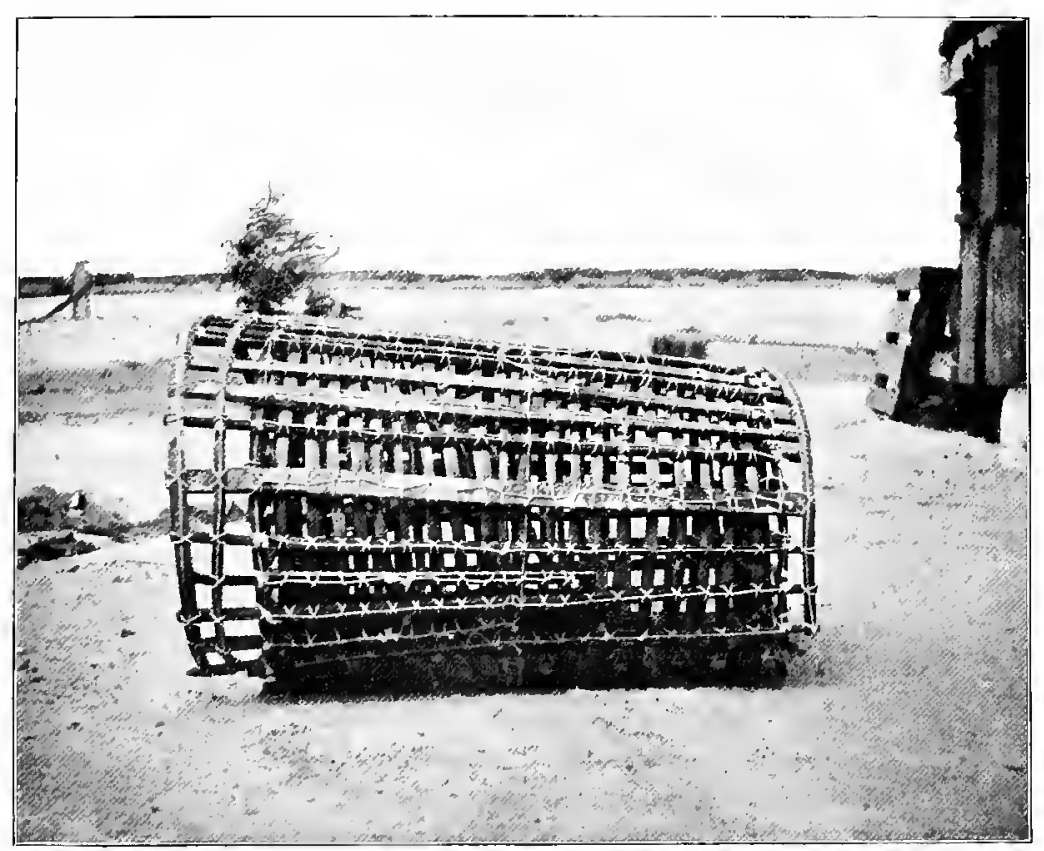



The basket used in fishing for opate in salt and brackish water has a wide flaring mouth, gradnally sloping toward the center, a few inches from which it suddenly branches off into what looks like a long circular spout inclosed at the cxtreme end. The size of the baskets varies. Holding the basket in the left hand the women wade out in an almost nude condition to a suitable spot, where they sink down until only the head is virible, and pushing the right hand under the rocks, drivo the opae into the basket, which is so manipulated as partly to euvelop one side of the stone. The mouth of the basket is closed by drawing the sides together and bolding them in this position. The opae are then transferred to a gourd floating alongside, which the fisherwoman keeps attached to her by a rope tied around her neck. The women are expert in this method of fishing and rarely fail to make good catches.

The hinai hooluuluu is used in hinalea fishing, and is a small basket made from the rines of the awikiwiki, a Comploulus. After a light framework of twigs has been tied together, the rines; twigs and all, are wound in and out, round and round, until of the requisite size, 3 or 4 feet in circumference and about $1 \frac{1}{2}$ feet deep. Pounded opae inclosed in cocoanut fiber is occasionally placed at the bottom of the basket for bait, but usually the scent of the bruised and withering leaves seems to be sufficient. Women always attend to this kind of fishing. They wade out generally to small sandy openings in coral

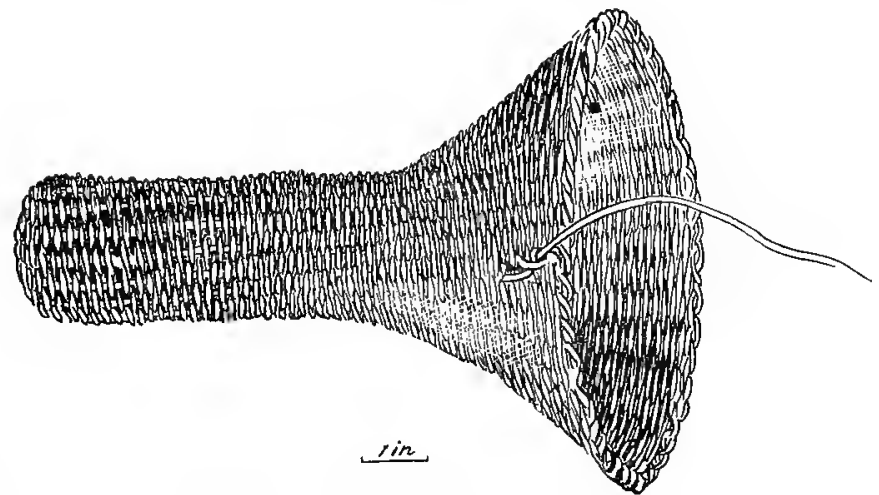

Fig. 231.-Basket for catching opae (shrimp), ground or reef, and let down the baskets, properly weighter to keep them in position, the weights attached in such a way as to be easily remored.

Each woman moves some distance away from her basket, but to a point from whieh she can watch the fish enter it. When all the fish that are in sight have entered, the basket is tak'n up, the firh transferred to a large small-monthed gourd, and fishing resumed in another place. This method can be lised only on a calm sunny day and at low tide.

Baskets made from the awikiwiki must be renewed from day to day. Some are made from the ieie vine, while still others have been made from the weeping willow since its introduction some year's ago. These latter can be nsed over and orer again.

Sometimes these baskets are placed in fairly deep water, where stones are piled around them to keep them in position. For bait the wana (sea egg), with the shell broken to expose the meat, is put in it. The basket is left for a day or two before being taken up.

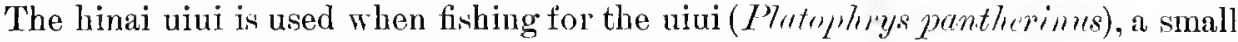
flat-fish, said to make its appearance at intervals of from ten, fifteen, to twenty 
years. Its appearance is taken by lishermen and the people in general as a sure precursor of the death of a very high chiet. The basket is shallow, of about the same size as the hinai hooluuluu, but wider mouthed. The following is a description of the methods of fishing followed on the last appearance of this fish: ${ }^{a}$

At the last appearance of the uiui the imported marketing baskets were generally used by those who could not obtain the old-fashioned kind, as any old cast-away basket would do, with a little patching, occurying perhaps five minutes, and two sticks lent over the mouth or opening from side to side, and at right angles to each other, for a handle to which to tie the draw-string. It should be twisted round and round above the jointure with a little of the sea convolvulus (pohuehne) with the leaves on, so as to throw a little shade in the basket to keep the fish from being drawn up to the surface of the water. In these baskets cooked pumpkins, half-roasted sweet potatoes, or raw ripe papayas were placed for bait. The canoes, thus provided, would sail right into the uidst of a school of these fish; the basket being lowered a few feet into the sea, the fish being attracted by the scent of the bait would rush into the baskets and feed greedily. As soon as the baskets were full of fish they would be drawn up and emptied into the canoe and then lowered again, with more hait if necessary, and this would go on till the canoe was loaled or the fisherman was tired. These fish are very good eating when they first arrive, as they are fat, with liver very much enlarged; after a month they become thinner, not perhaps procuring their proper fnod here, and then taste strong and rank. natives:

The following, from the same source, describes a basket occasionally used by the

The ie kala basket is the largest kind of basket used in fishing by the Hawaiians. These are round, rather flat, baskets, 4 to 5 feet in diameter by $2 \frac{1}{2}$ to 3 in depth, and about $1 \frac{1}{2}$ across the mouth. A small cylinder or cone of wicker is attached by the large end to the mouth and turned inward toward the Dottom of the basket. This cone or eylinder is quite small at the free end, just large enough for the kala to get in. Immediately below the end of this cone, on the bottom of this basket, is placed the bait, properly secured, which in the case of the kala is limu kal a (a coarse, brownisb-yellow alga on which this fish feeds and from which it takes its name), ripe breadfruit, cooked pumpkins, and half-roasted sweet potatoes, and papayas. This basket is called the ie lawe (taking-basket). The fishermen generally feerl the fish at a given place for a week or more before taking any, using for this purpose a large basket of the same kind, without the inverted cylinder, and wider in the mouth, to allow the fish free ingress and egress. After a week or two of feeding they become very fat and fine flavored, as also very tame, and baskets full of fish can be drawn up in the taking basket without in the least disturbing those which are still greedily feeding in the feeding baskets. These baskets are oceasionally used for other kinds of fish, substituting the bait known to attract that particular kind, but never with the same degree of success as with kala.

The South Sea Islanders living at Honolulu and Lahaina have introduced two new types of baskets. The larger has a flat bottom, and is otherwise the shape of a half cylinder, the top gradually sloping to the rear end. These baskets are about 3 feet long, 2 feet high in front, and $1 \frac{1}{2}$ feet in height in the rear. The outer framework projects about 2 inches beyond the front and back. The baskets are made of flexible twigs lashed together with twine. A cone or funnel, 6 to 8 inches in diameter and about 12 inches long, with the end cut off, is inserted at the larger end, the body of the cone being inside of and opening into the basket. At the end of the cone a trap-door of wickerwork, about 4 inches square, is fixed in such a manner that it will open at a touch from the outside, but can not be pushed open from the inside. The basket is weighted down with stones or two pieces of old iron run lengthwise of the basket on the bottom and lashed there. In the rear of the basket is a small trap-door

a Hawailan Fisheries and Methods of Fishing, with au Account of the Fishing Implements used by the Natives of the Hawailan 1slands. By Mrs. Emma Metcalf Beckley. 
for removing the fish. When used the basket is taken to a sandy place in 2 to 4 fathoms of water, where there is plenty of coral or stones. The fisherman dives and places it in a good spot, then takes pieces of coral rock and builds them up and around the basket until it is completely inclosed, so as to form an artificial dark retreat for the fish. The opening to the funnel is left exposed, however, and the fish, seeing the inviting entrance, go into the trap. The basket is left for from two days to a week, when the stones are displaced, the basket hauled up into the canoe and emptied by means of the back door, and then replaced in its former position.

Hinai puhi is the other form of basket used by the South Sea Islanders. It is oblong, about 25 inches wide, 18 inches high in front, and 3 feet long. The top gradually slopes to the rear, where it is only about 12 inches high. A funnel, or cone, about 8 inches in diameter and 10 inches in depth, extends into the basket in an upward direction, and has an opening on its underside which leads down into a square space about one-half the width of the basket. This space, which begins about halfway of the length of the funnel, runs abont 5 inches farther into the basket. From this space another funnel, with a narrow slit opening, leads into the body of the basket, the mouth held taut by lines run from it to the sides. Both funnels are constructed of netting, while the rest of the basket is made from the branches of the guava tree. Bamboo, owing to its lightness, is sometimes used for the top. The branches are lashed together with stout twine, no nails being employed. It takes abont a week to make one of these baskets, but they will last a long time. They are used for the capture of the puhi, or moray, which is quite common around the islands.

\section{FISII TRAPS OR PENS.}

On Pearl Harbor, Oahu, two fish traps are used for catching sharks and large akule (goggler), opeln (mackerel sead), weke (goat-fish), and kawakawa (bonito). The larger, near Puuloa, has two walls which, for a short distance, run out from the shore in parallel lines. Then one of them sweeps out and around, forming a large and almost oral space. A wall is built parallel to the shore and the outer portions of the oval meets it close to one end. The other line from the shore comes out almost to this parallel line and then turns sharply inward for a few feet, and the space between the two, about 4 feet, forms the entrance into the trap. The walls are built of coral. The end of the oval farthest from the entrance is almost bare at low water, while the sicle next to the gate has about 5 feet of water. At high tide the whole trap is under water. Fish enter it at high water and are canght as the water recedes. They are taken out at low water by means of a small seine.

\section{SPEARING.}

The natives are very expert in fishing with the spear, and use it with equal facility either below or above the surface of the water. The spear is nsually a slender pole 6 to 7 feet in length, made of very hard wood, and tipped with a thin piece of iron $1 \frac{1}{2}$ to 2 feet in length. Most of the tips are perfectly smooth, hut a few have a very slight barb. The spearing of fish is called "ia o" by the natives.

The spearing of the species inhabiting the rocks in shallow water is carried on under water. Diving to a favorable spot among the rocks, the fisherman braces himself in a balf-crouching position and waits for the fish to come. He notices only 
fish passing before and parallel to him and those coming straight toward him. For the former he aims a little in advance of the fish, since by the time it is struck its motion has carried it so far forward that it will receive the blow on the gills or middle of the body and thus he secured, whereas if the spear were aimed at the body it would be apt to hit the tail or entirely miss the fish. 'The spear is generally sent with such force that it goes entirely turough the fish, thus bringing the latter up to the upper part of the spear, where it remains while the fisherman strikes rapidly at other fish in succession, should they come in single file, as they usually do.

The above-water spearing is generally for Maki maki (the swell-fish, Tetraodon. hispidus), which is said to be poisonous; for hee (octopus); and for honu (turtle). The oopuhue is either speared from the walls of the fish ponds or in the open sea.

In the deep-sea line-fishing spears with short poles are frequently employed in killing certain species brought to the surface on the lines.

In fishing for puhi (eels) the latter are attracted out of their holes with bait and are then speared.

Spears are frequently used in fishing for the hee (octopus), principally hy women. 'This animal generally makes its home in small circular holes in the rocks on the reets. When the fisherwoman finds a hole that she thinks is oceupied she runs the spear into it gently. Should a hee be there it comes out to see what is the matter, the spear is run through it, and it is brought to the surface. The woman usually carries a smaller spear also, and with this she pricks or hits the animal in the head until it is stunned or killed, otherwise it might twine around her arms or legs and cause serions difficulty.

Honu (turtle) are generally captured by means of spearing from the rocks along the shore where they congregate.

\section{DYNAMITING.}

Probaloly one of the most destructive methods of fishing is with dynamite, or giant powder, as it is generally called in the islands. This explosive was first used for this purpose in 1860 . A stick of dynamite weighing about a quarter of a pound is capped and arranged with a fuse abont 10 inches long. The fisherman usually selects a deep hole, and paddling to within a short distance of it, lights the fuse and when it has hurned almost to the cap throws it from him into the hole. When it explodes every living thing within a considerable radius of where it struck is either killed or stunned by the shock. Many fish rise to the surface and are picked up by the fisherman. An especially objectionable teature of this practice is the number of young fishes killed The method is prohibited ly law, hut rery little attention is paid to this enactment, as no effort is made to enforce it.

\section{POISONING.}

The law also prohibits the catching of fish hy means of stupefying drugs and plants placed in the water. but the practice is still followed in many places. It is called by the natives "hola hola." The ahuhu (crocer mirpuren), a poisonous weed which grows on the mountain side, is the plant generally employed. It is gathered and pounded np with sand, the latter to make it heavier so that it will sink in water. All over the reefs, running a short distance from and generally parallel to the shor', 


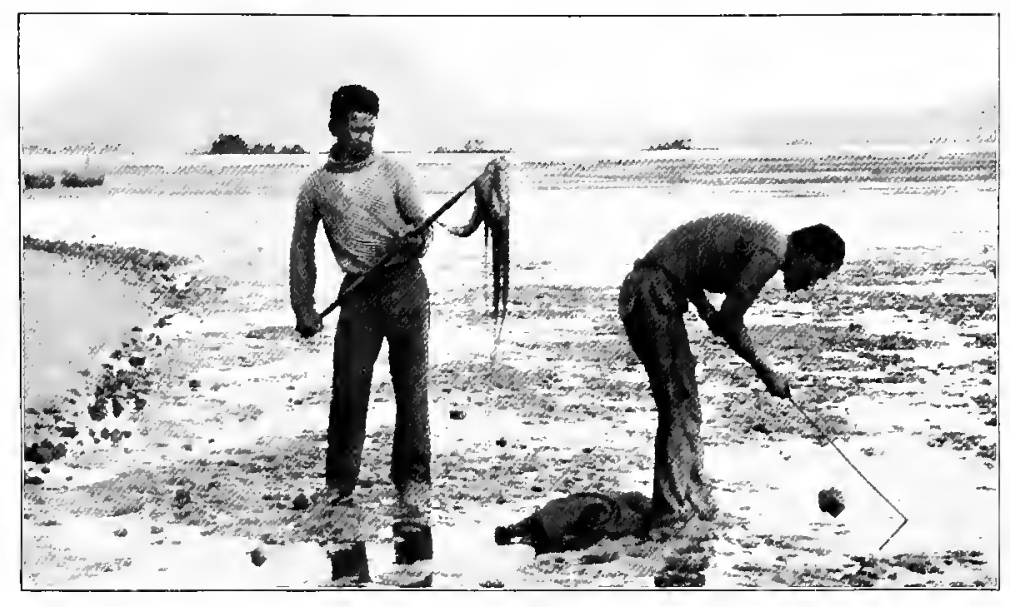

HEE (SQUID) FISHING WITH SPEAR.

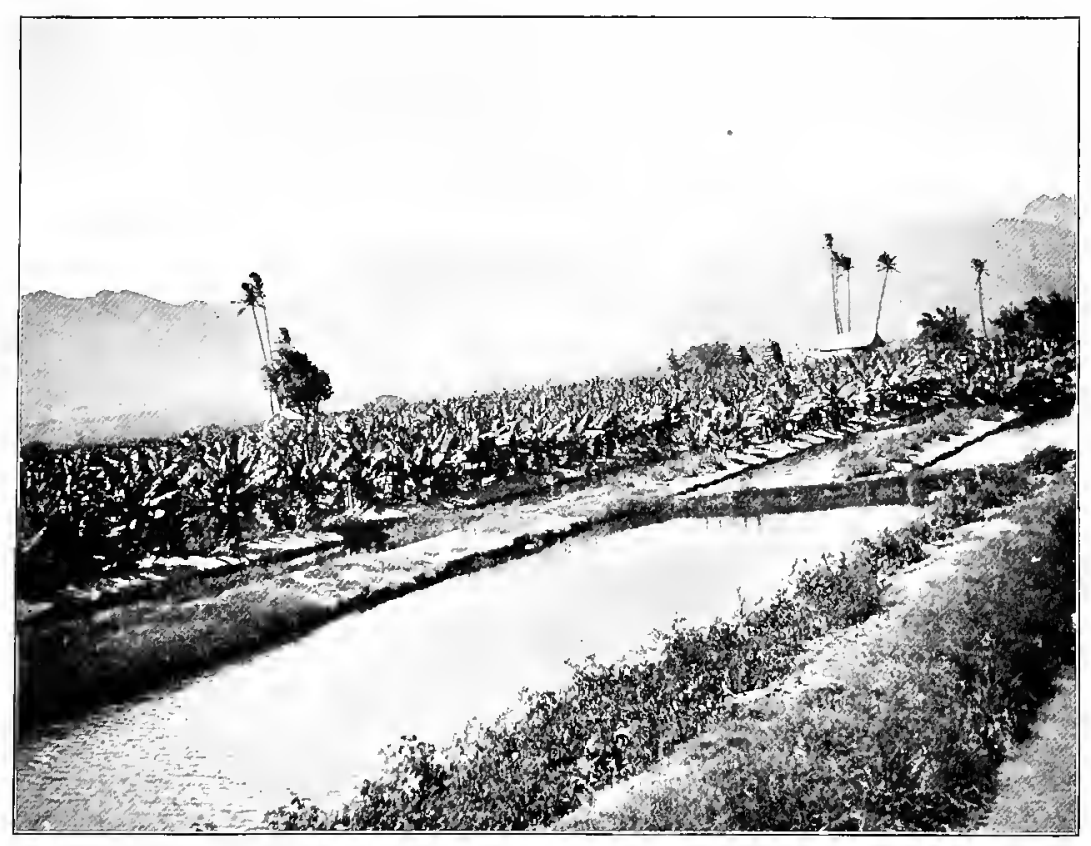

BANANA PLANTATIONS.

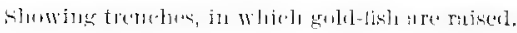



are numerous caves, boles, etc., which are the habitat of many species of fishes. The fishermen carly a small seine and a quantity of the poisonous mixture in one of their canoes, and when they arrive at the fishing ground set the seine around an isolated rock or the mouth of a cave. The escape of the fish from these retreats being thus prevented, the fishermen place some of the mixture in a small bag, and, diving to the botton, shake some of it in the holes. In about ten or fifteen minutes the fish seem to become stupefied and rise to the surface, whence they are taken into the canoe by means of small scoop nets. They soon recover fron the effects of the diug if allowed to remain in water.

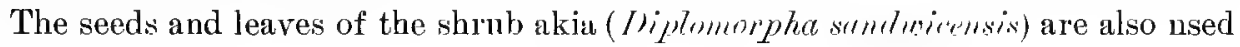
for this purpose.

\section{WEIRS.}

While weirs are not of conmercial importance in these islands, some are used in the mountain streams during the rainy season for taking the oopu, a small freshwater goby found mostly in these streams, and consumed principally by the fishermen and their families. During the dry season a platform of large logs, placed side by side, is built and placed in the stream at abont or just above high-water mark. Diring the rainy season the streans rise very high and the water becomes so muddy with the wash from the sloping ground adjoining the hanks that the oopus, who make their home- in water holes, under large rocks, etc., are driven out and carried downstrean by.the burrying waters. As these fish do not like muddy water, they endeavor to keep near the surface, which is comparatively clear, and are thus swept in immense quantities onto the platform, and from there into a ditch leading out to a plain, where they are gathered up in large quantities. At this season of the year the oopus are highly prized by the natives, on account of their very delicate flavor. This method of fishing is practiced mainly on the islands of Oahu and Kauai.

\section{TORCHING.}

Considerable fishing is done with torches at night. The torches are usually made of split hamboos secured at regular intervals with ki leares or twigs of the naio (Jymymnesendercensis). They are sometimes made of a number of kukui muts strung on rushes, or the stems of cocoannt leaves, which arr then wrapped with ki leaves so as to make the torch round like a candle. This latter kind will burn in almost any kind of weather. The ratives have a notion that if the toreh burns with a pale flame the fishing will be poor, but if it burns with a bright red flame it will be very good.

In shallow water the fish are frequently speared or taken in a small scoop net, the fisherman wading around with the lighted torch in one hand and the spear or net in the other.

Sometimes, while the fish is blinded or dazzled by the light, a scoop net is slipped in front of it hy one of the fishermen; a companion then gently tosses a stone just back of the fish, which causes it to dart forward into the net, and it is captured. This manner of fishing is called by the natives "lamalama."

Another popular method is stunning or killing the tish after they bave been attracted to the surface by the light of a fire in the bow of a boat. It is the pructice 
to put in the boat a can filled with inflammable material and corered with oil, row to a desirable place, and set fire to the fuel. The fish are fascinated or dazzled by the light and may easily he struck with a stick.

\section{SNARING.}

The use of the snare in fishing seens to be confined to Hawaii, its use on the other islands not being reported. Puhi (eels) and ula (crawfish) are the species usually taken in this manner.

In snare fishing for puhi (ahele puhi) the apparatus is a long stick with a noose arranged at the end, the string which works the noose reaching to the end of the pole. A bait made of almost any kind of pounded fish or crab is thrown into the water, especially around rocks, where the puhi lives in holes and erevices. The noose is slipped up close to one of these holes and when the puhi thrusts its head through in order to reach the bait, the line in the hand is pulled, drawing the noose tight to the end of the pole and choking the fish to death, after which it is drawn to the surface.

In fishing for ula (ahele ula), a long pole, to which dead bait has been tied about 3 inches from the bottom, is put down in the water in front of a hole in the rocks. As the ula comes out of its hole to get the bait another pole, with a crotch or fork at the end to both arms of which a noose is fastened, is slipped under its tail and suddenly jerked, tightening the noose, so that the animal can be brought to the surface.

FISHINI: WITH THE HANDS.

The native men, women, and children are perfectly at home in the water, spending a good portion of their time there, and they are exceedingly expert in diving and swimming. Frequently they catch various inhabitants of the water with their hands, and in some places this method of fishing las become quite an important source of revenue to them. It is a common sight, in the less densely inbabited regions, to see a stark-naked native man or woman crouching down in the shallow water and feeling around the coral and lava rocks for fish, papai (crabs), and opae (shrinp). Some of the fishermen dive to the haunts of certain species, and, thrusting their arms into holes or under rocks, bring out the fish one by one and put them into a bag attached, for the purpose, to the malo, or loin cloth. Opae, oopu (gobies), and gold-fish are frequently taken by women fishing with their hands in the fresh-water streams and taro patches, and form a considerable part of the food supply.

In fishing for hee (octopus) the native dives to the bottom, and, with a stick, pokes around in the small holes in which the animal lives. When he touches one it seizes the stick and allows him to draw it out of the hole. On reaching the surface the native seizes his captive with his hands and bites into its head, thus killing it.

The ula also is frequently taken hy the diver with his hands. The fishernan first provides himself with a small hag, which he attaches to his malo. His right band he carefully wraps up in a bag or a long piece of cloth, to prevent the ula fronı biting him, and, diving to the bottom, he feels around in the erevices and holes among the rocks, pulling out the nlas be finds and putting them in the bag, returning to the surface whenerer necessary. Frequently he will bring up two or three 
crawfish at a time. Occasionally the fishermen are severely bitten by puhis, which at times make their homes in the ula holes.

Nearly all the mollusks are gathered by hand. The opihi (limpet), which attaches itself to rocks, is detached by knives. The bêche-demer (sea slug), wana and ina (sea eggs) are also taken by hand.

The rarieties of limu (algre) which are eaten hy the natives are all gathered by hand, and this forms quite a profitable business for a number of women and children on the various islands.

\section{LINE-FISHING.}

Fishing with rod, hook, and line (called by the natives "paeaen") is not practiced to any considerable extent commercially, except for aku (bonito). In this fishery, mother-ot-pearl hooks, made from the shell of a mollusk, now quite rare, are used. These hooks are called pa, and as they glisten with an iridescence like the shimmer from the scales of the smaller kinds of fish on which the aku lives, no bait is needed.

The shell portion of the hook is barbed on the inner side with bone, and two tufts of hog's bristles are attached to the barbed end at right angles to it, for the purpose of keeping the inner side up, so that the shell will lie flat on the surface of

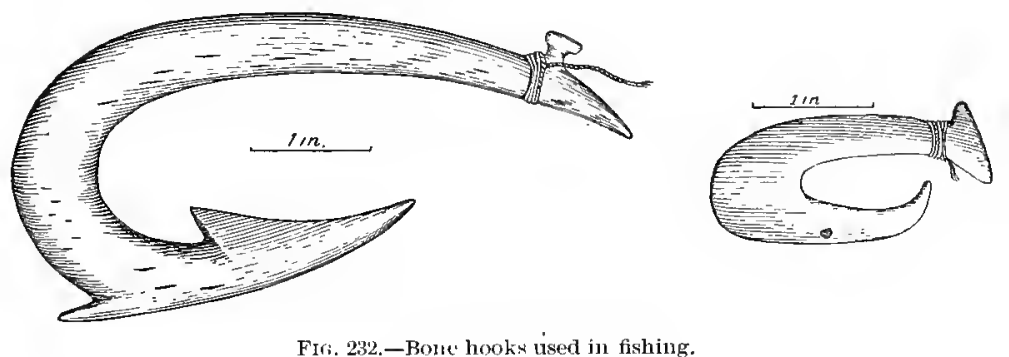

the sea. The bone portion of the hook in usully a dog tusk, but sometimes it is a piece of human bone, irory, or tortoise shell. An iron hook, with the curved portion bent over so far that the point runs almost parallel with the shank, is sometimes used. Brass hooks also are employed at times. In line fishing double canoes are generally found more convenient and much safer, as the fishing is done a considerable distance from shore.

On reaching the fishing-ground the fishermen locate the fish by watching the sea gulls, which will he seen hovering over the achools. It is the habit of the fish to 1'un against the tide, and as soon as the school has been sighted the canoes are worked around in front of it, and the fish are attracted toward the boat by means of a bandful or two of the small live bait thrown into the water. These small fish are usually the nehu, iiao, and the young of various species. There are three men in each canoe, but only one man in each engages directly in fishing, the others managing the canoe. These two men stand up in the stern of the boat, holding in their hands a bamboo pole about 12 feet long with a line of the same length attached, and the pearl hook tied to the end of this line. By a quick movement the line and hook are slapped violently on the surface of the watel and then drawn toward the boat. The aku are attracted by the noise, and seeing the glittering hook, which looks like a young tish, 
make a spring for it. As soon as the fish is hooked the line is swung up orer the fisherman"s head so as to make almost a complete revolution. It is rery necessary that the line should be kept taut, as. owing to the fact that the hook has but a slight barb, the fish would shake itself loose should the line slacken in the least. Is the hooked fish is deseribing this revolution the fisherman swing around to meet it as it nears him, bowing out his right arm. When the fish comes between his arm and side he closes them up and the fish is caught. unhooked, and clropped into the boat. If he perceires that the fish is coming toward him in such a wa that it will be difficnlt to hold it in the manner described, he moves out of range and allow: it to make another revolution, catching it on its return. The fishing must be done in from ten to fifteen minutes' time, as the school soon gets frightened and disappears.

In line-fishing for other species besides the aku, opae, earthworns, and live iry of tish are used :1 1 bait. Hooks of varying sizes and linds, made from irory, tortoise shell, and human and animal bones, are used. Frequently the fisherman, after baiting his hook from a handful of opae, bruises the remainder, and, wrapping it up in cocoanut fiber, ties it with a pebble on the line close to the hooks. The bruised matter spreads through the water when the line is dropped and serves to attract the fish to the vicinity of the hook.
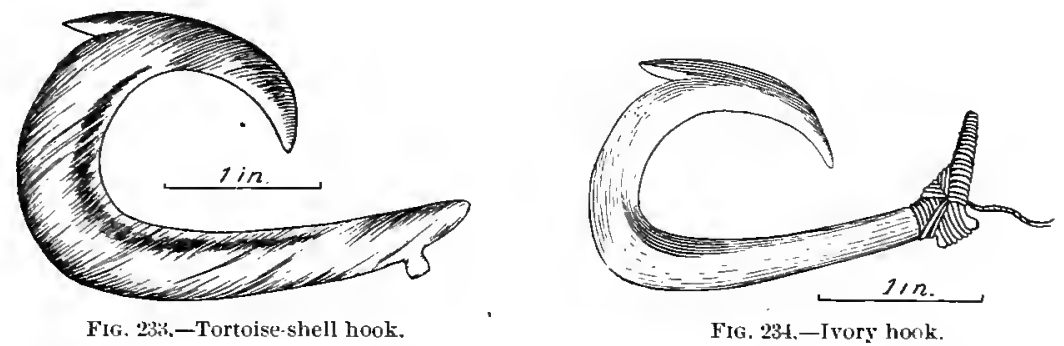

For hait in uhu fishing the gall bladder of the hee is dried and then cooked until it becomes a jelly, which is placed in a small calabash or lowl and tied to the hook as bait. A pole is nsed in this method of fishing.

In fishing for aama (crabs) from (litts or high rocks, a long bamboo pole with line, to the end of which is tied an opini, is used. The fisherman dangles this bait in front of the crab as it looks out from its home in the rocks, and the animal at onet seizes it. By a quick jerk the line is swung up and the aum caught.

In the deep-sea fishing hooks and lines are used without rods, except for the aku. Fishing is carried on here to depths as great as bou feet. The older native fishermen are familiar with all the reefs and rocky alevation for mites in every direction from the shore, and know well the different species of tishes to be found in each place. Frequently they go entirely out of sight of the lowlands and monntain slopes and take their bearings, for the purpose of determining from the relative positions of the different mountain peaks the reef or rock which is the habitat of the fish they are seeking.

On Hawaii an ingenious method of fishing for ulua is jlacticed. A long pole is planted on the shore in such a position as to lean decidedly toward the water. On the top of this a bell is arranged so that it will wwing clear of the top of the pole. 
In olden times a calabash with shells inclosed took the place now occupied by the bell. A block and fall is also attached to the pole close to the top, and a long line, with a hook at the end, is run through the block and allowed to float ont to sea, the land end being tied in a slipknot to the bottom of the pole and the surplus coiled at the foot. A small dead fish is used as bait. In order to attract the fish, puhi are mashed up with sand and thrown into the ocean. As soon as a fish is hooked his struggles cause the bell to ring, thus warning the fisherman, who at once runs to the pole and, loosening the slipknot, begins to play the fish. As the fish is too large and strong to haul in alive, it must be played nntil drowned.

In hand-line fishing from canoes in deep water, a line of about $\frac{8}{8}$-inch cord, with a lava stone weighing several pounds as a sinker, is used hy the natives. A little above the sinker, and for a distance of about 6 feet, there run out from the line little bamboo canes about a foot in length, in a horizontal position, and from the outer ends of these canes dangles a short piece of line, with a hook at the end. The bait is put over the point of the hook and the upper portion of it tied to the shank by means of two small threads hanging from the line and tied just above the hook. This line is used in water as deep as $2(n)$ fathoms. As soon as the sinker reaches the bottom the native, by a peculiar jerk, disengages the stone and diaws the line about a fathom from the bottom, where it is allowed to remain until a certain number of bites have been felt, when it is drawn to the surface, the fish removed, the hooks rebaited, a new sinker put on, and the line run overboard again. Ulaula is the principal species captured thus.

In deep-sea fishing the Japanese generally use but one hook on a line, attached to the end of if.

In fishing for mahimahi (dolphin) the Jipanese use a rope about 2,000 feet in length. At intervals of 60 feet are attached branch lines about

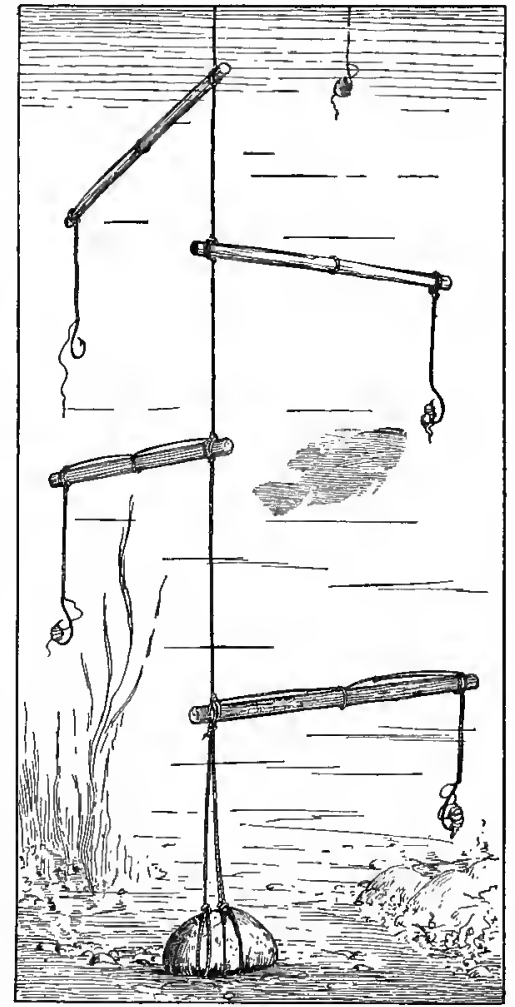

FIG. 235,-Deep-sea fishing line. 60 feet in length, with a hook on each. Akule are used as bait. The line is paid out from the boat, the main line being kept on the surface by bnoys made from the cotton tree, while the branch lines hang downward. The line is set in the morning and taken up at noon, the fishermen lying off in their boats in the meanwhile. This fishing is carried on about 10 miles offshore.

A line used principally for catching kole has at the end a piece of lead, at each end of which is attached a short line with a hook. The gall of the hee, prepared in one of the numerous ways given under" the section headed "Pait," is used for bait. This manner of fishing is called by the natives "okilo hee." 
The native is a great lovel of the hee, and has a number of methods of capturing it, one of the most interesting of which is with the cowrie shell. One or more cowrie shells of the Manritiuna or Tiger virieties are attached to a string. When only one is used, an oblong pebble about the size of the shell is tied to the face of it, a hole is pierced in one ent of the back of the shell, a line is passed through, and after being fustened here, allowed to hang a few inches below the shell, to which a hook, whose point stands almost perpendicular to the shaft or shank, is attached. Only shells with small red spots breaking through a reddish-brown ground have an attraction for the hee, and it will not rise to any other kind. Shells which have suitable spots but unsuitable background are given the desired hue by steaming them over a fire of sugar-cane husks.

On arriring at the fishing ground the fisherman in pursuit of hee either chews up and spits upon the water a mouthful of candlenut meat, to render the surface glassy and clear, or he uses the water glass, which is described below. He drops the shell into the water, and by means of the line swings it back and forth over a place likely to be occupied by a hee. The greedy animal perceires the shell, shoots out an arm, and seizes it. If the bait is attractive, after a few moments' hesitation

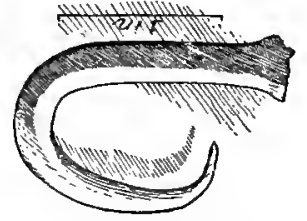

FIG. 236.-Hook matle from iron nit.

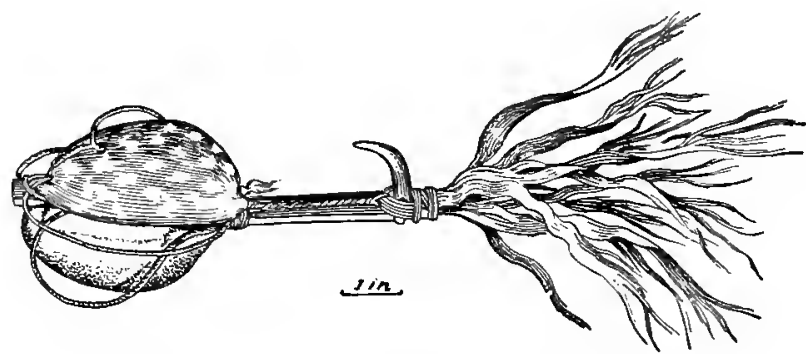

FIG. 237.-Cowrie hook with shell for catehing her.

another arm is placed around it, and then another, until at last the animal withdraws itself entirely trom its hole and hugs the shell closely to its body, oblivious of ererything else. The fisherman then draws it rapidly up through the water, and when it raises its head at the surface, pulls it over against the edge of the camoe and delivers a blow hetween the eyes with a club which is generally fatal. Owing to the hee's quickness with its eight tentacles or arms, the fisherman has to be very rapid in his movements, as the animal would he no mean antagonist should it have an opportunity to seize him with its arms. The natives say that a number of persons hare lost their lives in struggles with the octopus. This method of fishing is called by the natives "Lawaia hee me ke leho" (squid-catching with cowrie).

A cowrie shell, with a metal hook laid across the month of the shell and fixed in position with melted lead, is sometimes used in fishing for hee; and, again, a line with a piece of lead attached to the end in a horizontal position, a hook with the point up being lashed to one of the ends of the lead, is employed.

Water glasses are frequently used along the Hawaiian coast. An oblong, square box, with a piece of glass fixed in the bottom, is put on the water, with the glasi end downward, and the fisherman, by placing his face in the open end, can distinctly see the botton, although the surface may be broken with ripples outside of the water 
glass. The water glasses now in use could be nuch improved if the box were made wide enough to allow the entrance of the whole head instead of merely the face, it being easier to see when the sunlight is completely cut off from the glass. A water glass similar to that used in the sponge fisheries of Florida would be very effectivean ordinary bucket with the bottom removed and a pane of glass substituted.

In fishing fol honu (turtle) a flat stone is used, with two hooks lashed to the opper part and rumning out in opposite directions. This is attached to a long line. Hee also are occasionally caught with this style of apparatus.

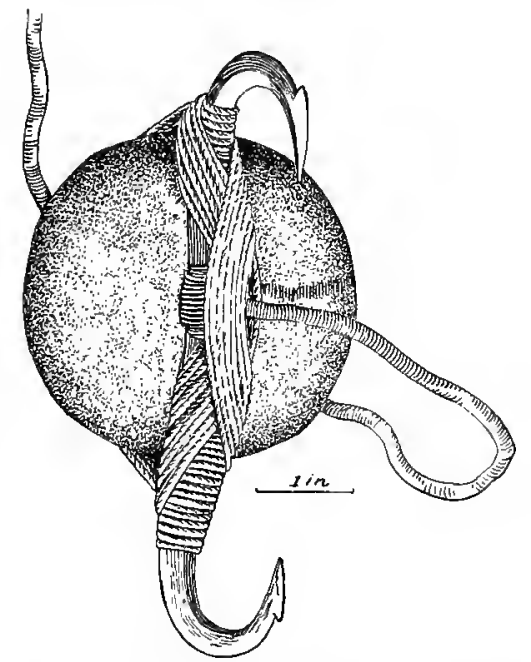

FIG. 238.-Hooks nsed in eatching turtle and squid.

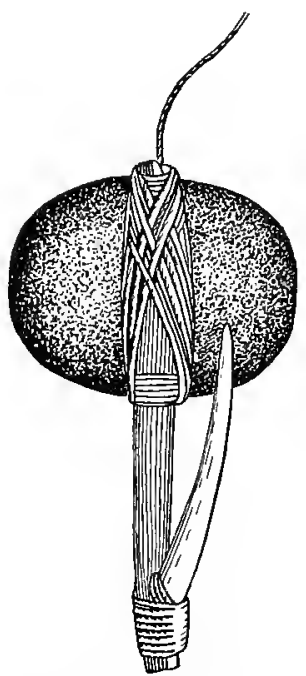

FIG. 239.-Hook with ivory barb and wooden shank.

In fishing for papai (crabs) the younger natives frequently use short lines with a small wooden buoy at the top and a piece of bait (meat, fish head, or any other dead bait) at the end. These are set in shallow water close to the shore, and are frequently lifted by children, who wade ont to them and grasp with their hands the crabs clinging to the bait before they becone frightened and let go.

\section{SHARK-CATC'H1NG.}

The shark has always occupied a mique position in not only the religious but in the daily life of the native. This, however, is treated elsewhere in this report, and only the methods of fishing for sharks will he considered here.

The natives distinguish five species of sharks frequenting Hawaiian waters. The mano kihikihi (hammer-headed shark) and the lalakea (white-fin) are considered edible. The hammer-headed shark is the one most frequently seen in the markets. The others are the mano kanaka (man shark), the shark god of the ancient Hawaiians; the mano, a large white shark, and the ninhi, the largest and fiercest of all. The last two are but rarely seen in Hawaiian waters. The niubi is said to be seen a Jong way off at night hy the bright greenish light of its eyeballs. It is much feared by the natives.

The mano kihikihi and the smaller lalakeas are generally taken with other fishes in gill nets, seines, or bag nets. The larger lalakea and the other species are taken 
with hook and line, as no net would be strong enough to hold them. Shark hooks are generally carved from a piece of hard wood, with a piece of sharp-pointed bone lashed to the end of the hook to form the tip. But few of the hooks seem to have a harb, and it speaks well for the dexterity of the fishermen that they succeed so well in fishing with these.

sometimes the native seeks the shark in cores and caves below the surface after the fish has gorged itself and is sleeping with its head forced into the sides of its

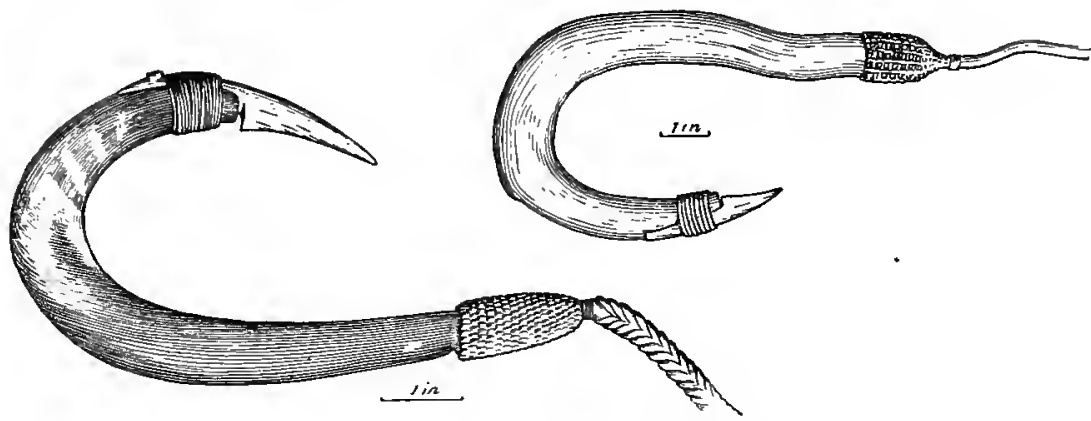

FIG. 240.-Wooden shark hooks, with bone points.

resting place. The diver gently slips a noose around the tail of the shark, which is then hauled np and dispatched. Experts hare been known to capture six or eight sharks in one day in this manner.

In the olden times the catching of the niuhi was made a great event, but there bas been no regular fishery for it for nearly one hundred year's. The following account of the manner of its capture is especially interesting: a

The common kind of shark was caught in vast quantities, and the liver, with a little of the flesh, was wrapped in ki leaves and baked underground, then from fifty to a hundred of the largest single and double canoes were liaded with baked meat and large quantities of the pounderl roots of awa, mixed with a little water, ancl contained in large gourds. The fleet would sail many miles out to sea in the direction in which the niubi is known frequently to appear. Arrived at a comparatively shallow plare, the canoe containing the head fisherman and the priest and the sorcerer-who was supposed to be indirpensable-would cast anchor; meat and the baked liver would be thrown overboard, a few bundles at a time, to attract sharks. After a few days the grease and scent ef cooked meats would spread throngh the water many miles in radius. The niuhi would almost al ways make its appearance after the third or fourth iay, when bundles of the baked meats were thrown as fast as it could swallow them. After a while it would get comparatively tane and would come up to one or other of the canoes to he fed. Bundles of the liver with the pounded awa wold then be given to it, when it woulil become not only satiated, but also stupefied with awa, and a noose was then slipped wer its head, and the fleet raised anchor and set sail for lowe, the shark following a willing prisoner, the people of the nearest canoes taking care to feed it on the same mixture from time to time. It was led right into shallow water till it was stranded and then killed. Every part of its hone and skin was supposed to confer unflinching bravery on the possessor. The actual captor-that is, the one who slipperl the noose over the niuhi's head-would also, ever after, be alway's victorions. The shark's natural home is, perhaps, in the warmer waters of the equator, as the (iilbert Islanders, now here, make the assertion that it ir very frequently seen and captured at their group. The tradition lere is that it is only seen just after or Iluring a heavy storm, when the disturbed waters perhaps drive it away from its uatural haunts.

\footnotetext{
a Hawaiian Fisherief and Methods of Fishing, with an Arrount of the Fishing Implemonts used by the Natives of the Huwaijun lslands. By Mrs. Emma Metealf Beckley.
} 
The use of human flesh as bait was in great vogue among the Hawaiian chiefs. It was cheaper than pig, was equally acceptable to the shark, and gave the chief an opportunity to kill anyone whom he disliked. The victim was cut up and left in a receptacle to decompose for two or three days. Kamehameha I was a great shark hunter and kept his victims penned up near the great heiau (temple) of Mookini, near Kawaihae, Hawaii.

\section{NEW FORMS OF APPARATUS PROPOSED.}

It is probable that the beam trawl could be used to advantage in the deeper waters around the islands. This apparatus, which is an immense bag, with wide flaring mouth, the bag running to a point at the end, is worked from the deck of a sail or steam ressel. Long cables are attached to the sides of the month of the bag, and the trawl is dropped overboard while the ressel is in motion. It sinks to the bottom, and as the vessel moves forward is drawn along the bottom, scooping up everything in its path. When it has been down a sufficient length of time the ressel is brought up into the wind, the trawl raised to the deck, where it is emptied, and then dropped overboard for another trial. Sharks are very destructive to nets used in the deeper waters, and also eat the fish out of them; with the beam trawl this would be obviated.

Pound nets made of fine wire could he used to advantage on the leeward side of the islands aud in the bays. Netting could not be used, as the sharks and larger fishes would tear it to shreds while struggling to get in or out.

Fyke or hoop nets would probably prove profitable in the bays and rivers. They could be set and left without further attention until it was couvenient for the fisherman to raise them.

BAIT.

Catrling of bait.- The natives generally use live bait in the line fisheries, and their' method of catching it is rather interesting. In the morning a medium-length finemesh seine is loaded in the canoe or canoes, each of which contains two or three men, and is paddled about $t^{0}$ or 50 feet from the shore. One man is left on the land, and he runs along the rough, rocky shore with a small pail of dried opae, of which he takes out a few at intervals, and, after chewing in his month a few moments, spits them into his hand and throws them on to the surface of the water a short distance from the shore. If no fish rise to the bait thrown out it is quite certain none is there, and he runs on a little farther and repeats the operation. When firh rise to the surface and nibble at the bait he signals to the canoemen, who immedictely paddle in close to the spot, and all but one, who is left in the boat to maneuver it, drop overboard with the seine and sweep it around the spot, inclosing the fish.

On most of the islands the nehu is the principal species of bait fish taken, while on Hawaii the piha is also used for the same purpose. The young of many other species are taken in these seines and used as bait, to the great havoc of the general fisheries.

Bait used.-Live opae are very frequently used for bait in the line fisheries.

All species of young fish are used as bait, both alive and dead, though the former are preferred. In fishing for mahimahi (dolphin) young akule (called agi by the Japanese) are used. 
The natives are rery expert in the preparation of palu, or baits, from various substances. In making these a small section of the sharp end of a cocoanut shell, about $1 \frac{1}{2}$ inches in height, and a small stick of hard wood are used, in the same manner as a mortar and pestle.

A number of methods of preparing such baits, with the ink bag of the hee as the principal ingredient, were given to me hy Mr. .Joseph Swift Emerson, of Honolulu, who has made a thorough study of the native customs. Alaala behe (the ink bag of the common octopus) is roasted on the coals in the leaves of a ki plant, and when well cooked is ground into a paste in the mortar. Usually it is flavored with something that is supposed to attract the fish. Great care is taken in compounding the mixture, and every fisherman has his favorite recipe. The following are some of the more common mixtures used, alaala hehe forming the base in every case:

1. Pound up a little alaalapuloa root in the mortar, throw away the fiber, leaving only a few drops of juice in the mortar, then mix in the alaala hehe, working it thoroughly with the pestle.

2. Mash up a red pepper and throw seeds and pulp away, leaving only a few ilrops of juice adhering to the mortar.

3. Olitain juice from puakala (the prickly plant, the thistle) seeds. Mix in a little salt and proceed as in $N$ \% 1.

t. The same with ilima flowers and salt, always using an exact number of flowers, say 4 or 8 . The fishermen have a superstitious idea that if an odd number is used it will have no force.

5. The same with salt and young noni leaves slightly roasterl.

6. The same with salt and maile kaluhea.

7. The same with salt and leaves of the paina (poha-cape gooseberry).

8. The same with salt and very young leaves of koko.

9. The same with the bark from the root of pilo (plant growing near the seashore with beautiful flower of foul smell).

10. The same with salt and the bark from root of naunau.

11. Mix with kukui (candle nut) nuts, well roasted, the kukui nuts to be well ground first and then the alaala hehe to be worked in.

12. Mix with old hard cocoanut burnt to a crisp, a little kukui nut rarely done and salt.

13. Mix with a little cinnamon.

14. Mix with fruit of mokihana, which grows on Kauai.

15. Mix with a few drops of brandy or other intoxicating liquors.

16. The same with Perry Davis pain killer.

17. The same with kerosene oil.

18. The same with tobacco juice.

19. The same with juice from ahuhu seeds.

20. Mix with salt and coal from burning a little mahuna kapa.

21. Iix with salt and coal from the sugar cane of the variety known as ainako.

20. Salt the alaala hehe before roasting.

The bait, when prepared, is applied to the tip of the hook and is very attractive to tish. Those caught with it are usually small ones found near shore.

In tishing for opelu, cooked squash, pumpkin, papaia, and bananas, also tish ground up fine and mixed with sand, are employed.

The following additional varieties of bait are used in fishing for different species: Kukui and cocoanut meat baked together in equal quantities, chewed bread fruit and taro, opae dried and pounded, wana with shell broken to expose the meat, halfroasted sweet potatoes, raw ripe papaia, pounded papai, fresh and dried opae, earthworms, opihi, the gall of the hee, puhi pounded up tine with sand, nehu, ilao, akule, scraps of neat, fish heads, etc.

Buit brores. - As live bait is generally used in the fisheries, suitable boxes for keeping it are necessary. The following are the styles in general vogue:

When two canoes are joined together for aku (bonito) fishing, the buit box is swung beneath the cross trees and lashed there. It is about 20 feet long, 2 feet high 
the whole length, and about 16 inches wide in the center, running to a sharp point at each end. On the outward trip about two-thirds of the box is submerged, and as the sides are perforated, water is admitted freely. On the return, however, as the box is empty, it is unlashed and placed on top of the cross pieces, in order not to impede the progress of the canoe. After the aku fishing is over the box is either bauled out on the land until the next season, or moored close to shore in a sheltered position and used for keeping bait temporarily, but is not taken out to the grounds, as it is too big and unwieldy for one canoe to handle. Much smaller boxes of the same general style are frequently employed, also square and oblong boxes of varying sizes, perforated, or with slats set close together.

The Japanese frequently use small boxes about a foot long by 8 inches wide by 8 inches deep, perforated on the sides and ends with small holes. These are attached to the boat by a short piece of twine and allowed to tow alongside.

Some of the Japanese also carry bait in one of the smaller of the wells in the bottom of their sampans.

\section{VESSEL FISHING.}

In view of the fine fishing grounds in deep water and on the reefs and shoals within reasonable distance from the islands, it is surprising that there are no vessets engaged in fishing. Several attempts have been made to establish vessel fisheries, but for various reasons they have met with failure.

The last attempt was in 1898, when a number of persons in Honolulu formed a company and, at a cost of $\$ 6,600$, had the gasoline schooner Mulolo built to engage in this business. She was fitted out with six seines and one bag net, at a cost of $\$ 1,000$, and carried a crew of four men. The fishermen were Japanese, who were hired at Honolulu. They had their own boats and lines, and the schooner towed them to the fishing grounds. A station was established at Palaau district, on Molokai, and an old fish pond there was purchased with the purpose of cleaning it out and using it for catching fish which came in through the entrance. It was the intention of the company to hire fishermen on the islands to work the nets, while the Japanese would engage in line-fishing, and the schooner would make regular trips to Honolulu with the catch. 'The fishing was to be done on the reefs about the west and south sides of the island of Molokai.

Difficulty was at once encountered in the unreliability of the Japanese crew, who would go to Lahaina and other places and sell their catch. Another crew was collected, composed largely of white men, mostly beach combers, and they were taken to the fishing groumds, to work the nets principally. This plan also failed, owing to ignorance of the business on the part of the crew, and a third effort was made, this time with a crew of native Hawaiians and South Sea islanders secured at Lahaina. Twelve of these men were put on the island of Lanai and supplied with boats, nets, lines, and provisions. After a few hauls the vessel left for Honolulu with the catch, the understanding with the fishermen being that they were to continue fishing to secure a second cargo during her absence. When the vessel returned, bowever, half of the fishernen had deserted and the few remaining were carried to Lahaina. The whole business was abandoned in August, 1899, after the failure of an effort to get another gang on Maui. 
The cuptain of the vessel says there was no lack of fish at any time, and if the fishermen could have been properly trained to the work the experiment would have been a brilliant success. Most of the fishing was done with trolling and hand lines, as the nets would not work well on the coral reefs, frequently tearing, and the numerous sharks about the reefs also did much damage to them.

\section{FISH PONDS.}

The most interesting of the fishery resources of the islands are the fish ponds. This is the only place in United States territory where fish ponds are found on such an immense scale and put to snch general and beneficent use. The time of the building of many of them goes baek into the age of fable, the Hawaiians, for instance, attributing the construction of one of the most ancient, the deep-water fish pond wall at the Huleia River on Kanai, to the Menehunes, a mythical race of dwarfs, distinguished for cunning industry and mechanical and engineering skill and intelligence. Many of the very old ponds are still in practical use and look as though they would last for centuries. As the ponds were originally owned by the kings and chief's, it is very probable that most of them were built by the forced labor of the common people. There is a tradition anong the natives that Loko Wekolo (Wekolo pond), on Pearl Harbor, Oahu, was built about two hundred and fifty year's ago, and that the natives formed a line from the shore to the mountain and passed the lava rock from hand to hand till it reached the shore where the building was going on without once touching the ground in transit. As the distance is considerably over a mile, this is significant of the density of the population at that time.

The ponds are found principally in the bays indenting the shores of the islands, the common method of construction having been to build a wall of lava rock across the narrowest part of the entranee to a small bay or bight of land and use the inclosed space for the pond. Ponds were also built on the seashore itself, the wall in this case being run out from two points on the shore, some distance apart, in the shape of a half cirele. Most of the Molokai fish ponds were built in this manner. A few were constructed somewhat interior, and these are filled by the fresh water streanis from the mountains or by tidal water from the sea carried to them by means of ditches. Most of the interior ponds are on Oahu, near Honolulu. The Nomilo fish pond at Lawai, on Kauai, is formed from an old volcanic crater with an opening toward the sea across which a wall has been built, and as the opening is below the surface of the sea the tide plays in and out when the gates are opened.

In the sea ponds the walls are about 5 feet in width and are built somewhat loosely, in order that the water may percolate freely. The interior ponds have dirt sider generally, although a few have rock walls covered with dirt, while others have rock walls backed with dirt. The sea ponds generally have sluice gates which can be raised or lowered, or else which open and close like a door. In the interior ponds there are nsually two small bulkheads with a space about 8 feet square between them. Each of these has a small door which usually slides up or down. When the tide is coming in both doors are opened and the fish are allowed to go in freely. At the turn of the tide the doors are closed. When the owner wishes to remove any of the fish he generally opens the inner door when the tide is ebhing. The fish rush into the narrow space between the bulkbeads, from which they are dipped out by 


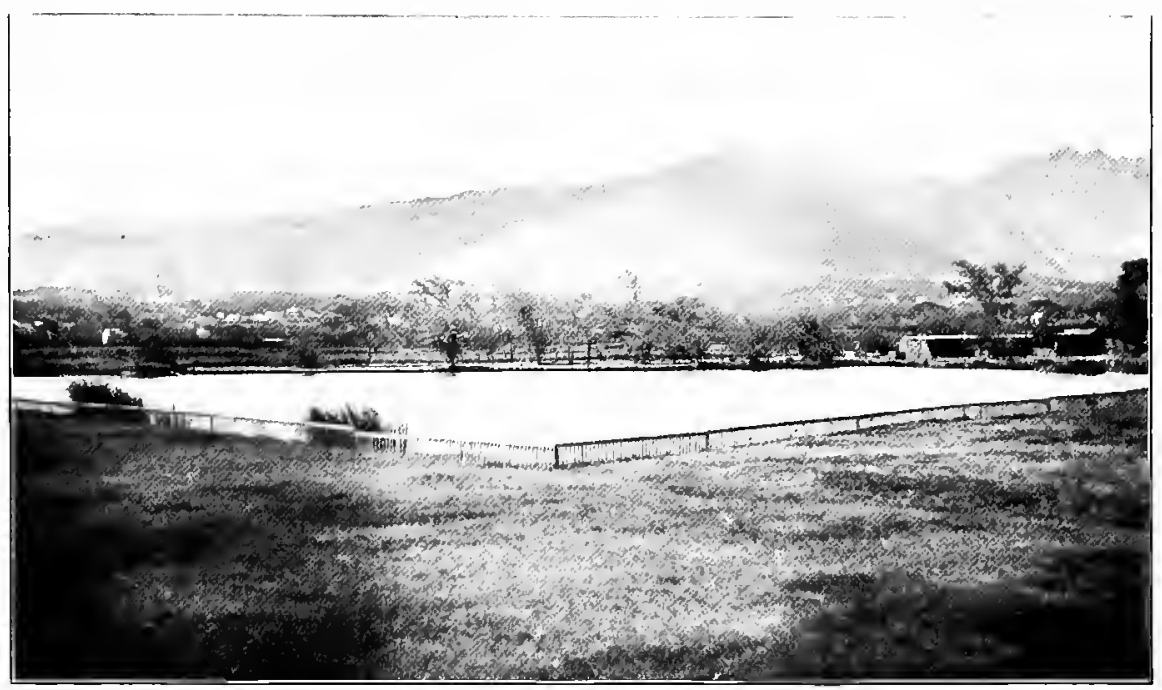

INTERIOR FISH POND, WAIKIKI, OAHU.

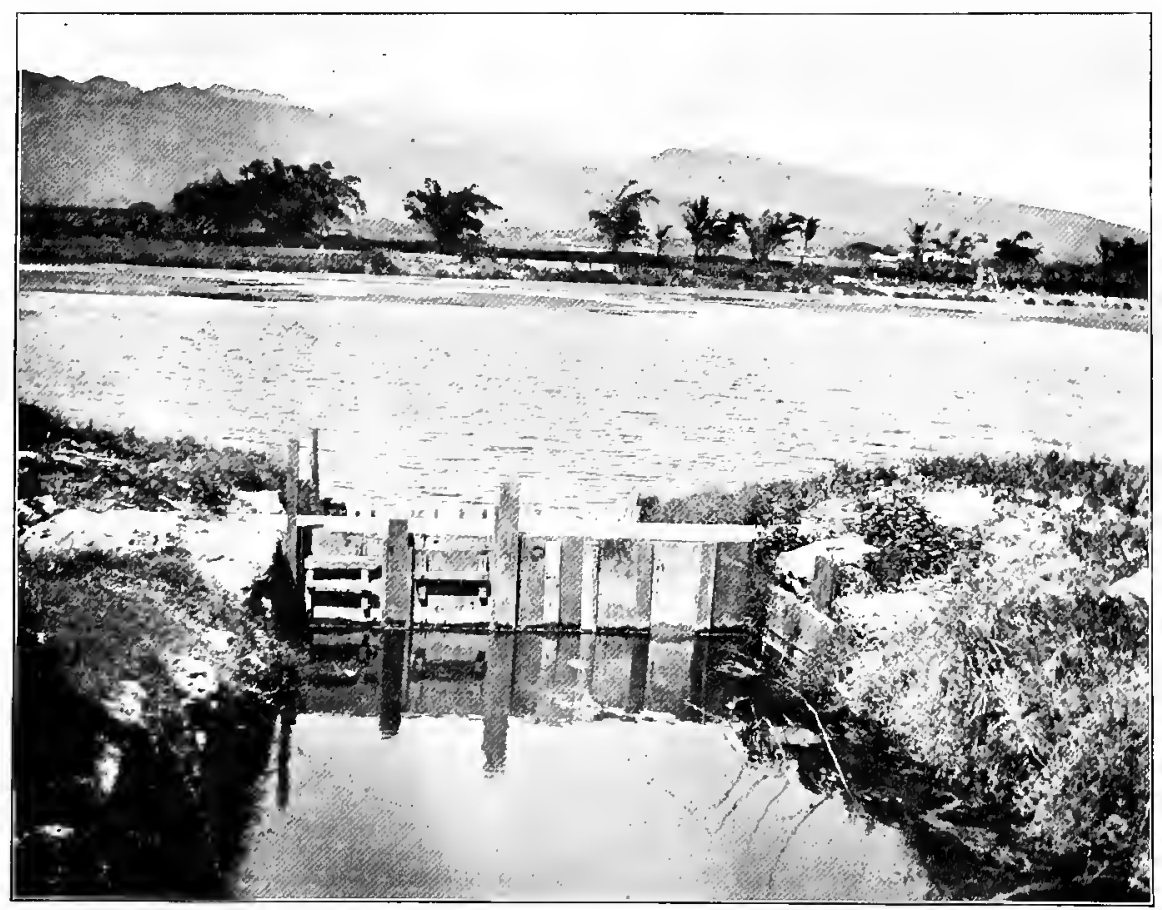

SLUICEWAY LEADING INTO INTERIOR FISH POND, WAIKIKI, OAHU. 

means of hand dip nets. In the sea ponds the gate is opened when the tide is coming in and rlosed when it turns.

There is usmally a small runway, built of two parallel rows of loosely piled stones, from the gate to about 10 feet into the pond. As the fish congregate in this runway when the tide is going ont, it is very easy to dip ont the supply needed tor market. Seines and gill nets are also used in taking fish from the ponds, a method which is easr, owing to the shallowness of the ponds.

The sea ponds usually contain only the ama-ama, or mullet, and the awa. In the fresh and the brackish water ponds gold fish, china-tish, oopu, opae, carp, aholehole, and okuhekuhe are kept. Practically no attempt at tish-culture is made with these ponds. Besides the fish which cone in through the open gates at certuin seasons of the year, the owner ustally has men engaged in eatehing young amaana and awa in the open sea and hays, and transporting them alive to these enclosures, where they are kept until they attain a marketable size, and longer, frequently, if the prices quoted in the market are not satisfactory. It costs almost nothing to keep them, as they find their own food in the sea ponds. It is supposerl that they eat a fine moss which is quite common there.

There are probably not more than one-half the number of ponds in use to-day that there were thirty years ago. There are numerous reasons for this, the principal ones being the following:

1. The native population is rapidly disappearing, and where there were prosperous and populous rillages in the early years of the last century there is practically a wilderness now. Owing to this depopulation, there is no sule for fish in the inmediate neighborhood of the ponds, the only market possible, owing to the difficulty in transporting any distance without the use of ice. The ponds have thus naturally been allowed to go to decay, the walls breaking down from the action of storms, and the sea filling them with sand if they are located on the immediate shore. This condition of affairs is especially prevalent on Molokai.

2. Two of the important crops of the islands are rice and taro. As both must be grown in a few incbes of water, and are very protitable crops, a number of the interior ponds were turned into rice fields and taro patches. Oahu has shown the greatest changes in this respect.

3. On Hawaii ponds were filled up by the volcanic lava flows of 1601 and 1859. The Kamehameha fish pond, which was tilled up in this manner in 1859, was said to have been the largest on the islands. Only traces of it are now to be found on the beach.

4. At Hilo, on Hawaii, some ponds, mostly quite small, are so tilled with the water hyaeinth that it is no longer possible to use them for fish. This yeur a few of the best of these were cleaned out, but as there is very little profit to be made from them, and their ownership is in dispute, there is but little desire to do much to build them up.

5. Other ponds have been filled up to make way for building operations and for other purposes. This is especially true of ponds in and around Honolulu and Lahaina. There used to be a number of fish ponds on Lanai, but they have all been allowed to fall into decay. 
A number of ponds are kept up by their owners merely as private preserves, as it were, the fish taken from them being either consumed by the owner's household or given to friends. Such ponds are scattered all over the islands.

The following is a rough list of the fish pouds still in existence, or traces of which remain, together with their area and a statement so far as possible of their present condition. There is no great cluin to accuracy in this list, as many of the ponds are in inaccessible regions of the islands, and in such cases the writer was ohliged to depend upon others for reports as to their present condition:

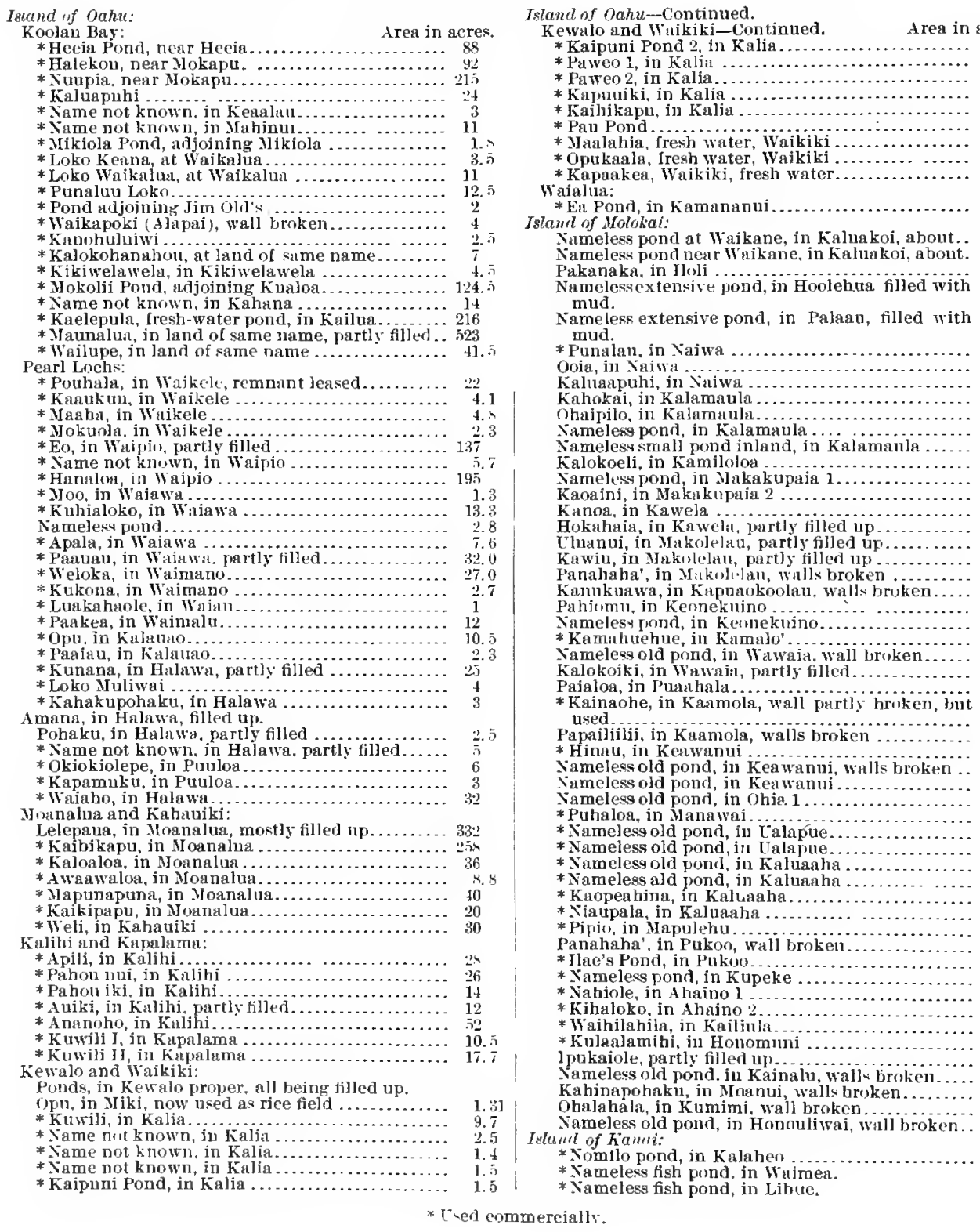

Namelessextensive pond, in Hoolehta filled wjth Tameless extensive pond, in Palaau, filled with

Ooia, in Naiw:

(n)....

Samelesg pond, in Kalamaula 


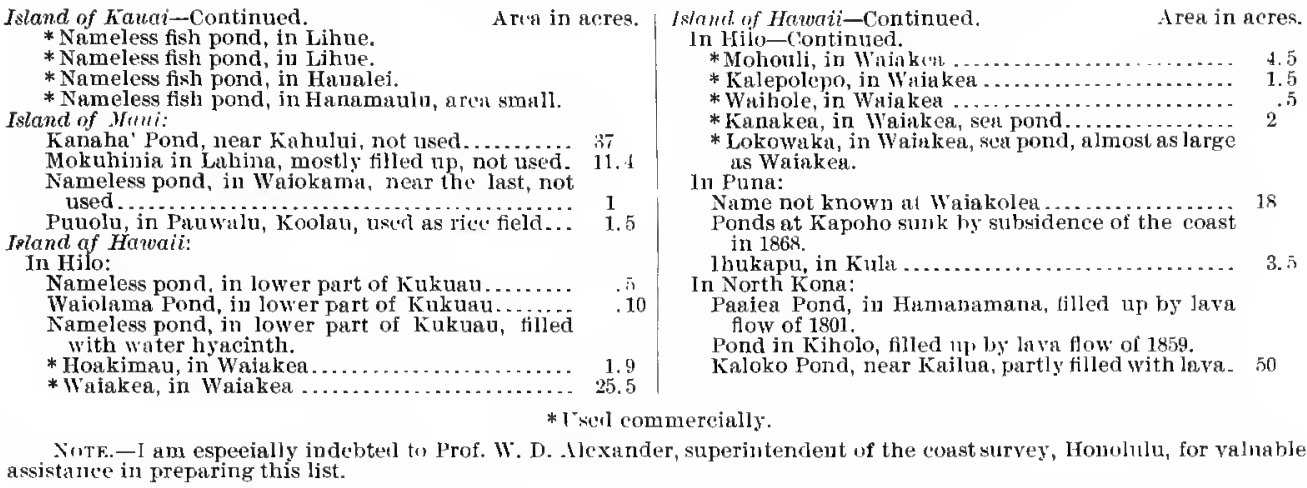

Nintz.-I am espeeially indebtel to Prof. W. D. Alexander, superintendent of the coust survey, Honolulu, for valuable assistince in preparing this list.

Owners of ponds rarely have much to do with the practical working of them, usnally leasing them to Chinese. Most of the ponds on Oahu are controlled by two Chinese merchant firms in Honolulu, who work in close harmony. They take particular care that the Honoluhn market shall never become overstocked with amama and awa, and are thus able to command ahmost any price they please during certain seasons of the year when amaama are not to he had elsewhere. The effect of this is felt severely hy the white population, who are the principal consumers of the amaama. The maintenance of private ponds should be encouraged as much as possible, as they are of great assistance in keeping up a regular wupply of certain species at all seasons of the year.

The tables following show, for the year 1900, by islands, the number and nationality of the persons enployed, the number and value of the fish ponds and boats, the number, kind, and value of apparatus employed in the ponds, the catch hy species, and the catch by apparatus and speries, together with the values of same.

The island of Oahn leads in every particular, haring 74 fish ponds, valued at $\$ 148,850$, and employing 142 persons. The total investment for the island is $\$ 150,761$. Molokai is second, with 15 ponds, valued at $\$ 11,425,27$ persons comployed, and a total investment of $\$ 11,709$. Kauai and Hawaii follow in the order named. The total investment in the pond fisheries for all of the islands is $\$ 168,443$.

The total catch for Oahu is 560,283 pounds, valued at $\$ 139,714$; Molokai is second, with 91,919 pounds, valued at $\$ 2,4+81 \%$. The total catch for all the islands is $6 \times 2,46 \pm$ pounds, ralued at $\$ 14 i, 1141$, of which 485,531 pounds, worth $\$ 119,202$, are ama-ama.

The gill net is the leading form of apparatur used, rielding 404,537 pounds, valued at $\$ 97, \$ 14$. Dip nets, seines, and scoop nets follow in the order named. 
Table showing, by islands, the persons employed, the number und whe uf fish ponds, boats, and apparatus uscd in the pond fisheries of the Havainan Islands in 1900.

\begin{tabular}{|c|c|c|c|c|c|c|c|c|c|c|}
\hline \multirow{2}{*}{ Items. } & \multicolumn{2}{|c|}{ Hawaii. } & \multicolumn{2}{|c|}{ Kauai. } & \multicolumn{2}{|c|}{ Molokai. } & \multicolumn{2}{|c|}{ Oahu. } & \multicolumn{2}{|c|}{ Grand total. } \\
\hline & No. & Value. & No. & Value. & No. & Value. & No. & Value. & Sin. & Value. \\
\hline Fish ponds. & 4 & 1,200 & 6 & $\$ 5,100$ & 15 & $\$ 11,425$ & 74 & $\$ 148,450$ & 99 & $\$ 166,575$ \\
\hline $\begin{array}{l}\text { Fishermen: } \\
\text { Americans..... } \\
\text { Chinese....... } \\
\text { Hawaiians.... }\end{array}$ & $\begin{array}{l}1 \\
8 \\
2 \\
\end{array}$ & & $\begin{array}{l}6 \\
5\end{array}$ & $\cdots \cdots$ & $\begin{array}{r}20 \\
7 \\
\end{array}$ & & $\begin{array}{r}113 \\
29 \\
\end{array}$ & & $\begin{array}{r}1 \\
147 \\
43 \\
\end{array}$ & \\
\hline Total & 11 & $\cdots$ & 11 & ....... & 27 & ......... & 142 & $\ldots .$. & 191 & $\ldots$ \\
\hline $\begin{array}{l}\text { Boats: } \\
\text { Rowboats.... } \\
\text { Whaleboats.. }\end{array}$ & \pm & 20 & 6 & 70 & 1 & 100 & 21 & 500 & $\begin{array}{r}31 \\
1\end{array}$ & $\begin{array}{l}590 \\
100\end{array}$ \\
\hline Total & 4 & 20 & 6 & 70 & 1 & 100 & 21 & 500 & 32 & 690 \\
\hline $\begin{array}{l}\text { Apparatus: } \\
\text { Haul seines..... } \\
\text { Gill nets ......... } \\
\text { Dip nets } . . . . . \\
\text { Seoop nets..... }\end{array}$ & 5 & 25 & 6 & 58 & $\frac{1}{14}$ & $\begin{array}{r}50 \\
134 \\
\cdots \\
\cdots \\
\end{array}$ & $\begin{array}{r}5 \\
55 \\
40 \\
10 \\
\end{array}$ & $\begin{array}{r}170 \\
1,100 \\
134 \\
7 \\
\end{array}$ & $\begin{array}{r}6 \\
80 \\
40 \\
10 \\
\end{array}$ & $\begin{array}{r}220 \\
1,317 \\
134 \\
7 \\
\end{array}$ \\
\hline Total . & 5 & 25 & 6 & $5 x$ & 15 & 184 & 110 & 1,411 & $\cdots$ & 1,678 \\
\hline Grand total... & $\cdots$ & 1,245 & & 5,208 & $\ldots$ & 11,709 & & 150,761 & $\ldots .$. & 168,943 \\
\hline
\end{tabular}

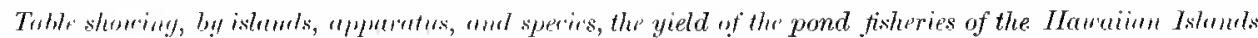
in 1900 .

\begin{tabular}{|c|c|c|c|c|c|c|c|c|c|c|}
\hline \multirow{2}{*}{$\begin{array}{l}\text { Apparatus and } \\
\text { species. }\end{array}$} & \multicolumn{2}{|c|}{ Oahu. } & \multicolumn{2}{|c|}{ Kauai. } & \multicolumn{2}{|c|}{ Molokai. } & \multicolumn{2}{|c|}{ Hawaii. } & \multicolumn{2}{|c|}{ Grand total. } \\
\hline & Lbs. & Value & Latos. & Vulue. & Lbs. & Value. & Lbs. & Value. & Lbs. & Yalue. \\
\hline $\begin{array}{l}\text { Seines: } \\
\text { Ama-ama.......... } \\
\text { Awa ............. }\end{array}$ & $\begin{array}{l}36,000 \\
13, \text {, } 11\end{array}$ & $\begin{array}{r}\$ 9,000 \\
3,128\end{array}$ & & & $\begin{array}{l}8,000 \\
\ldots \ldots \ldots\end{array}$ & $\begin{array}{c}\$ 2,000 \\
\ldots \ldots\end{array}$ & & & $\begin{array}{l}44,000 \\
13,511\end{array}$ & $\begin{array}{r}\$ 11,000 \\
3,124\end{array}$ \\
\hline Total . & 49,511 & 12,128 & $\ldots \ldots \ldots \ldots$ & 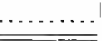 & 8,000 & 2,000 & ....... & & 57,511 & 14,128 \\
\hline 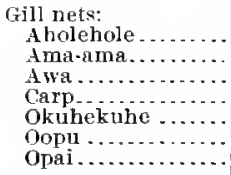 & $\begin{array}{r}187,362 \\
102,192 \\
\ldots . \\
\ldots \\
492 \\
310\end{array}$ & $\begin{array}{r}46,840 \\
25,74 \\
2 . \\
31 \\
31\end{array}$ & $\begin{array}{r}21,800 \\
5,109 \\
1,500 \\
\ldots \ldots\end{array}$ & $\begin{array}{r}93,270 \\
511 \\
150\end{array}$ & $\begin{array}{r}x 1,700 \\
=, 219\end{array}$ & $\begin{array}{r}20,425 \\
555\end{array}$ & $\begin{array}{r}200 \\
1.473 \\
\ldots \ldots \\
180 \\
\ldots\end{array}$ & $\begin{array}{c}830 \\
368 \\
\cdots \ldots \\
\cdots \\
18 \\
\cdots \cdots \\
\cdots\end{array}$ & $\begin{array}{r}200 \\
292,335 \\
109,520 \\
1,500 \\
180 \\
492 \\
310\end{array}$ & $\begin{array}{r}30 \\
70,903 \\
26,613 \\
150 \\
18 \\
74 \\
31\end{array}$ \\
\hline Total & 290,356 & 72,492 & 28,409 & 3,931 & 83,919 & 20,980 & 1,853 & 416 & $\mathbf{4 0 4 , 5 3 7}$ & 97,819 \\
\hline $\begin{array}{l}\text { Dip nets: } \\
\text { Ama-ama......... } \\
\text { Awa } \ldots . . . . \ldots \ldots \\
\text { Gold-fish } \ldots \ldots \ldots\end{array}$ & $\begin{array}{r}140,428 \\
70,521 \\
80\end{array}$ & $\begin{array}{r}35,107 \\
17,630 \\
10\end{array}$ & & & & & & . & $\begin{array}{r}140,428 \\
70,521 \\
80\end{array}$ & $\begin{array}{r}35,107 \\
17,680 \\
10\end{array}$ \\
\hline Total ..... & 211,029 & 52,747 & & $\ldots$. & ....... & $\cdots \cdots$ & $\ldots \ldots \ldots$ & $\ldots \ldots \ldots$ & 211,029 & 52,747 \\
\hline 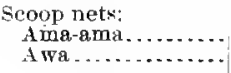 & $\begin{array}{r}8,768 \\
619\end{array}$ & $\begin{array}{r}-192 \\
155\end{array}$ & & & & & & & $\begin{array}{r}8,768 \\
619\end{array}$ & $\begin{array}{r}2,192 \\
155\end{array}$ \\
\hline Total ..... & $\because 1, \operatorname{lin} 7$ & 2,347 & & & & & & $\cdots$ & $9,3 \times 7$ & 2,347 \\
\hline Grumd total... & 560,283 & 184,711 & 28,409 & 3.931 & 91,919 & 22,980 & 1,853 & 116 & 682,464 & 167,041 \\
\hline
\end{tabular}

The data shown in these tables sre given in the general statintical talles shown clsewhere.

\section{PREPARATION OF FISHERY PRODUCTS.}

With the exreption of a small quantity dried for their home usc. and, on several islands, for market, the fishermen sell their catch in a fresh condition. The Chinese and Japanese, however, buy considerable quantities of fish from the fishermen and 
prepare them nsually hy drying. Most of this work is done on Hawaii, the district of Kona being' especially noted for its dried fish.

The nehu, while one of the smallest of the many species found around the islands, is the one usually dried by the dealer's. Large pirces of bagging are spread on the ground, exposed to the full ray's of the sun, and the nehu, in round condition, are laid on these. When the drying is completed they ar' placed in tubs and carried around the islands on "arts, and are generally sold to the Chinese and Japanese for about 25 cents per pound.

The piha, a fish about the same size as the nehu, is frequently prepared in the same way on Hawaii.

The general method of preparing the larger species is as follown:

The fish are split open from the back, exrept in the case of the opelu, which is opened from the belly, and the entrails removed. The fish are not washed before salting, as it softens them and they are apt to spoil. The larger fishes are scored along the sidr. They are then lightly salted and put in a container, where they are allowed to remain orernight. In the morning they are taken out, the salt shaken off of them, and they are put in a pan of fresh water, wher the salt is thoroughly washed off, after whirh they are placed upon rude rackis or boards, covered with cocoanut leaves, and allowed to remain until the sun thoronghly dries them. They are put under cover at night. When thus prepared, they will keep for some time. Opelu, amaama, akule, and aku are the species nsually preserved in this manner.

In preparing the ahi (albacore) the fish is cut up in squares of ahout a pound each, which, except in localities where hlow-flies are troublesome, are scored. The pieces are kneaded in salt until almost as round as a haseball and are then put out to dry.

A considerable quantity of amama was dried in Kanai during 1!\%1, but it was all condemned when it reached the Honolulu market, owing to the alleged careless manner in which it had lwen prepared. It is very probable that with proper care a considerable trade could be built up by the fishermen who live in localities from whence fresh fish can not be shipped.

Limu ( $\left(l_{\left.! / i^{*}\right)}\right.$.- - The natives are great lovers of limu, and the gathering of it for market forms quite a profitable business for number's of women and children. It is prepared by rolling it into balls 2 or 3 inches in diameter, squeezing the water ont, and sprinkling lightly with salt. Many varieties of algre are found around the islands, but only a few are used for food. Among these are limu lipoa, limu eleele, limu pakaeleawaa, limu mananea, limu lipeepee, limu lipakai.

FISH MARKETS AND THE HANDLING OF FISHERY PRODUCTS.

There are six fish-market houses on the islands, one each at Honolulu (Oahu), Hilo (Hawaii), and Wailuku (Maui), and three at Lahaina (Mlui). In addition, peddler's with small carts and on the backs of jackasses retail fish throughout the sections of inhabited country which are not convenient to the markets or to the fisheries. There is great room for development in this phase of the business, however, as the inhahitants of some of the more inaccessible villages rarely have an opportunity to purchase fresh fish. 


\section{HOXOLTLO.}

Previous to 1551 the only market place for tish. regetables, ete., was an open space in the vicinity of the present location of the Honolulu Iron Works. In 1551 the first regular market house for the sale of fishery products was erected on the wharf, and a law passed May 12 of the same year prorided that this building and the adjacent gronnds seaward of Pulaholaho, belonging to the Goverument, should be the public warket. Br a later act. under date of June 25,1555 , the space between the old flour mill and the water, at the west end of Queen street, was reserved for a market.

In 1590 the present market house was erected on the square bounded by Alakea, Richards, Halekauwila, and Allen streets, at a cost, including the ralne of the land, of $\$ 155,000$. It is built almost entirely of irou, and is open on all sides except one, where there are a number of closed booths for the sale of fruit, regetables, meat, etc. In design and workmanship this building is one of the best in the United states. The stalls all have wooden sides with marble tops. There is alwars plenty of fresh water. and the drainage facilities are of the rery best. Its location, abont 100 yards from the wharf where the Japanese fishermen land, also is convenient. The market is orned by the territorial gorernment. which pars the salaries of the officials in charge of it. The market keeper. who is also the fish inspector, receives a salary of 830 per month as keeper and $\$ 60$ per month as inspector. There are also an assistant market keeper at $\$ 25$ per month, an assistant fish inspector at $\$+0$ per month, and one laborer at $\$ 1.25$ per day. All fishery products must be sold in the market house, as bawking through the streets of the city is not permitted. All fish must be inspected before thes go upon the stalls, and the market is open erery week day and up to 9 a. m. on Sunday.

There are 20 stalls for the sale of fresh fishery product., with rents rarying from $\$ 15$ to $\$ 30$ per month, according to the locatiou. Only 15 of these stalls were occupied in 19n. Ot this number 11 mere run by Chinese, 3 by Japanese, and 1 by natives. the total number of persons emplosed, exclnsive of the market officials, being 40 Chinese, 6 Japanese, and 2 natives. The usnal wage of the help is $\$ 12$ to $\$ 15$ per month, including food and lodging. In addition, 6 stalls were occupied by 6 natice women on saturday, and sometimes sunday morning, for the sale of limu (algx). The charge for these tables is 50 cents on saturday and 25 cents on sunday. Three stalls also were devoted to the sale of dried fish from the island of Hawaii during most of the week, and were run by three natire women. On a few days in the week when fish are scarce certain of the dealers sell also pickled California salmon, for which thes pay an additional license fee of $\$ 10$ per year.

The fishermen bring their catch to the market at whaterer hour is conrenient to them, and the dealer's sell for them on a basis of 10 per cent commission. Fish brought in prior to noon must be sold before the market closes the same erening, but if brought in after noon and not sold before night thes can be kept in a coldstorage house close by, at a cost to the owner of 2 cents per pound, and be placed on the stalls again the next morning; in that erent, howerer, they must be distinguished by a small placard bearing the words "iced tish." The inspector is directed 
by law to pass upon all fish before they are placed upon the stalls, and can condemm any tainted fish either then or afterward. It is the custom to make frequent inspections of the fish after they go upon the stalls, as they soon become tainted in that trying climate. Owing to the cost of ice, none is used around the market house.

The larger fish are dressed, but the smaller ones are sold round. There is no loss in dressing, however, as the head, entrails, etc., are sold. All except gold-fish, and sometimes china-fish, are sold dead.

In addition to the fresh fish sold in 1900 , about 72,000 pounds of pickled salmon, with a selling value of $\$ ?, 000 ; 9,125$ pounds of dried fish, with a selling value of $\$ 1,141$, and about 18,000 pounds of limu, worth $\$ 2,340$, were marketed.

The leaves of the ki plant (Tetsin teminalis), which are 10 to 15 inches long and oblong in shape, and are cut with a part of the stem left on, are used for wrapping fish in the markets. The fish is laid across the narrow part of the leat, the end of which is turned tightly over it and wound around the stem, and then tucked in, the stem forming a handle by which to carry the package. The wrapping is done so skillfully that it rarely works loose. With the larger packages two or three leares are used. The ki plant grows on the nountain side near Honolulu, and is cut and brought to town by natives. The dealers pay about 25 cents for a package of 100 of the leaves.

The market at Honolulu is the principal one on the islands and has the largest population tributary to it. Quite complete weekly reports of the fish sold are made to the board of health by the inspector.

The most noticeable feature in this narket is the extremely high price charged for tishery products, exceeding any other retail market of the United States, and possibly of the world. But few of the better grade of fishes sell for less than 25 cents per pound, some selling for as much as 35 cents per pound. All fish are sold by number, but they have been reduced to pounds in the general statistical tables presented herewith, and the prices computed accordingly, so as to conform to data collected in other sections of the United States. Ama-ama, the conmonest species, sell for an average of 25 cents per pound, or $8 \frac{1}{3}$ cents each, and ula (crawtish) for 20 cents each, or 10 cents per pound. In The Polynesian, of Honolulu, under date of September 7,1844 , amaama are quoted at 37 to 50 cents per dozen, other fish 3 to 6 cents per pound, and ula at $6 \frac{1}{4}$ cents each, showing quite a difference between the prices then and now.

There are a number of reasons given for this condition of affairs, the principal ones being as follows:

1. Owing to the impossibility of keeping the catch in a fresh condition more than 24 to 48 hours, the fishermen try not to take more than can easily be sold, and, because of this, gluts-the principal causes of low prices-rarely occur.

2. Owing to the insufficient transportation facilities there is but little opportunity to bring to a market where there is a scarcity the overplus of another. The island of Oahu has advantages over the others in this respect, as there is a railroad which skirts the western and northern shores for nearly one-half the circumference of the island. This permits of the rapid and cheap transportation of fish from the various places along the railroad to Honolulu, and has been of great assistance in 
dereloping the fisheries of these places. The fishermen on the eastern and southern sides of the island, however, are still compelled to bring their eatch to the market in carts and as a result bring in only the higher-priced species.

3. The fish ponds are prineipally in the hands of two Chinese firms of Honolulu, and these firms, by working in harmony and having eontrol of the principal souree of supply of the amama and awa for a considerable part of the year, are enabled to keep up the prices for these speries.

4. The Japanese now do the greater part of the line firhing for the Honolulu market, and they hare organized a company, including nost of the fisbermen of that nationality, with the object, among other things, of securing as high prices as possible for their catch.

5. The indiscriminate use of fine-meshed seines has undoubtudy caused a falling off in the catch, although to what extent is a rather difficult problem to solve, owing to the lack of statistical data for previous year's.

6. Shortly after the fall of the monarchy a boom in the islands, especially in Honolulu, eaused the prices of everything to rise. The price of sugar has largely controlled everything on the islands, and as this has been quite high for some rears it has accordingly affeeted the priees of other commodities. This boom is on the wane now, and it is probable that conditions will become more normal in the course of a few year's.

\section{HILO.}

The market house at Hilo, which is owned by private interests, was opened for business on April 1, 1899. During 1900 the number of stalls occupied was 27 , the rents of which varied from $\$ 5$ to $\$ 15$ per month. These stalls were not oecupied continuously, however, dealers frequently giring up their business after a week or a month. There are 32 stalls in all. The persons employed around the narket numbered 22 Chinese, 18 Japanese, and 14 natives. During the summer of 1901 a syndieate of Chinese and. Jajanese bought up the stalls and began to take advantage of their position by shutting out the other dealers and eompelling the fishermen to sell to them at a low price. There was of course no limit to what they could charge the townspeople, as fish could not be sold on the streets. As a result, a number of fishermen carried their catch by carts to Olaa, about 11 miles away, and established a temporary market there.

The territorial govermment leased the market in August, 1901, and this broke up the combination. In inspeetor was appointed also, who will have eomplete charge of everything about the market. Previously there was no inspection, and large quantities of tainted fish were foisted upon the people.

As at Honolulu, erery effort is made to dispose of the catch the same day that it comes in, as no ice is nsed. Owing to the heavy surf close to the market house the fishing hoats can not land there, and ale compelled to go to Waiakea, a suburb of Hilo, about a mile away. The tishing boats usually land here during the morning and are innediately hoarded hy the lealers, who begin to dicker for the eateh. I'ben a boat with a large catch enmes the confusion is excessive. as Japanese, Chinese, Portuguese, Hawilian, English, and variations of these languages are hurled baek and forth, each man trying to outdo every other in the amount of noise made. 
Errything is on a cish basis, the successful buyer counting down the money at once and lemoving the fish, which are taken to the market by carriers with baskets slung wer their shoulders on poles, and by carts. The principal selling time at the market is in the afternoon, after the dealers have returned from Waiakea.

\section{WAILUKU.}

The market house at Wailuku is a small building' with only 5 stalls, which are run by 2 Chinese and 5 matives, and is owned ly a private individual. The market house, with land, is valued at abont $\$ 1,500)$. Nost of the fish sold here are brought from Kahului, a few miles away, while some ana-ama rome from the island of Molokai. The narket has no government supervision, which it neerls.

\section{LAIIAINA.}

The principal market house at Lahaina is owned by the government and is valued at ahout $\$ 6,000$, inchuding the land. It contains 6 stalls, which rent at $\$ 3$ per month. These were r'un in 1900 hy 1 Americun, 4 . Japanese, and 4 natives. Close ly are 2 private stalls, which were operated by 4 Japanese. In addition, in 1900 , there were 2 private fish markets in town, with a total valuation of $\$ 650$. These contained 6 stalks, which were run by 4 Chinese, 4 Japanese, and 4 matives. The greater portion of one of these was destroyed hy fire in the early part of 1901 and has not since been rebuilt.

There is no inspector at Lahaina, although one is very nuch needed, as the sale of tainted fish, particularly hy the Japanese, is quite common. Lahaina is the principal market for the disposal of the fish taken hy the tishermen on Molokai and Lanai.

The number of persons employed at these markets has not been shown in the general statistical tables in this report.

\section{THE WHOLESALE TRADE.}

The wholesale trade in fishery products is carried on in two cities-Honolulu and Hilo - and, owing to the constant demand for such articles fron the sugar plantations, is very profitable. A few of the plantations purchase their supplies direct, and these are not included in the following table. None of the firms is engaged exclusively in this business, all being principally wholesale grocery firms.

Honolulu leads in the wholesale trade in erery particular. In 1900 she had y firms, employing 73 persons, and a total investment, including wages paid, of $\$ 348,380$ in 1900 , while Hilo had s firms, with 30 employees, and a total investment of $\$ 161,7+5$, including wages.

Salmon is the principal product handled, followed by sardines, cod, oysters, lobsters, mullets, and shrimp, in the order named. The total value of all products bandled amounted to $\$ 359,965$. 
Table showing the wholesale trade in fishery products of Hawaiian Islands in 1900.

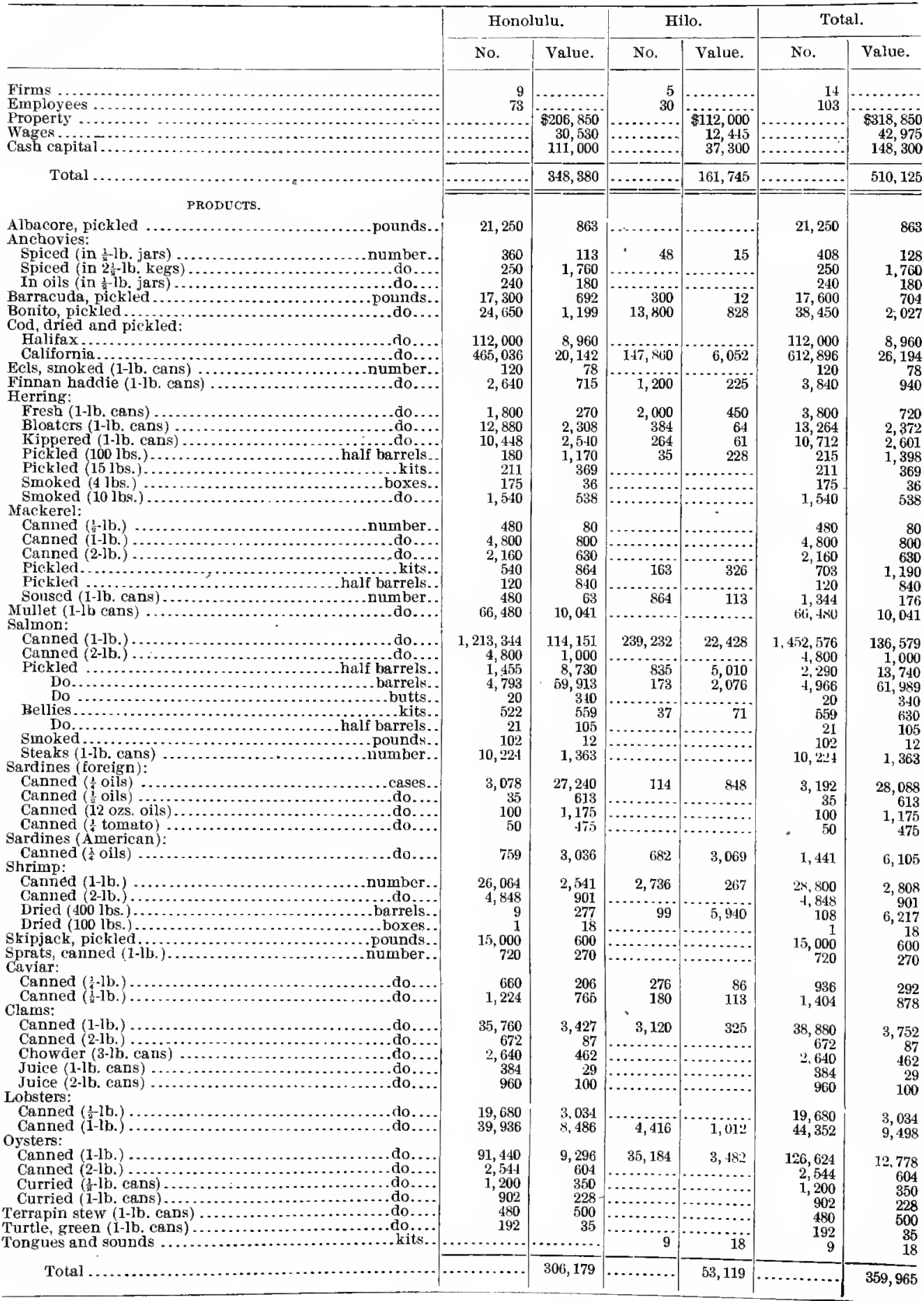


Fresh fish is also brought to Honolulu from San Franciseo in the cold-storage rooms of the regular steamers. Until last year all of this fresh fish came from Victoria in the Canadian vessels, as the San Francisco steamers had no cold-storage rooms.

During 1900 the following products (not shown in the wholesale table) were retailed in a firesh state in Honolulu:

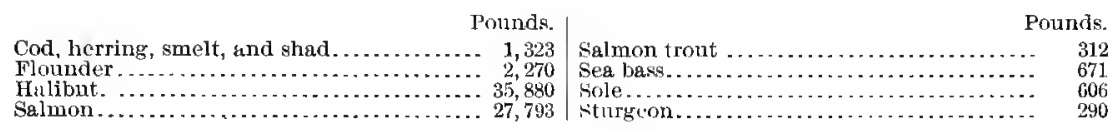

FISHERY IMPORTS.

As the domestic fisheries have not been sufficiently developed to supply the large home demand, great quantities of foreign goods must be imported to make up the deficiency. These imports consist principall ${ }_{Y}$ of salted, smoked, dried, and canned goods, and are very diverse, owing to the unusual mixture of population. The Chinese and Japanese are the principal consumers of dried abalone, cuttle-fish, oysters, seaweed, and shrimp; the dried and salted cod is preferred by the Portuguese and Porto Ricans, while the natives are great lovers of salmon.

An attempt should be made to introduce the abalone, as it would probably thrive well on the rocky reefs and sea walls.

The raising of sugar is the principal industry of the islands, and as large numbers of libborers are required on the plantations, which are frequently not accessible to markets where fresh fishery products can be obtained, prepared products must be supplied.

The United States has always led in the matter of imports, San Franciseo of late years being the jrincipal port from which goods were shipped to the islands. Previous to the opening of the transcontinental railroads most of the shipments came either by vessel to Colon, thence by rail across the Isthmus of Panama, and by vessel from there to the islands, or by means of ressels which came around the Horn. Many of the whalers which rendezvonsed at the islands previous to $\mathbf{1 8 7 5}$ also brought ont considerable cargoes of general merchandise, including cod, mackerel, and other products of the New England fisheries, which met with a ready sale or barter to the natives and the white inhabitanti.

On January 30,1875 , a reciprocity treaty was concluded between the Hawaiian Kingdom and the United States. This treaty went into effect September 1, 1876, and was to continue in force for seven years, and for twelve months after notice of its termination. By its terms, in compensation for the free entry to the United States of certain natural produets of the islands, notably sugar, the Government permitted the free entry, among many other articles, of fishery products of American origin. As the same products from other countries wer'e compelled to pay an ad valorem duty of 10 per cent, this gare the United States an inmense advantage. By mutual consent this treaty continued in force until the islands were annexed to the United States on June 14, 1900, and proved of great mutual benefit. For some few years previous to 1876 the sugar industry of the islands bad been languishing on account of the duty imposed by the United States on shipments from this sonree. As a result of this depression and the conseruent inability of the people to bny imported goods, shipments of dried and salted fishery products dropped off until in 
1566 they amounted to only $\$ 17 . \$ \$ 1 . \$ 1$. L'nder reciprocity the imports rapidly increased, until in 1899 they amounted to $\$ 20.374 .83$, the greater part of which came from the United Sitates.

The following table shows the rahe of dried and salted fish imported into the islands from 1865 to June 14, 1900 :

\begin{tabular}{|c|c|c|c|}
\hline Year. & $\begin{array}{l}\text { Value of ary } \\
\text { and salt fish } \\
\text { imported. }\end{array}$ & Year. & $\begin{array}{l}\text { Value of dry } \\
\text { and salt fish } \\
\text { imported. }\end{array}$ \\
\hline $\begin{array}{l}865 \\
865\end{array}$ & $\begin{array}{r}\$ 98,224.63 \\
31,609.04 \\
47,805.61 \\
23,025.69 \\
20,903.08 \\
39,463.15 \\
32,439.51 \\
19,420.60 \\
18,383.52 \\
23,524.30 \\
\mathbf{1 4}, 781.74 \\
\mathbf{1 7}, 891.81 \\
26,594.82 \\
47,206.95 \\
66,978.38 \\
35,276.72 \\
63,576.95 \\
65,701.27 \\
96,630.12\end{array}$ & $\begin{array}{r}1884 \ldots \ldots \\
1885 \\
1886 \\
1887 \\
1888 \\
1889 \\
1890 \\
1890 \\
1891 \\
1892 \ldots\end{array}$ & $\begin{array}{r}\$ 74,751.85 \\
70,977.01 \\
97,148.12 \\
96,759.83 \\
88,673.17 \\
90,555.23 \\
105,962.91 \\
102,073.65 \\
78,839.93 \\
89,865.02 \\
89,270.24 \\
66,780.80 \\
80,341.34 \\
109,827.68 \\
96,670.23 \\
120,374.83 \\
59,820.27 \\
2,268,129.98\end{array}$ \\
\hline
\end{tabular}

FISHERY EXPORTS.

Owing to the large home demand, the islands have exported but little. The bêche-de-mer and sharks' fins hare usually been shipped to ('hina or to the Chinese residents in California, while the gold-fish were sent to California, where they were probably used for ornamental purposes. The exporting was carried on in a small way during the period from 185.3 to 1866 , though in some year's nothing was shipped.

The following table shows, by years, the exports of each species:

\begin{tabular}{|c|c|c|c|c|c|c|c|c|c|}
\hline \multirow{2}{*}{ Year. } & \multicolumn{2}{|c|}{ Bêche-de-nier. } & \multicolumn{4}{|c|}{ Sharks' fins. } & \multicolumn{2}{|c|}{ Gold fish. } & \multirow{2}{*}{$\begin{array}{c}\begin{array}{c}\text { Dried } \\
\text { fish. }\end{array} \\
\text { Boxes. }\end{array}$} \\
\hline & Pounds. & Cases. & Pounds. & Cases. & Boxes. & Packages. & Number. & Pounds. & \\
\hline 1853 & & & 100 & & & & & & \\
\hline $\begin{array}{l}1854 \ldots \ldots \ldots \\
1861 \ldots \ldots \ldots\end{array}$ & 6,507 & $\ldots$ & 200 & . & - & $\cdots$ & & & \\
\hline $1862 \ldots \ldots \ldots$ & 5,809 & .......... & 50 & & .......... & $\cdots$ & $\ldots$ & & - \\
\hline $1863 \ldots \ldots \ldots$ & 5,500 & $\ldots \ldots \ldots$ & 50 & 14 & $\cdots$ & $\cdots$ & & $\cdots$ & \\
\hline 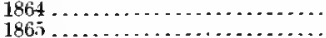 & 7,135 & & +29 & & & & & s. & $\cdots$ \\
\hline $\begin{array}{l}1865 \\
1867\end{array} \ldots \ldots \ldots$ & 4,958 & & $\begin{array}{l}+29 \\
\cdots\end{array}$ & 1 & & & & 400 & $\cdots \cdots$ \\
\hline $1868 \ldots \ldots \ldots \ldots$ & - & & & & & $\ldots$ & 300 & $\ldots \ldots \ldots$ & $\ldots \ldots$ \\
\hline$\ldots \ldots \ldots \ldots \ldots \ldots \ldots \ldots$, & $\ldots$ & 1 & bi & 114 & $\cdots \cdots$ & $\cdots \cdot$ & 650 & $\ldots \ldots \ldots$ & $\cdots .$. \\
\hline 1870192 & & $\begin{array}{c}\cdots \\
\cdots\end{array}$ & & $\cdots$ & ...... & (n....... & .500 & $\cdots$ & $\cdots$ \\
\hline 1872 & 年 & $\ldots$ & $\ldots$ & . & $\ldots \ldots \ldots$ & 8 & 150 & $\cdots$ & $\cdots$ \\
\hline$-\ldots \ldots \ldots$ & $\cdots$ & $\ldots \ldots \ldots$ & $\ldots$. & $\ldots \ldots \ldots$ & $\ldots \ldots \ldots$ & 4 & $\ldots \ldots$ & & \\
\hline $1174 \ldots \ldots \ldots \ldots \ldots \ldots \ldots \ldots$ & $\ldots$ & $\ldots$ & & & $\ldots \ldots$ & 4 & $\cdots$ & $\cdots$ & $\ldots \ldots$ \\
\hline 1875 & 1,125 & $\cdots$ & .. & & ….... & 3 & -- & $\cdots$ & $\cdots$ \\
\hline . & & & & & & & & & \\
\hline
\end{tabular}

PRIVATE FISHERY RIGHTS.

Probably the most peculiar feature of the Hawailan fisheries is the well-developed principle of private ownership of the fishes found in the open sea and bays to within a certain prescribed distance from shore. In order clearly to understand this condition of affairs it will be necessary to revert to the early history of land tenures in the islands. 
Although practically nothing is known of the history of the people for some tine after they first settled on the islands, it is probable that they lived in a patriarchal manner, followed later on by a tribal or communal system. In the meantime certain men by force of character and natural talents had become recognized as chiefs, and these men gradually usurped the rights of the common people and in time came to own everything. When a king or chief died his successor claimed the right, and exereised it in most cases, of redistributing the land amongst his own friends and adherents. This continued during the reigns of many petty chief's and kings until at last all the islands fell through conquest under the sway of Kamehameha I. The king at once divided the lands among his principal warrior chiefs, retaining, however, a considerable portion for himself. Each chief divided his lands among his inferior chiefs, who subdivided them again and again down to the lowest class of tenants. When Kamebameha II ascended the throne he wanted to redistribute the lands as of old, but during the long reign of Kamehameha I the landed interests had become so strong that he found it impossible to disturb the existing order of things, except in a few instances. Trading in lands now became common, but it was not until 1839 that the ownership of land became rested in others than the king. In the bill of rights which Kamehameha III issued on June 7 of that year, occur's the following rather vague paragraph relating to land tenures:

Protection is hereby secured to the persons of all the people, together witl their lands, their building lots, and all their property, while they conform to the laws of the kingdom, and nothing whatever shall be taken from any individual except by express provision of the laws. Whatever chief shall act perseveringly in violation of this declaration shall not longer remain a ("hief of the Hawaiian Islands, and the same shall be true of the governors, officers, and all land agents. But if anyone who is deposed should change his course and regulate his conduct by law, it shall then be in the power of the chiefs to reinstate him in the place he occupied previons to his being deposed.

It was not, however, until 1848 that land tenure was put upon a solid legal hasis by the division of the lands between the king, the chiefs, and the tenints, and vesting: the titles in each.

Each island was divided into "mokn," or districts. The subdivisions of a "moku" were "ahupuaa," which is really a unit of land in the islands. An "ahupuaa" was generally a long, narrow strip, running from the mountain to the sea, and included the mountain, the plateau, and the shore, and extended a certain distance out to sea. This distance was to the reef, if there was one; if not, to one geographical mile from shore. The owner of this portion of the sea naturally had the right to control it, so far as the fishing was concerned, the same as he did his land. When he placed a tabu on it branches of the hau tree were planted all along the shore. The people seeing this token of the tabu respected it. With the removal of the hau branches, indicating that the tabn was lifted, the people fished as they desired, subject only to the tabu days of the priest or alii, when no canoes were allowed to go out upon the water.

In accordance with a law which went into effect June 14, 1900, the fishery rights ceased on June 14, 1903 . Some of these rights are of considerable value. Close to Honolulu are two, belonging to one person, which bring in a yearly rental of $\$ 1,375$. The fisheries on Oahu are the most valuable, owing to the excellent market at Honolulu. On Kauai only a few of the fisheries are of sufficient value to be rented, these being mainly around Waimea and Hanalei. One of them rents for $\$ 200$ a year, 
while another brings in only $\$ 20$ per year. A few owners allow the fishermen the general use of their fisheries, reserving one species for themselves, as they are allowed by law to do.

Practically no effort is made to collect rent for any of the fishery rights of Hawaii. This is largely owing to the sparseness of the population and the consequent lack of markets for the fish, also somewhat to the disinclination of the people to pay rent. Some years ago the Government leased the Waiakea lands (at Hilo), including the fishing rights, to private parties. The lessees tried to collect rent for the use of the fishery, but without much success, and as the lease terminated in October, 1899, the waters became free to everybody, the new lease exempting the fishing rights.

The principal fishery right on Maui is at Kahului. The rest of them are practically free now. Merely nominal rents are exacted for the use of the fisheries around Molokai. Numerous attempts have been made by the owners to collect rent from the fishermen who frequent the waters around Lanai, but withont success.

No effort was made to secure complete data on the value of these fishery rights, as the whole matter would necessarily have to be passed upon by the courts in a short time and the owners did not care to go into the subject fully then.

For a more complete exposition of the laws concerning private fishery rights, reference is made to the preliminary report of Doctors Jordan and Evermann, pages $355-380$ of U. S. Fish Commission Report for 1901. The same paper contains a discnssion of the laws regulating the fisheries and of the measures recommended for the further protection and improvement of the industry.

\section{GENERAL STATISTICS.}

The three tables below show in a condensed form, by islands, for the year 1900 , the persons employed and their nationality, the boats, apparatus, fish ponds, and shore and accessory property used in the fisheries, and the catch br species, together with the value of same.

The island of Oahu leads all the others in almost every phase of the industry, followed by Hawaii, Maui, Kauai, Molokai, Lanai, and Niihau in the order enumerated.

The Hawaiians predominate in the fisheries, followed in the order named by the Japancse, Chinese, South Sea Islanders (people from the Gilbert and Marquesas islands), Americans, and Portuguese. The total' number of per'sons employed in 1900 was 2,345 . This does not include the persons engaged in the wholesale trade of Honolulu and Hilo, or the persons engaged in the various fish markets, as these have been shown elsewhere.

Oahu led in total investment, with $\$ 200,544$. Hawaii was a poor second, with $\$ 25,172$ of total investment. The total investment for all the islands was $\$ 272,591$.

So far as quantity of catch is concerned, akule led, but in value amaama was first. Other leading species were malolo, nlua, akn, oio, awa, moano, kawakawa, opelu, opihi, and ula. Oahu leads all the other islands in quantity and value of catch, followed by Hawaii, Maui, Kauai, Molokai, Lanai, and Niihau, in the order named. The total catch for all the islands amounted to $6,222,455$ pounds, valued at $\$ 1,083,646$. 
The malolo catch was confined almost entirely to Oahu, only 3,080 pounds being secured on Hawaii and Molokai. Oau and olepa were taken only in the fisheries of the island of Oahu. Lolohau, nohupinao, okuhekuhe, wolu, frogs, ounauna alealea and pa were taken only on Hawaii, while the carp and puuili catch was confined solely to Kauai. Ii, pakaikawale, puwalu, and loli were taken only on. Maui.

A remarkable feature of the fisheries was that but five species-aku, oio, uku, ulaula, and ulua-were taken commercially on all of the islands. It is possible that some of the others are also to be found around all of the islands, but are not sought for commercially.

Table showing, by islands and nationality, the number of persons engaged in the fisheries in 1900.

\begin{tabular}{|c|c|c|c|c|c|c|c|c|}
\hline Nationality. & Hawaii. & Kanai. & Lanai. & Maui. & Molokai. & Niihau. & Oahu. & Total. \\
\hline $\begin{array}{l}\text { Americans } \\
\text { Chinese } \\
\text { Hawaiian meil } \\
\text { Hawaiian women } \ldots \ldots \ldots \\
\text { Japanese } \\
\text { Portuguese } \\
\text { South Sea Islanders }\end{array}$ & $\begin{array}{r}2 \\
8 \\
318 \\
87 \\
134 \\
\end{array}$ & $\begin{array}{r}3 \\
34 \\
104 \\
16 \\
50 \\
1\end{array}$ & $\begin{array}{r}40 \\
6 \\
6\end{array}$ & $\begin{array}{r}1 \\
3 \\
151 \\
80 \\
37 \\
25\end{array}$ & $\begin{array}{r}20 \\
103 \\
\ldots \ldots \\
\cdots \\
2 \ldots\end{array}$ & 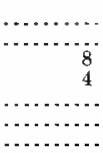 & $\begin{array}{r}173 \\
471 \\
183 \\
259 \\
2 \\
18\end{array}$ & $\begin{array}{r}6 \\
233 \\
1,195 \\
376 \\
485 \\
2 \\
43\end{array}$ \\
\hline Totel & 549 & 207 & 46 & 297 & 128 & 12 & 1,106 & 2,345 \\
\hline
\end{tabular}

Trlble showing, by islands, the boats, apparatus, fish ponds, and property used in 1900.

\begin{tabular}{|c|c|c|c|c|c|c|c|c|}
\hline \multirow{2}{*}{ ltems. } & \multicolumn{2}{|c|}{ Hawaii. } & \multicolumn{2}{|c|}{ Kauai. } & \multicolumn{2}{|c|}{ Lanai. } & \multicolumn{2}{|c|}{ Maui. } \\
\hline & No. & Value. & No. & Value. & No. & Value. & No. & Value. \\
\hline Boats. & 198 & $\$ 16,945$ & 51 & $\$ 3,215$ & 25 & $\$ 2,875$ & 80 & $\$ 7,675$ \\
\hline \multicolumn{9}{|l|}{ Apparatis: } \\
\hline Seines ...... & $\begin{array}{l}16 \\
96\end{array}$ & $\begin{array}{r}780 \\
2,585\end{array}$ & $\begin{array}{r}1 \\
14\end{array}$ & $\begin{array}{r}75 \\
103\end{array}$ & 21 & 435 & $\begin{array}{l}43 \\
28\end{array}$ & 1,550 \\
\hline Bag nets............. & $\begin{array}{r}90 \\
4\end{array}$ & $\begin{array}{r}2,080 \\
120\end{array}$ & $\begin{array}{r}14 \\
5\end{array}$ & $\begin{array}{l}103 \\
820\end{array}$ & $\cdots$ & (n) & $\begin{array}{l}28 \\
49\end{array}$ & 2,103 \\
\hline Cast nets. & 100 & 570 & 16 & 160 & & & 27 & 270 \\
\hline Dip nets ................... & 25 & 125 & 28 & 28 & $\cdots$ & $\cdots$ & 25 & 63 \\
\hline Scoop nets...... & $\cdots$. & & 10 & 10 & & & 6 & 6 \\
\hline . . . . . & & 568 & & 94 & 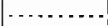 & 48 & & 124 \\
\hline$\ldots \ldots \ldots \ldots \ldots$ & $\begin{array}{l}67 \\
30\end{array}$ & $\begin{array}{r}63 \\
300\end{array}$ & 12 & 12 & $\ldots \ldots$. & $\ldots \ldots .$. & 29 & 35 \\
\hline . & 50 & & & & an. & 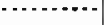 & & 390 \\
\hline Baskets (opae) $\ldots \ldots \ldots \ldots \ldots \ldots \ldots$ & 52 & 26 & 6 & 3 & .......... & ............ & (........... & $\because \ldots \ldots \ldots$ \\
\hline $\begin{array}{l}\text { Snares } \\
\text { Fish traps or pens }\end{array}$ & 8 & 3 & & $\cdots$ & $\cdots$ & $\cdots . .$. & $\ldots$. & $\ldots \ldots$ \\
\hline \multirow{2}{*}{$\begin{array}{l}\text { Fish ponds } \\
\text { Shore and accessory property } \ldots \ldots\end{array}$} & 4 & 1,200 & 6 & 5,100 & & & & \\
\hline & $\cdots$ & 1,887 & $\ldots$ & 1,144 & ........... & 120 & $\ldots$. & 2,255 \\
\hline Total & .... & 25,172 & . & 10,764 & - .......... & 3,478 & $\ldots$. & 15,171 \\
\hline \multirow{2}{*}{ Items. } & \multicolumn{2}{|c|}{ Molokai. } & \multicolumn{2}{|c|}{ Niihau. } & \multicolumn{2}{|c|}{ Oahu. } & \multicolumn{2}{|c|}{ Total. } \\
\hline & No. & Value. & No. & Value. & No. & Valne. & No. & Value. \\
\hline \multicolumn{9}{|l|}{$\begin{array}{l}\text { Boats....... } \\
\text { Apparatus: }\end{array}$} \\
\hline $\begin{array}{l}\text { Apparatus: } \\
\text { Seines... }\end{array}$ & & 250 & & & & & & \\
\hline Seines Gill nets & $\begin{array}{r}9 \\
14\end{array}$ & $\begin{array}{l}250 \\
134\end{array}$ & $\cdots$ & $\cdots \cdot$ & $\begin{array}{r}19 \\
441\end{array}$ & 1,195 & 109 & 4,285 \\
\hline Bag nets. & 9 & 1,250 & & (........... & 29 & 1,955 & $\begin{array}{r}950 \\
96\end{array}$ & $\begin{array}{r}12,393 \\
6,248\end{array}$ \\
\hline Cast nets & 43 & 430 & $\ldots$ & .......... & 83 & 1,235 & 269 & 2,675 \\
\hline Dip nets. & $\ldots$ & .......... & $\ldots$. & .......... & 68 & 304 & 146 & 520 \\
\hline Scoop nets. & & ........... & $\ldots$. & $\cdots+\cdots$ & 69 & 45 & 85 & 61 \\
\hline Lines. & & 78 & (......... & 12 & & 225 & & 1,149 \\
\hline Spears & 5 & 3 & - . n....... & ... & 51 & 53 & 164 & 166 \\
\hline Baskets (fish). & & ........... & . n. & .... & 54 & 540 & 123 & ᄂ,230 \\
\hline Baskets (opae) - & & & & ... & 47 & $2 \mathbf{I}$ & 105 & 50 \\
\hline Snares ....................... & .. & ...... & 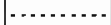 & ..... & & & 8 & \\
\hline Fish traps or pens. ..... & & & $\cdots$ & $\ldots . . .$. & 3 & 1,500 & 3 & 1,500 \\
\hline 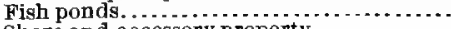 & 15 & 11,425 & $\ldots .$. & ......... & 75 & 149,050 & 100 & 166,775 \\
\hline Shore and accessory proper & & 620 & $\cdots$ & 10 & $\cdots$ & 4,560 & & 10,596 \\
\hline Total & $\ldots$. & 17,140 & ........... & 322 & & 200,544 & & 272,591 \\
\hline
\end{tabular}


Table showing, by islands and species, the tipld of the fisheries in 1900.

\begin{tabular}{|c|c|c|c|c|c|c|c|c|}
\hline \multirow{2}{*}{ Species. } & \multicolumn{2}{|c|}{ Hawaii. } & \multicolumn{2}{|c|}{ Kauai. } & \multicolumn{2}{|c|}{ Lanai. } & \multicolumn{2}{|c|}{ Maui. } \\
\hline & Lbs. & Value. & $\mathrm{bs}$ & - & Lbs. & Value. & Lbs. & Value. \\
\hline Aalaihi . & 14,430 & $\$ 746$ & & & & & 6,270 & $\$ 1,568$ \\
\hline Aawa... & 900 & 125 & & & 180 & $\$ 54$ & 1,516 & 439 \\
\hline $\begin{array}{l}\text { Aha - } \\
\text { Ahi - }\end{array}$ & & & & & 110 & 11 & 1,697 & 170 \\
\hline $\begin{array}{l}\text { Ahi } \\
\text { Aholebol }\end{array}$ & 27,484 & 1,280 & & & 73.5 & 234 & 1,000 & 199 \\
\hline $\begin{array}{l}\text { Aholebole - } \\
\text { Aku, fresh . }\end{array}$ & $\begin{array}{r}1,424 \\
179,492\end{array}$ & 212 & & & & & $\begin{array}{r}3,498 \\
82,400\end{array}$ & $\begin{array}{l}1,049 \\
7,009\end{array}$ \\
\hline ku, dried... & $\begin{array}{r}179,492 \\
21,000\end{array}$ & 19,171 & 10,892 & $\$ 2,724$ & $3 x, 0010$ & 2,111 & 82,400 & , , 00Y \\
\hline $\begin{array}{l}\text { Akule, fresh } \\
\text { Akule, dried. }\end{array}$ & 293,759 & 33,952 & 73,614 & 7,361 & 33,000 & 3,300 & 138,400 & 13,840 \\
\hline $\begin{array}{l}\text { Akule, dried ..... } \\
\text { Ama-ama (mullet }\end{array}$ & $\begin{array}{r}10,340 \\
8,593\end{array}$ & $\begin{array}{r}620 \\
2,573\end{array}$ & 60,760 & 9,115 & 12,000 & 4,800 & 24,000 & 7,000 \\
\hline Auau .......... & 15 & 1 & & & & & & \\
\hline $\begin{array}{l}\text { Awa .......... } \\
\text { A wa-awa ... }\end{array}$ & $\begin{array}{l}275 \\
400\end{array}$ & 26 & 5,109 & 511 & 345 & 35 & 1,210 & $\begin{array}{r}517 \\
, \infty 05\end{array}$ \\
\hline $\begin{array}{l}\text { A wa-awa ... } \\
\text { Awela ...... }\end{array}$ & $\begin{array}{r}400 \\
1,840\end{array}$ & $\begin{array}{r}39 \\
138\end{array}$ & & & 365 & 182 & 2,850 & 1,205 \\
\hline Aweoweo... & $\begin{array}{r}1,0+0 \\
25\end{array}$ & $\begin{array}{r}150 \\
6\end{array}$ & & & 200 & 50 & 12,590 & 3,208 \\
\hline Carp......... & & & 1,500 & 150 & & & & \\
\hline Hapí'u pú'u...... & 441 & 27 & & $\ldots$ & 213 & 21 & 2,623 & 263 \\
\hline $\begin{array}{l}\text { Hauliuli, fresh... } \\
\text { Hauliuli, dried ... }\end{array}$ & $\begin{array}{r}26,020 \\
8,200\end{array}$ & $\begin{array}{r}2,586 \\
656\end{array}$ & & & 3,800 & 760 & 6,100 & 305 \\
\hline Hibimavu ...... & 1,462 & 96 & & & 300 & 15 & 513 & 27 \\
\hline Hilu ...... & 45 & 5 & & & & & 7,296 & 876 \\
\hline Hinalea - & 1,194 & 119 & & $\ldots \ldots$ & & & 12,713 & 2,543 \\
\hline Humphumu ... & 14,410 & 967 & & & 1,400 & 112 & $\begin{array}{r}6,200 \\
10,343\end{array}$ & $\begin{array}{r}496 \\
3.384\end{array}$ \\
\hline Ineibe $\ldots . . . .$. & 8,900 & 530 & & & $b, 300$ & 1,090 & $\begin{array}{r}10,340 \\
2,546\end{array}$ & $\begin{array}{r}3,384 \\
256\end{array}$ \\
\hline 1iao... & 1,500 & 150 & & $\ldots$. & 10,625 & 170 & 10,700 & 172 \\
\hline Kabala & 40,776 & 5,907 & D. & & 5,300 & 824 & 9,686 & 1,359 \\
\hline Kaku...... & 500 & 50 & $\ldots$ & $\ldots$ & 125 & 13 & 4,050 & 507 \\
\hline Kala ............ & 4,399 & 440 & ........... & .......... & 1,300 & 52 & 11,809 & 472 \\
\hline 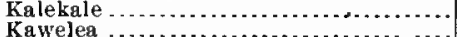 & 300 & 30 & & $\cdots$ & 500 & 50 & 1,145 & 115 \\
\hline $\begin{array}{l}\text { Kawelea... } \\
\text { Kawakawa. }\end{array}$ & 1,600 & 128 & $\ldots \ldots \ldots$ & $\cdots \cdot$ & 700 & 70 & 600 & 60 \\
\hline $\begin{array}{l}\text { Kawakawa. } \\
\text { Kole........ }\end{array}$ & 47,323 & 2,837 & $\ldots \ldots \ldots$ & $\ldots$ & 12,000 & 1,200 & 40,300 & 3,330 \\
\hline $\begin{array}{l}\text { Kole........ } \\
\text { Kuapaa ... }\end{array}$ & 12 & 1 & $\mid \ldots \ldots \ldots$ & …......... & 1,600 & 400 & 48,300 & 9,660 \\
\hline & 600 & 30 & …....... & (n......... & 1,219 & 122 & 3,200 & 320 \\
\hline Kumu . . . . & 6,300 & 588 & & & 2,714 & 1,357 & 14,400 & 4.275 \\
\hline $\begin{array}{l}\text { Kupoupol } \\
\text { Laenihi . }\end{array}$ & 148 & 15 & & & -313 & 7 & 2,125 & 850 \\
\hline & 1,200 & 118 & & 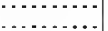 & 313 & 78 & $\begin{array}{r}3,424 \\
13\end{array}$ & $\begin{array}{r}856 \\
659\end{array}$ \\
\hline Laipala. & $\begin{array}{r}2,522 \\
10\end{array}$ & $\begin{array}{r}156 \\
1\end{array}$ & & & $\ldots$ & $\cdots \cdot$ & $\begin{array}{r}13,200 \\
3,415\end{array}$ & $\begin{array}{r}1,659 \\
854\end{array}$ \\
\hline Lauhau. & $3,33 \mathbf{I}$ & 158 & - . & & ... & & 2,008 & 402 \\
\hline Lolo- & 50 & 5 & 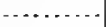 & & & & & \\
\hline Mahimahi... & $\exists, 390$ & 723 & n......... & & 1,300 & 78 & 2,705 & 163 \\
\hline$\ldots$ & 100 & 10 & $\cdots$ & $\cdots$ & 460 & 92 & 2,887 & 577 \\
\hline Maikoiko............. & 116 & 15 & $\cdots$ & $\cdots$ & $\cdots \cdots$ & $\cdots$ & 4,900 & 490 \\
\hline $\begin{array}{l}\text { Mak } \\
\text { Mlalg }\end{array}$ & $\begin{array}{r}146 \\
29\end{array}$ & $\begin{array}{r}15 \\
3\end{array}$ & & & $\ldots$. & $\cdots$ & (n....... & (n.... \\
\hline $\begin{array}{l}\text { Alalamalama .... } \\
\text { Iralolo (flying fish) }\end{array}$ & 1,280 & 112 & & & & & & \\
\hline Mlan & 50 & 4 & & & & & 2,129 & 532 \\
\hline Man & 5,089 & 382 & & & & & 6,117 & 1. 4.5 \\
\hline Man & 2,186 & 83 & & & 961 & 80 & 3,600 & 274 \\
\hline Mau & & & & & 82 & 8 & 780 & 78 \\
\hline $\begin{array}{l}\text { Mikiawa } \\
\text { Moano }\end{array}$ & $\begin{array}{r}275 \\
+60\end{array}$ & 25,163 & & & 5.800 & 1450 & $\begin{array}{r}495 \\
40 \\
200\end{array}$ & 49 \\
\hline $\begin{array}{l}\text { Moano, Iresh } \ldots \ldots \ldots \\
\text { Mloano, dried } \ldots \ldots\end{array}$ & $\begin{array}{r}143,460 \\
6,100\end{array}$ & 25,163 & & & 0,800 & & 40,200 & 10,075 \\
\hline Moi-lii & 2,000 & 300 & 12,400 & 2,480 & $400^{\circ}$ & 20 & 6,077 & 303 \\
\hline $\mathrm{Mu}$. & 25 & 3 & .......... & $\ldots \ldots$ & 244 & 61 & 200 & 50 \\
\hline Nanibu.... & 10 & 1 & & & 70 & 7 & 150 & 2 \\
\hline Nehu ... & 2,200 & 200 & .......... & $\therefore$ & 12,500 & 200 & 77,500 & 1,270 \\
\hline Nenue - - $^{-}$ & 400 & 40 & & & 1,200 & 300 & 71,200 & 17,800 \\
\hline Nibipali . . . . & $\frac{12}{24}$ & $\begin{array}{l}1 \\
2\end{array}$ & & & $\cdots$ & $\cdots$ & 1003 & 125 \\
\hline $\begin{array}{l}\text { Nohu } \\
\text { Nohupinao. }\end{array}$ & 300 & 30 & & & & & & 125 \\
\hline Nua & 385 & 19 & & & & & 1,675 & 168 \\
\hline Oio & 64,509 & 9,775 & 51,974 & 13,017 & $3,24 I$ & 810 & $11 \therefore, 377$ & 29,594 \\
\hline Okubekube & 180 & 18 & - $\ldots \ldots \ldots \ldots$ & ……… & ............ & $\cdots$ & $\cdots$ & \\
\hline$\ldots \ldots \ldots \ldots$ & 1,177 & 83 & $\ldots \ldots \ldots \ldots$ & ............ & (......... & 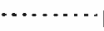 & 1,960 & 294 \\
\hline ( & $\begin{array}{r}2,100 \\
200\end{array}$ & $\begin{array}{r}210 \\
20\end{array}$ & & & .. & & & $\cdots$ \\
\hline Ono & 1,888 & 134 & & & $300^{\circ}$ & $90^{\circ}$ & 260 & 6 \\
\hline Oop & 350 & 63 & & & $\ldots$ & & & \\
\hline bue & 709 & 69 & - & & $\ldots$ & & & \\
\hline$\ldots . .$. & 1,139 & 93 & & & $\cdots$. & $\ldots .$. & $1,19^{2}$ & 478 \\
\hline 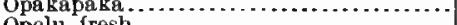 & 412 & 41 & $\cdots$ & & & $\cdots$ & & \\
\hline $\begin{array}{l}\text { Opelu, fresh } \ldots \ldots \ldots \\
\text { Opelu, dried................... }\end{array}$ & $\begin{array}{l}51,396 \\
23,100\end{array}$ & $\begin{array}{r}1,636 \\
805\end{array}$ & & & & $\cdots$ & 41,156 & 10,289 \\
\hline 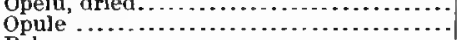 & 32 & 3 & $\ldots \ldots \ldots$ & ... & $7 \ddot{47}$ & 149 & 4.596 & 645 \\
\hline & 400 & 32 & & & & & 2,062 & 206 \\
\hline kawale ............ & & & & & $\cdots$ & $\cdots$ & 1,800 & 180 \\
\hline Pakalakala $\ldots \ldots \ldots \ldots \ldots$ & 61 & 5 & & $\ldots .$. & 665 & 67 & 542 & 54 \\
\hline Pakiki...... & 1,745 & 175 & & & 182 & 18 & 300 & 30 \\
\hline Pakii : & 10,869 & 560 & & & 845 & 127 & 11,633 & 1,745 \\
\hline $\begin{array}{l}\text { Palani... } \\
\text { Paopao.. }\end{array}$ & 5,000 & 391 & & & 1,500 & 225 & $\begin{array}{r}8,492 \\
950\end{array}$ & $\begin{array}{r}1,274 \\
95\end{array}$ \\
\hline
\end{tabular}


Table showing, by islands and species, the yield of the fisheries in 1900-Continued.

\begin{tabular}{|c|c|c|c|c|c|c|c|c|}
\hline \multirow{2}{*}{ Speèies. } & \multicolumn{2}{|c|}{ Hawaii. } & \multicolumn{2}{|c|}{ Kauai. } & \multicolumn{2}{|c|}{ Lanai. } & \multicolumn{2}{|c|}{ Maui. } \\
\hline & Lbs. & Value. & Lbs. & lue. & Lbs. & Value. & Lbs. & yalue. \\
\hline $\begin{array}{l}\text { Piha........ } \\
\text { Pilikoa . . . }\end{array}$ & $\begin{array}{r}945 \\
10\end{array}$ & $\begin{array}{r}995 \\
1\end{array}$ & & & 3,500 & $\$ 56$ & 5,585 & $\$ 88$ \\
\hline Poou ........... & 300 & 30 & & & 200 & 20 & 444 & 111 \\
\hline Poupou. & 60 & 6 & & & 200 & 20 & 260 & 26 \\
\hline Pua-ii (young mull & & & & & 8,750 & 143 & 12,500 & 200 \\
\hline Pualu $\ldots . . . . .$. & 5,595 & 428 & & & 2,182 & 546 & 2,065 & 516 \\
\hline $\begin{array}{l}\text { Puhi } \\
\text { Puwal........ }\end{array}$ & 19,710 & 1,386 & & & 5,200 & 1,300 & 35,519 & 10,109 \\
\hline $\begin{array}{l}\text { Puwalu . . . } \\
\text { Puuili . . . }\end{array}$ & & . & $\cdots \cdots, 100$ & $\cdots$ & & & $\begin{array}{c}4,700 \\
\ldots \ldots\end{array}$ & 470 \\
\hline Uha .......... & 809 & 81 & & & & & 875 & 88 \\
\hline $\mathbf{k u}$. & 13,372 & 928 & 45,722 & 25,408 & 1,800 & 90 & 11,715 & 702 \\
\hline$\ldots$ & 714 & 47 & & & 216 & 43 & & 403 \\
\hline Ulua, fresi. & $\begin{array}{r}615 \\
88,675\end{array}$ & $\begin{array}{r}61 \\
8,564\end{array}$ & $\begin{array}{l}26,552 \\
88,162\end{array}$ & $\begin{array}{l}14, \\
10\end{array}$ & $\begin{array}{r}590 \\
12,100\end{array}$ & $\begin{array}{r}148 \\
3025\end{array}$ & 90.7 & $\begin{array}{r}200 \\
14,334\end{array}$ \\
\hline Jlua, dried.. & $\begin{array}{r}88,060 \\
8,214\end{array}$ & $\begin{array}{r}8,004 \\
246\end{array}$ & 80,102 & 16 & 12,100 & 3,025 & & \\
\hline lalei. & 200 & 20 & & & & & 1,100 & 110 \\
\hline Uou & 40 & 3 & & & & & & \\
\hline $\begin{array}{l}\text { Upal } \\
\text { Uu. }\end{array}$ & 1,524 & 68 & & & 114 & 11 & 1,543 & 154 \\
\hline Uwai.... & $\begin{array}{r}34,061 \\
210\end{array}$ & $\begin{array}{r}2,136 \\
17\end{array}$ & & & 1,111 & 167 & 4,735 & 908 \\
\hline Walu & 210 & 16 & & & 700 & 70 & 1,200 & 300 \\
\hline Weke...... . & 1,000 & 100 & 11,950 & 2,820 & & & 2,400 & 360 \\
\hline $\begin{array}{l}\text { Welea ..... } \\
\text { Wolt . . . . . }\end{array}$ & $\begin{array}{l}600 \\
400\end{array}$ & 67 & …..... & r & 2,854 & 286 & 18,412 & 1,841 \\
\hline 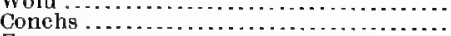 & 400 & 40 & & & & $\cdots$ & $\cdots$ & 175 \\
\hline Frogs ... & $380^{\circ}$ & $1, i$ & & & & & . & $\ldots$ \\
\hline euke.... & & & & & & & & \\
\hline $\begin{array}{l}\text { Hee (octopus) } \\
\text { Honu (turtle). }\end{array}$ & 17,416 & 3,031 & 3,000 & $T+1$ & 2,200 & 550 & 4,198 & 1,050 \\
\hline $\begin{array}{l}\text { Hon } \\
\text { Ina }\end{array}$ & 800 & 64 & & & & & 975 & $\begin{array}{r}49 \\
718\end{array}$ \\
\hline $\begin{array}{l}\text { a eggs) } . . . . . . . . \\
\text { owrie) }\end{array}$ & $\begin{array}{l}620 \\
200\end{array}$ & $\begin{array}{l}62 \\
10\end{array}$ & & & 300 & 75 & 2,870 & 718 \\
\hline (algæx) ...... & 2,150 & 188 & 397 & 81 & 720 & 180 & $\begin{array}{l}1,736 \\
2,680\end{array}$ & $\begin{array}{l}436 \\
268\end{array}$ \\
\hline bêche-de-1 & & & & & & & 1,158 & 116 \\
\hline $\begin{array}{l}\text { Mis } \\
\text { Mul }\end{array}$ & & & & & & & 150 & 23 \\
\hline $\begin{array}{l}\text { Mube } \\
\text { Naia }\end{array}$ & 30 & & & & 200 & 20 & 3,675 & 368 \\
\hline $\begin{array}{l}\text { Naia } \\
\text { Olepe }\end{array}$ & 300 & 30 & & & & $\cdots$ & - & \\
\hline $\begin{array}{l}\text { Ole } \\
\text { Our }\end{array}$ & 720 & 72 & - & & & & & \\
\hline Opa & 1,118 & 280 & 400 & 200 & & ( & 2,500 & 625 \\
\hline Opihi (limpet & 16,150 & 484 & & & & & 1,327 & 289 \\
\hline Pa. & 300 & 30 & & & & & & \\
\hline $\begin{array}{l}\text { Pap } \\
\text { Pup }\end{array}$ & 800 & 200 & 4,567 & 550 & 150 & 38 & $\begin{array}{r}1,500 \\
515\end{array}$ & $\begin{array}{r}375 \\
52\end{array}$ \\
\hline Ula (crawfis) & 15,295 & 1,758 & 622 & $156^{\circ}$ & 6,100 & 1,525 & 22,631 & 5,657 \\
\hline Wana (sea egg) . & 1,514 & 151 & $800 !$ & 160 & 600 & 150 & 8,880 & 2,220 \\
\hline Total. & $1,304,311$ & 137,734 & 403,521 & 89,993 & 212,628 & 29,853 & $1,159,117$ & 190,929 \\
\hline \multirow[t]{2}{*}{ •" } & \multicolumn{2}{|c|}{ Molokai. } & \multicolumn{2}{|c|}{ Niihau. } & \multicolumn{2}{|c|}{ Oahu. } & \multicolumn{2}{|c|}{ Totu1. } \\
\hline & Lbs. & Value. & Lbs. & Value. & Lhs. & Valne. & Lbs. & Value. \\
\hline Aalaihi. & 9.875 & 5075 & & & 3,876 & $\$ 969$ & 27,451 & $\$ 3,858$ \\
\hline Aawa... & 1,207 & 181 & & & 5, 921 & 1,481 & $9,72: 2$ & 2,280 \\
\hline A & & & & & & 283 & & 46 \\
\hline ho & 60 & $\begin{array}{r}60 \\
275\end{array}$ & & & 1 & 24 & & 2, \\
\hline $\begin{array}{l}\text { lole... } \\
\text { resh.. }\end{array}$ & 1,834 & $\begin{array}{r}275 \\
3.996\end{array}$ & 380 & $\$ 95$ & 12 , & 3,155 & & 4.691 \\
\hline $\begin{array}{ll}A k \\
A k\end{array}$ & 33,300 & 3,996 & & $\$ 90$ & 56,589 & 6,277 & & $\begin{array}{r}41,383 \\
840\end{array}$ \\
\hline fresh & 33,912 & 3,391 & & & 266,643 & 19,828 & 830 & $\begin{array}{r}81,672 \\
81,60\end{array}$ \\
\hline dried & & & & & & & 10,340 & 620 \\
\hline m & 323 & $\begin{array}{r}65 \\
\end{array}$ & & & & & 323 & 65 \\
\hline $\mathrm{ama}(\mathrm{m}$ & 112,514 & 28,154 & $\ldots$ & & 503,794 & 125,920 & 721,661 & 177,562 \\
\hline . & - & 555 & - $\cdots \cdots$ & 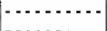 & & & & \\
\hline . & 219 & 593 & & & $\begin{array}{r}233,877 \\
2,083\end{array}$ & $\begin{array}{r}58,139 \\
522\end{array}$ & & 59,783 \\
\hline (. & 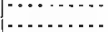 & . & 3,100 & 465 & 2,085 & 522 & & $\begin{array}{r}1,968 \\
465\end{array}$ \\
\hline . & & & & & 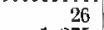 & -1 & & 144 \\
\hline weo.. & 1,275 & 446. & & & 1,375 & 590 & 15 & 4,300 \\
\hline - - - - & & $\cdots$ & | & $\ldots$ & & & & 150 \\
\hline . & $\cdots$ & $\cdots$ & 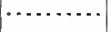 & & $\begin{array}{l}3,988 \\
193\end{array}$ & 1,396 & 3,98 & 1,396 \\
\hline ב. & ( & & 800 & $\cdots$ & 193 & 48 & & 48 \\
\hline ... & & & 000 & & $\ddot{54}$ & 607 & & $\begin{array}{l}120 \\
607\end{array}$ \\
\hline . . . . . & 502 & 50 & $\cdots$ & ........ & 1,890 & 237 & 5,669 & 598 \\
\hline ......... & ........ & .... & $\ldots .$. & & & & 35,920 & 3,651 \\
\hline , dries & & & .. & & & $\because$ & & 656 \\
\hline & & & 1 & & 1,790 & 17 & & 317 \\
\hline$\ldots \ldots$ & & & & & 350 & 12 & & 1,005 \\
\hline 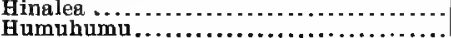 & $\begin{array}{l}1,696 \\
7,191\end{array}$ & $\begin{array}{l}170 \\
575\end{array}$ & - & $\cdots$ & $\begin{array}{r}3,143 \\
14,876\end{array}$ & $\begin{array}{l}472 \\
893\end{array}$ & & $\begin{array}{l}3,304 \\
3,043\end{array}$ \\
\hline ....... & & & & & & 895 & 44,077 & 3,043 \\
\hline
\end{tabular}


Table showing, by islands and species, the yield of the fisheries in 1900-Continued.

\begin{tabular}{|c|c|c|c|c|c|c|c|c|}
\hline \multirow{2}{*}{ Species. } & \multicolumn{2}{|c|}{ Molokai. } & \multicolumn{2}{|c|}{ Niihau. } & \multicolumn{2}{|c|}{ Oabu. } & \multicolumn{2}{|c|}{ Total. } \\
\hline & Lbs. & Value. & Lbs & e. & Lhs. & Value. & Lbs. & Value. \\
\hline Ibeihe. & 3,240 & $\$ 810$ & & & 2,017 & 8404 & 29,300 & $\$ 6,718$ \\
\hline Iiao...... & & & & & & & $\begin{aligned} & 2,546 \\
& 22, \times 25\end{aligned}$ & $\begin{array}{l}256 \\
492\end{array}$ \\
\hline Kahala & $\ddot{2}, 148$ & 215 & & & 3,915 & 781 & 61,825 & 9,086 \\
\hline Kaku. . & & & & & 1,007 & 215 & 5,742 & 725 \\
\hline Kala. & 7,421 & 594 & & & 13,766 & 688 & 38,695 & 2,246 \\
\hline $\begin{array}{l}\text { Kalekale. } \\
\text { Kawelea. }\end{array}$ & & & & & & & $\begin{array}{l}1,945 \\
2,900\end{array}$ & $\begin{array}{l}195 \\
258\end{array}$ \\
\hline Kawakawa & 13,674 & 1,367 & & & 78,135 & 15,627 & 191,432 & 24,361 \\
\hline Koae -... & 643 & 96 & & & & & 643 & 96 \\
\hline $\begin{array}{l}\text { Kole.......... } \\
\text { Kuapaa ... }\end{array}$ & & & & & & 1 & 49,918 & 10,062 \\
\hline $\begin{array}{l}\text { Kuapaa ... } \\
\text { Kumu ..... }\end{array}$ & 11,631 & 1,744 & & & 20925 & 5.207 & $\begin{array}{r}5,019 \\
55,070\end{array}$ & $\begin{array}{l}472 \\
171\end{array}$ \\
\hline Kupoupo & 851 & 213 & & & $\begin{array}{r}20,920 \\
219\end{array}$ & $\begin{array}{r}0,201 \\
55\end{array}$ & $\begin{array}{r}50,910 \\
3,343\end{array}$ & $\begin{array}{r}13,181 \\
1,133\end{array}$ \\
\hline Kupipi... & & & & & 139 & 16 & 139 & 16 \\
\hline Laenihi - & & & & & 1,680 & 421 & 6,617 & 1,473 \\
\hline Laí . ..... & 1,634 & 163 & & & 368 & 37 & $\begin{array}{r}17,790 \\
3,4055\end{array}$ & $\begin{array}{l}1,995 \\
855\end{array}$ \\
\hline Lauhau ... & 2,065 & 310 & & & $110^{\circ}$ & ii & 7,514 & 881 \\
\hline Lolo-oau. & & & & & & & 50 & \\
\hline Mahimabi & 1,895 & 114 & & & 3,344 & 502 & 18,634 & 1,580 \\
\hline $\begin{array}{l}\text { Maiii . } \\
\text { Majkoi }\end{array}$ & 400 & & & & $\begin{array}{l}131 \\
122\end{array}$ & 20 & 3.576 & $\begin{array}{l}699 \\
561\end{array}$ \\
\hline $\mathrm{Ma}$ & 429 & 40 & & & $\begin{array}{l}122 \\
195\end{array}$ & $\begin{array}{l}15 \\
49\end{array}$ & $\begin{array}{r}n .391 \\
3+1\end{array}$ & 64 \\
\hline Mal & & & & & & 1 & 32 & $\begin{array}{r}03 \\
4\end{array}$ \\
\hline Malolo (Ayi & 800 & -200 & & & 571,002 & $14 \geq, 773$ & 573,042 & 143,085 \\
\hline Maxo & & & & & 309 & & 2,488 & 614 \\
\hline Manini & 4,067 & 767 & & & 10,005 & 2,484 & $25,52 x$ & 5,111 \\
\hline Mano (shark) & 596 & 30 & & & 11,490 & 219 & 18,833 & 686 \\
\hline $\begin{array}{l}\text { Maupaau } \\
\text { Mikiawa }\end{array}$ & 391 & 39 & & & 842 & 211 & 2,001 & $\begin{array}{r}86 \\
322\end{array}$ \\
\hline Moano, fresh & 5,497 & 825 & - & & 18,042 & 4,510 & 212,999 & 42,028 \\
\hline , dried. & . & & & & & & 6,100 & 305 \\
\hline $\begin{array}{l}\text { Moi- } \\
\text { Mu. }\end{array}$ & & & & & 12,642 & 1,265 & 33,519 & 4,368 \\
\hline Nanihu. & & & & & $\mathrm{3} 2$ & 9 & $\begin{array}{l}501 \\
230\end{array}$ & $\begin{array}{r}123 \\
10\end{array}$ \\
\hline Nehu... & 300 & & & & & & 92,500 & 1,696 \\
\hline Nen & & & & & 2,260 & 339 & 75,060 & 18,479 \\
\hline $\mathrm{Nil}$ & & & & & 42 & 11 & 54 & 12 \\
\hline Nohu..... & 1,006 & 151 & & & 195 & 47 & 1,828 & 325 \\
\hline $\begin{array}{l}\text { Nohur } \\
\text { Nunu. }\end{array}$ & 2051 & & & & 1001 & & 300 & $\begin{array}{r}30 \\
495\end{array}$ \\
\hline Oau ... & 2,001 & 200 & & & $\begin{array}{r}1,021 \\
319\end{array}$ & $\begin{array}{r}102 \\
80\end{array}$ & $\begin{array}{r}5,132 \\
319\end{array}$ & $\begin{array}{r}495 \\
80\end{array}$ \\
\hline Oio - - & 36,000 & 9,000 & 7,200 & $\$ 1,800$ & 40,322 & 10,080 & 321,623 & 74,076 \\
\hline Okv & & & $\cdots$ & & . & & 180 & 18 \\
\hline Olale ........ & 1,612 & 161 & & $\cdots$ & 11 & 3 & 4,760 & $5+1$ \\
\hline $\begin{array}{l}\text { Omakaha } . . . . . . . . . \\
\text { Omjlu }\end{array}$ & ….... & . & & $\cdots$ & $\begin{array}{r}3,627 \\
19\end{array}$ & 906 & 5,727 & 1,116 \\
\hline $\begin{array}{l}\text { Onilu } \ldots . . . \\
\text { Ono } \ldots . . . . .\end{array}$ & $1, \overline{17}$ & 176 & $\ldots .$. & & 12,276 & 1,841 & 12,476 & 1,861 \\
\hline (n) & $\begin{array}{r}1,1,1 \\
\ldots \ldots\end{array}$ & 176 & ,.... & $\cdots$ & 560 & 56 & 4,179 & 462 \\
\hline $\begin{array}{l}\text { Oopu } \\
\text { Oopuhue }\end{array}$ & (2) & $\cdots$ & & & $\begin{array}{r}3,813 \\
130\end{array}$ & 577 & 4,193 & 630 \\
\hline Oopukai......... & 694 & 139 & $\ldots$ & $\cdots$ & $\begin{array}{l}130 \\
1,948\end{array}$ & $\begin{array}{r}20 \\
486\end{array}$ & $\begin{array}{r}839 \\
4 \quad 973\end{array}$ & $\begin{array}{r}89 \\
196\end{array}$ \\
\hline Opakapaka...... & & & & & 6,056 & 606 & $\begin{array}{l}4,970 \\
6,468\end{array}$ & $\begin{array}{r}1,196 \\
647\end{array}$ \\
\hline Opelu, fresh - & 13,842 & 2,768 & & & 9,361 & 2,340 & 115,695 & 17,033 \\
\hline$d$ & & & & & & & 23,100 & 805 \\
\hline le .......... & 1,739 & 174 & & & 969 & 243 & 8,083 & 1,214 \\
\hline Paka & 1,303 & 139 & & & $\cdots \cdots$ & ..... & 3,765 & 368 \\
\hline Paks & $\cdots$ & & & & is & (2) & 1,800 & 180 \\
\hline kala.... & & $\cdots$ & & & 10 & 1 & 1,278 & 127 \\
\hline Pakjki... & 4129 & 413 & & & 1370 & & 2,227 & 223 \\
\hline Pakii.... & $\begin{array}{l}4,129 \\
9,700\end{array}$ & $\begin{array}{r}413 \\
1.455\end{array}$ & & & 4,372 & 1,580 & 31,848 & 4,375 \\
\hline 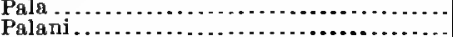 & 2,540 & $\begin{array}{r}1,400 \\
381\end{array}$ & $\cdots$ & & & & 9,700 & $1,4 \div 5$ \\
\hline 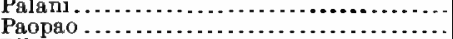 & 745 & $\begin{array}{r}751 \\
75\end{array}$ & 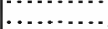 & $\cdots$ & 2,604 & 551 & 20,136 & 2,822 \\
\hline & & & & & (n. & $\cdots$ & 1,695 & 170 \\
\hline 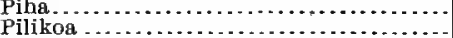 & . & $\ldots$ & 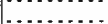 & & 212 & & 10,030 & 239 \\
\hline $\begin{array}{l}\text { Pilikoa } \\
\text { Poou .. }\end{array}$ & & & & & & 32 & 222 & 33 \\
\hline${ }_{-\ldots} \ldots \ldots \ldots \ldots$ & ... & & & & 20 & 31 & 1,150 & 192 \\
\hline (young soullet) $\ldots . . .$. & & $\cdots$ & & & 26 & 2 & 546 & 54 \\
\hline Pua-ii (young soullet) .... & & & & & & & 21,250 & 340 \\
\hline$\ldots \ldots \ldots \ldots \ldots$ & & & & & 1,876 & 402 & 11,718 & 1,892 \\
\hline Puhi & 8,064 & 968 & & & 6,582 & 658 & 75,075 & 14,421 \\
\hline Puwalu $\ldots \ldots \ldots \ldots \ldots \ldots \ldots \ldots \ldots$ & $\cdots \cdots$ & $\cdots$ & & $\cdots$ & $\ldots \ldots \ldots$ & $\cdots \cdots$ & 4,700 & 470 \\
\hline 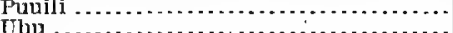 & & & & s & 10.50 & & 5,100 & 158 \\
\hline 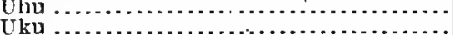 & 2,617 & 131 & 4,400 & 1,100 & 14,605 & & 17,863 & 2,837 \\
\hline (n) & 616 & 123 & & & $\begin{array}{r}14,003 \\
97\end{array}$ & 1,459 & 94,231 & 29,818 \\
\hline , & & & 1,200 & & 11.98 & 10 & 3,658 & 626 \\
\hline $\begin{array}{l}\text { Ulaula. } \\
\text { Ulua, fre }\end{array}$ & 16.692 & 3,338 & & & 11,236 & 2,809 & 41,768 & 18,155 \\
\hline $\begin{array}{l}\text { Ulua, fre } \\
\text { Ulua, dri }\end{array}$ & 10,092 & 0,858 & 5,100 & 510 & 324,272 & 67,630 & 625,526 & 107,397 \\
\hline 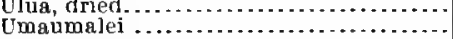 & & $0.2-2$ & 0,100 & 510 & $\cdots \cdots$ & & 13,314 & 756 \\
\hline 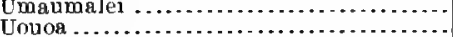 & & $\cdots$ & & 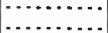 & 40 & 0 & 1,340 & 134 \\
\hline 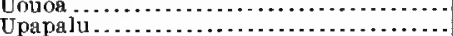 & & & & & & & 48 & \\
\hline \begin{tabular}{|}
$\mathbf{U}$ \\
$\mathbf{U}$
\end{tabular} & 1,090 & 131 & . & $\begin{array}{l}\cdots \\
\cdots\end{array}$ & $\begin{array}{r}1,983 \\
33,154\end{array}$ & 297 & 5,478 & 561 \\
\hline Uu & & & & ............ & 33,154 & 8,288 & 74,151 & 11,630 \\
\hline
\end{tabular}


Table showing, by islands and species, the yield of the fisheries in 1900--Continued.

\begin{tabular}{|c|c|c|c|c|c|c|c|c|}
\hline \multirow{2}{*}{ Species. } & \multicolumn{2}{|c|}{ Molokai. } & \multicolumn{2}{|c|}{ Nibau. } & \multicolumn{2}{|c|}{ Cahu. } & \multicolumn{2}{|c|}{ Total. } \\
\hline & Lbs. & Value. & Los. & Value. & Lbs. & Value. & Lbs. & Value. \\
\hline Uwau & & & & & 185 & $\$ 46$ & 395 & $\$ 63$ \\
\hline Walu. & & & & & & & 1,900 & 370 \\
\hline Weke...... & 2,878 & $\$ 345$ & 600 & $\$ 120^{\circ}$ & 70,713 & 17,675 & 89,541 & 21,420 \\
\hline Welea ......... & 2,422 & 242 & ..... & $\$ 120$ & 316 & 64 & 24,604 & 2,493 \\
\hline Wolu .......... & $\ldots \ldots . .$. & $\ldots$. & $\ldots$ & & $\ldots$ & $\ldots$ & 400 & 40 \\
\hline Conchs ....... & $\ldots \ldots \ldots$ & $\cdots$ & $=$ & & 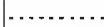 & 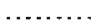 & 700 & 175 \\
\hline Frogs... & . & . & & & . . & & 380 & 190 \\
\hline euke....... & & & $\ldots$ & & 50 & 13 & 60 & 14 \\
\hline Hee (octopus) .. & 1,700 & 340 & & & 26,085 & 6,521 & 54,499 & 12,242 \\
\hline 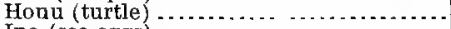 & 150 & 9 & $\ldots$ & $\ldots$ & 2,745 & 357 & 4,670 & 479 \\
\hline Ina (sea eggs) $\ldots \ldots \ldots \ldots \ldots \ldots \ldots \ldots \ldots$ & $\cdots \cdots$ & $\cdots$ & & & & & 3,790 & 855 \\
\hline Leho (cowrie)........... & $\ldots \ldots . . .$. & $\ldots$ & & & - & & 1,936 & 445 \\
\hline Limu (a]gæ) & & & 145 & 15 & 36,672 & 4,584 & 42,764 & 5,316 \\
\hline Loli (bêehe-de-mer) .... . & & $\cdots$ & & & r & & 1,158 & 116 \\
\hline shellfish. & & & & & & & 150 & 23 \\
\hline Muhee (squid) ......... & $\ldots$ & & $\ldots$ & $\ldots$ & 24 & & 3,899 & 392 \\
\hline Naia (porpoise) ... & $\cdots$ & $\cdots$ & $-\cdots$ & & 60 & 2 & 360 & 32 \\
\hline Olepa (clam) .......... & & & . & & 327 & 49 & 327 & 49 \\
\hline Ounauna alealea .............. & . & & $\cdots$ & -. & $\ldots . . .$. & $\ldots$. & 720 & 7 \\
\hline Opae (shrimp) ... & & & & & 3,694 & 797 & 7,712 & 1,902 \\
\hline Opihi (limpet) $\ldots \ldots \ldots \ldots \ldots \ldots \ldots$ & 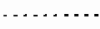 & & 250 & 65 & 129,500 & 19,425 & 147,227 & 20,263 \\
\hline Pá & & $\cdots$ & .... & & 8,670 & 2,168 & $\begin{array}{r}300 \\
15,687\end{array}$ & $\begin{array}{r}30 \\
3,331\end{array}$ \\
\hline Pupu (sea snail). .......... & & & & & & & 515 & \\
\hline Ula (crawfish)..... & & & 1,200 & 300 & 85,334 & 8,551 & 131,182 & 17,947 \\
\hline 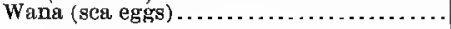 & & $\cdots$ & 250 & 63 & 4,587 & 1,147 & 16,631 & 3,891 \\
\hline Total & 376,255 & 67,599 & 29,525 & 5,623 & $2,737,198$ & 561,915 & $6,222,455$ & $1,083,646$ \\
\hline
\end{tabular}






